

Produced under direction of the U.S.

Department of the Interior Office of Insular Affairs by the National Renewable Energy Laboratory (NREL) under Interagency Agreement IAG-101773 and Task No WFF4.3000.

\section{Guam Initial Technical Assessment Report} lan Baring-Gould, Misty Conrad, Scott Haase, Eliza Hotchkiss, and Peter McNutt
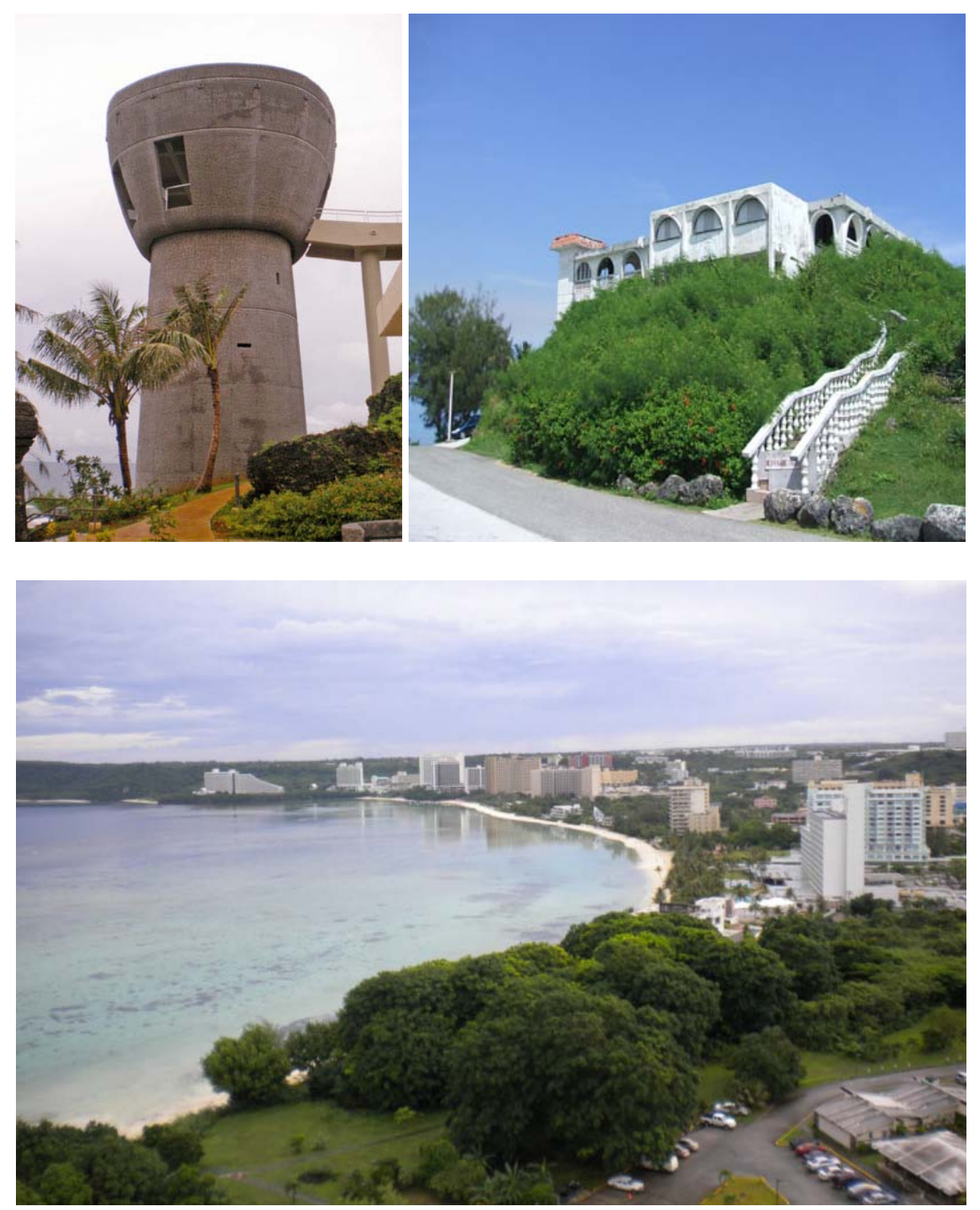

Technical Report

NREL/TP-7A40-50580

April 2011 


\title{
Guam Initial Technical Assessment Report
}

\author{
lan Baring-Gould, Misty Conrad, Scott Haase, Eliza Hotchkiss, Peter McNutt
}

Disclaimer: This manuscript has been authored by employees of the Alliance for Sustainable Energy, LLC ("Alliance") under Contract No. DE-AC36-08G028308 with the U.S. Department of Energy (“DOE”).

Neither Alliance, DOE, the United States government nor any agency thereof, nor any of their employees, makes any warranty, express or implied, or assumes any legal liability or responsibility for the accuracy, completeness, or usefulness of any information, apparatus, product, or process disclosed in this manuscript, or represents that its use would not infringe privately owned rights. Reference herein to any specific commercial product, process, or service by trade name, trademark, manufacturer, or otherwise does not necessarily constitute or imply its endorsement, recommendation, or favoring by Alliance, DOE or the United States Government or any agency thereof. The views and opinions of authors expressed herein do not necessarily state or reflect those of Alliance, DOE or the United States government or any agency thereof.

Cover photo credit: NREL/PIX 18630, 18629, 18590

NREL is a national laboratory of the U.S. Department of Energy, Office of Energy Efficiency \& Renewable Energy, operated by the Alliance for Sustainable Energy. LLC.

Contract No. DE-AC36-08G028308
Technical Report NREL/TP-7A40-50580

April 2011 


\section{Contacts and Team Members}

\section{Department of the Interior}

Tony Babauta

Assistant Secretary

Office of Insular Affairs

U.S. Department of Interior

Washington, DC 20240

Office Phone: (202) 208-6816

Nikolao Pula

Director

Office of Insular Affairs

U.S. Department of Interior

Washington, DC 20240

Office Phone: (202) 208-6816

E-mail: nikolao_pula@ios.doi.gov

National Renewable Energy Laboratory

Misty Dawn Conrad

Senior Project Leader II

Office Phone: (303) 384-7467

E-mail: misty.conrad@nrel.gov

Ian Baring-Gould

Technology Deployment Manager

Office Phone: (303) 384-7021/(202) 586-9136

E-mail: ian.baring-gould@nrel.gov
Charlene Leizear

Director of Technical Assistance

Office of Insular Affairs

U.S. Department of Interior

Washington, DC 20240

Office Phone: (202) 208-3239

E-mail: charlene_leizear@ios.doi.gov

Angie Williams

Guam Desk Officer

Office of Insular Affairs

U.S. Department of the Interior

Washington, DC 20240

Office Phone: (202) 208-3003

E-mail: angela_williams@ios.doi.gov

Scott Haase

Senior Engineer

Office Phone: (303) 275-3057

E-mail: scott.haase@nrel.gov

Eliza Hotchkiss

Analyst III

Office Phone: (303) 475-6786

E-mail: eliza.hotchkiss@nrel.gov

Peter McNutt

Senior Engineer

Office Phone: (303) 384-6767

E-mail: peter.mcnutt@nrel.gov 


\section{Acknowledgments}

The National Renewable Energy Laboratory (NREL) thanks the U.S. Department of Interior's Office of Insular Affairs (OIA) for providing funding for this effort. In particular, NREL would like to thank Assistant Secretary Tony Babauta for his vision and leadership in moving this energy assessment and planning process forward in the Pacific Territories.

NREL would like to acknowledge the valuable assistance of the OIA staff: Director Nikolao Pula, Angela Williams, and Charlene Leizear.

In addition, NREL and the entire assessment team are grateful to the following facility managers, directors, engineers, and operators for their generous assistance and cooperation during the NREL team's site visit to Guam:

- Guam Power Authority: Joaquin Flores, John J. Cruz, Francis J. Iriarte, Jennifer G. Sablan, Melinda R. Camacho, Louis Camacho

- University of Guam: President Robert Underwood, Ph.D.; Samuel Walker; Louise M. Toves; Bruce Best; Michael L. Bevacqua, Ph.D.

- Guam Community College: President Mary Okada

- Department of Defense: Captain Peter Lynch, Regional Engineer, Joint Region Marianas and Commanding Officer, NAVFAC Marianas; Kevin D. Evans, Joint Region Marianas, NAVFAC Marianas, Supervisory Energy Manager; Derek Briggs, Naval Base Guam, Energy Manager

- United States Department of Agriculture: Joseph Diego, John Lawrence, Mark Defley

- A special thank you to Mayor Melissa Savares for taking the time to show the NREL team around Dededo

- Guam Environmental Protection Agency (EPA)\Energy Office: Ivan Quinata, Administrator

- US EPA Region 9: Michael Wolfram, Michael Mann

- Guam Energy Office: Director Lorilee Chrisostomo; Staff: David Menlo, Charlyne Guerrero, Richard Diego, Steven Mun 


\section{Abstract}

On March 1, 2010, Assistant Secretary Tony Babauta from the Department of Interior's (DOI) Office of Insular Affairs (OIA), invited Governors Felix Camacho (Guam), Benigno Fitial (Commonwealth of the Northern Mariana Islands), and Togiola Tulafono (American Samoa) and their staff to meet with Senior Principals at the National Renewable Energy Laboratory (NREL) for discussions on ways to improve energy efficiency and increase the deployment of renewable energy technologies in the U.S. Pacific Territories. This meeting brought together major stakeholders to learn and understand the importance of developing a comprehensive strategic plan for implementing energy efficiency measures and renewable energy technologies.

For several generations, dependence on fossil fuels and the burden of oil prices have been a major concern. The urgency has never been more prevelant than today. With unstable oil prices, the volatility of supply and future military build-up plans on Guam, energy issues have become a high priority for the island. Succinctly, energy security is critical to Guam's future economic development and sustainability.

Under an interagency agreement, funded by OIA, NREL was tasked to deliver technical assistance to the island of Guam by conducting an island initial technical assessment that would lay out energy consumption and production data and establish a baseline. This assessment will be used to conduct future analysis and studies by NREL that will estimate energy efficiency and renewable energy potential for the island of Guam.

NREL provided an interdisciplinary team to cover each relevant technical area for energy assessments, system recovery, and upgrades. Experts in the following disciplines traveled to Guam for on-island site assessments October 11-15, 2010:

- Integrated Wind-Diesel Generation

- Transmission and Distribution

- Energy Efficiency and Building Technologies

- Solar Technologies

- Biomass and Waste-to-Energy

- Geothermal.

In addition to the above core disciplines, team capabilities also included expertise in program analysis, project financing, policy, and energy project, planning and Energy Committee facilitation.

The intent was to provide Guam with various scenarios and approaches to deploying cost effective energy efficiency and renewable energy technologies in a manner that will meet Guam's energy objectives. The information compiled in this energy assessment will be used as input in the development of a strategic plan. 


\section{Executive Summary}

This document is an initial technical energy assessment for Guam, the first of many steps in developing a comprehensive energy strategy. The project plan for Guam includes three main objectives:

\section{Assist in establishing an Energy Task Force}

2. Publish an initial island assessment report to establish a baseline and identify energy efficiency and renewable energy opportunities

3. Support the Energy Task Force in developing a draft energy strategic plan that will provide Guam with various scenarios and approaches to deploying cost effective energy efficiency and renewable energy technologies in a manner that will meet the island's objectives in reducing dependency on imported fossil fuels.

This report meets the second objective of establishing a baseline and identifying opportunities. A baseline gathers various data points to establish a reference against which progress can be measured. It allows comparison across sectors through trend identification and provides a tool for goal setting and measuring success of those goals. Before a baseline can be established, a methodology is developed.

The information compiled in this assessment will be used as input in the development of a strategic plan to meet the third project objective. This process sets the procedures and rationale that underlie the study.

This document summarizes data collected regarding energy production, consumption, and efficiencies, and discusses renewable energy and energy efficiency technology potential and current barriers and opportunities. The opportunities highlighted in this report can be used to formulate an energy plan. The following table highlights current energy efficiency and renewable energy opportunities designating them a low, medium, or high priority for impact.

Table 1. Energy Efficiency and Renewable Energy Opportunities and Potential Impacts

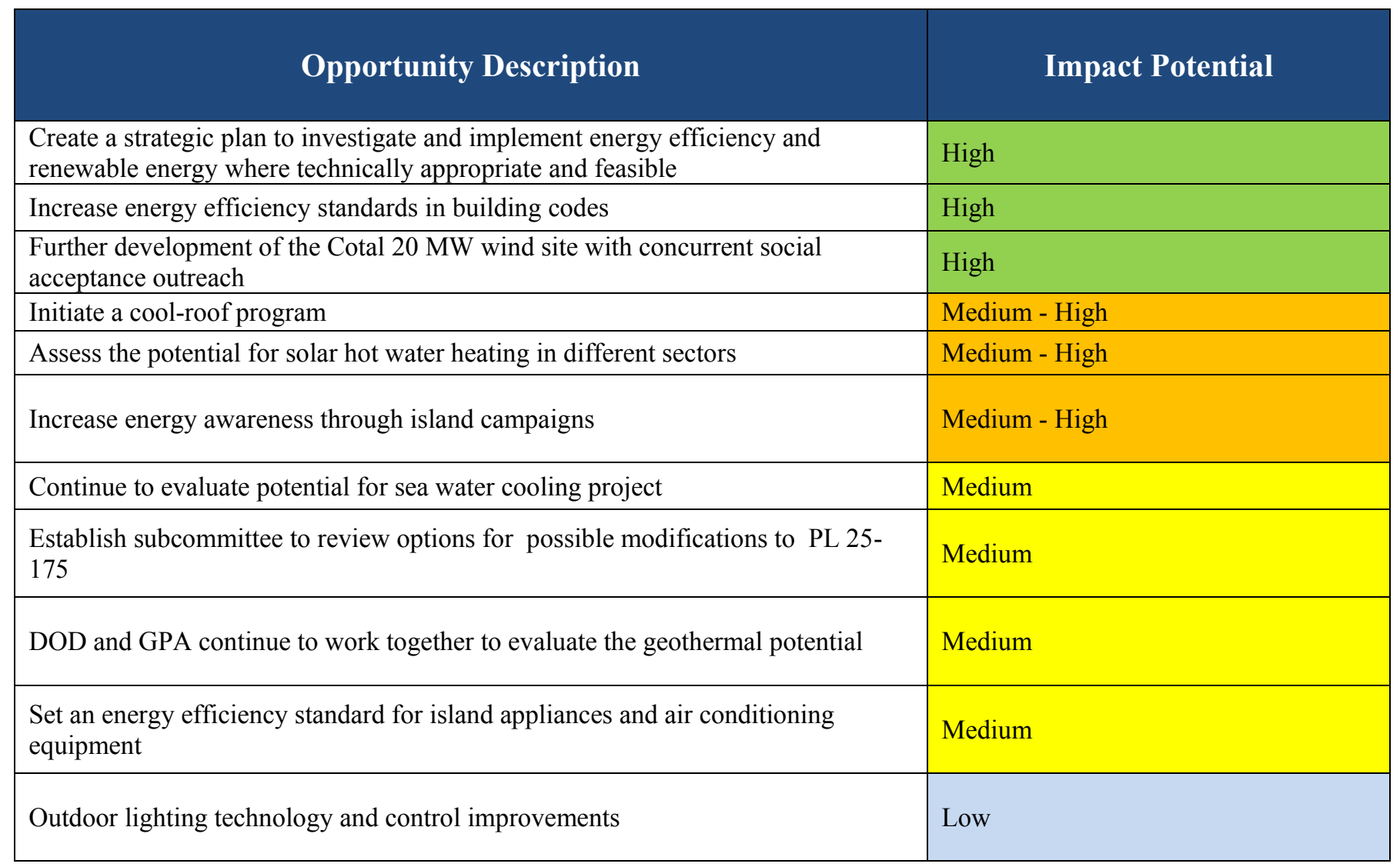


Also within this report is a section that outlines barriers, possible next steps, and potential for technical assistance. Detailed technical information can be found in the appendices for further reference. 


\section{Acronyms and Abbreviations}

ASHRAE American Society of Heating, Refrigerating and Air-Conditioning Engineers

bbl billion barrels

Btu British thermal unit

C\&D $\quad$ construction and demolition

CIA Central Intelligence Agency

CT Combustion Turbine

DEM Digitial Elevation Model

DOD Department of Defense

DOE Department of Energy

DOI Department of Interior

EIS Environmental Impact Statement

EMD Electro-Motive Diesel

EPA Environmental Protection Agency

F Farenheight

FY Fiscal Year

GE General Electric

GM General Motors

GPA Guam Power Authority

GRPP Guam Resource Recovery Partners

GWA Guam Waterworks Authority

GWh gigawatt hour

HECO Hawaiian Electric Company

HP horsepower

IBM Izu-Bonin-Mariana

IECC International Energy Conservation Code

IFB Invitation fore Multi-step Bid 


$\begin{array}{ll}\text { IPP } & \text { Independent Power Producers } \\ \text { IRP } & \text { Integrated Resource Plan } \\ \text { km } & \text { kilometers } \\ \text { kV } & \text { kilovolt } \\ \text { kVA } & \text { kilovolt-ampere } \\ \text { kW } & \text { kilowatt } \\ \text { kWh } & \text { kilowatt hour } \\ \text { lb } & \text { pound } \\ \text { LED } & \text { Light-Emitting Diode } \\ \text { LEED } & \text { Leadership in Energy and Environmental Design } \\ \text { LFG } & \text { landfill gas } \\ \text { LIDAR } & \text { Light Detection and Ranging } \\ \text { m } & \text { meters } \\ \text { MECO } & \text { Maui Electric Company } \\ \text { MGD } & \text { millon gallons per day } \\ \text { mi } & \text { miles } \\ \text { m/s } & \text { meters per second } \\ \text { MMBtu } & \text { million British thermal units } \\ \text { MSW } & \text { municipal solid waste } \\ \text { MW } & \text { megawatt } \\ \text { MWh } & \text { megawatt hours } \\ \text { NAVFAC } & \text { Naval Facilities Engineering Command } \\ \text { NDWTP } & \text { Northern District Wasterwater Treatment Plant } \\ \text { NOx } & \text { nitric oxide } \\ \text { NRCS } & \text { National Resources Conservation Service } \\ \text { NREL } & \text { National Renewable Energy Laboratory } \\ \text { OIA } & \text { Office of Insular Affairs } \\ \text { Public Law }\end{array}$




$\begin{array}{ll}\text { PMC } & \text { Performance Management Contract } \\ \text { PUC } & \text { Public Utilities Commission } \\ \text { RFO } & \text { residual fuel oil } \\ \text { RFP } & \text { Request for Proposal } \\ \text { RPM } & \text { revolutions per minute } \\ \text { RPS } & \text { Renewable Portfolio Standard } \\ \text { SARs } & \text { Severe Acute Respiratory Syndrome } \\ \text { Sf } & \text { square foot } \\ \text { SWMD } & \text { solid waste management district } \\ \text { USDA } & \text { U.S. Department of Agriculture } \\ \text { WTE } & \text { waste-to-energy }\end{array}$




\section{Table of Contents}

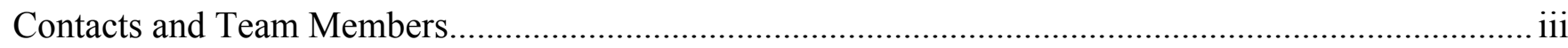



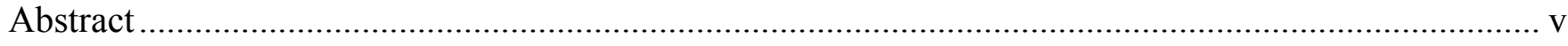

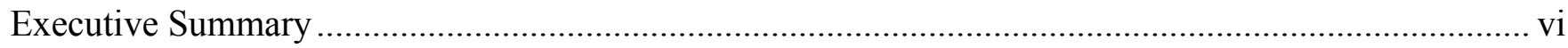

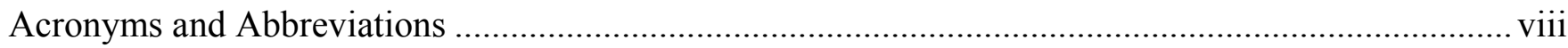

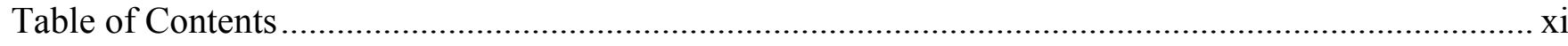

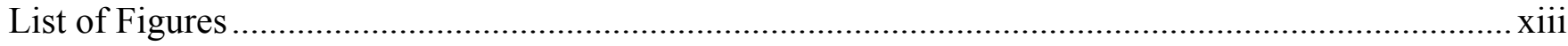

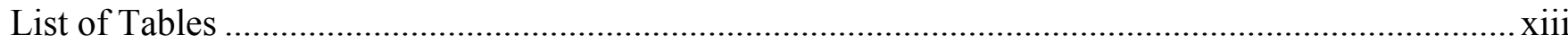

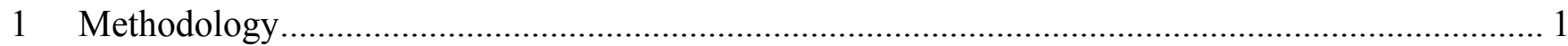

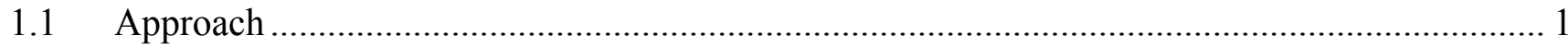

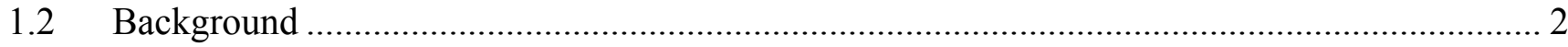





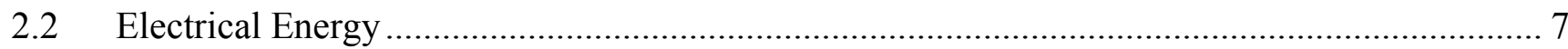

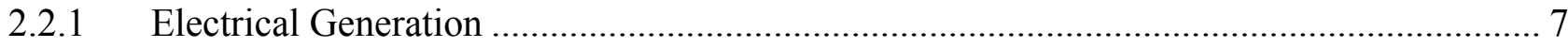

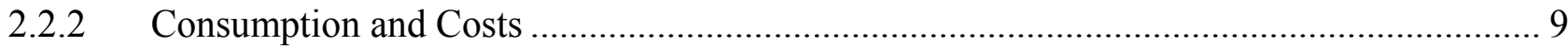



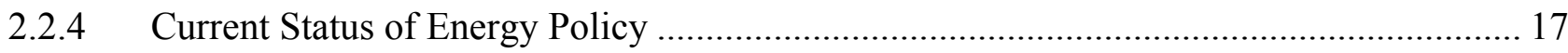

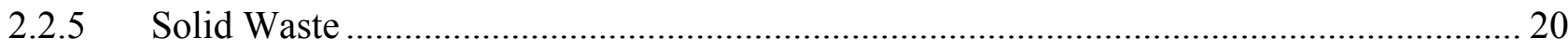

3 Energy Efficiency and Renewable Energy Opportunities.............................................................. 25

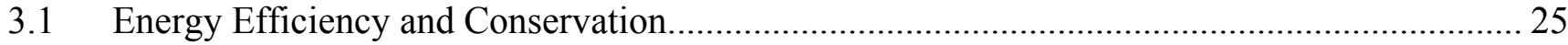

3.1.1 Raise Island Energy Awareness for Conservation............................................................ 25

3.1.2 Establish a Cool-Roof Program to Improve Efficiency ..................................................... 26

3.1.3 Review and Improve Energy Efficiency Standards to Improve Efficiency.......................... 27

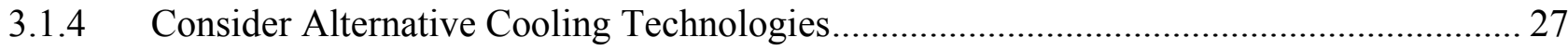

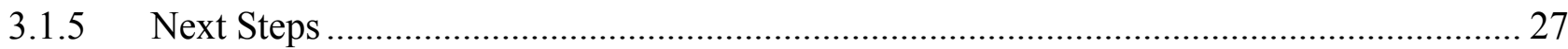

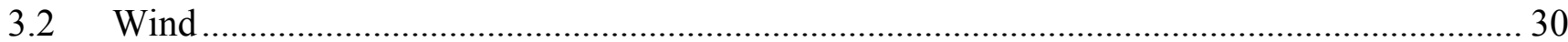

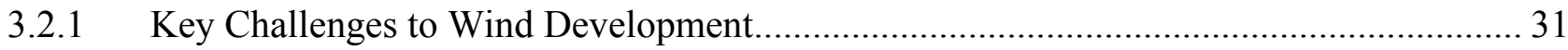

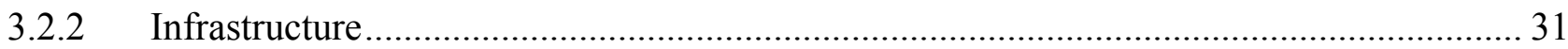



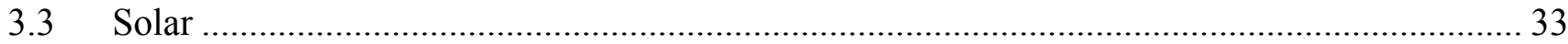

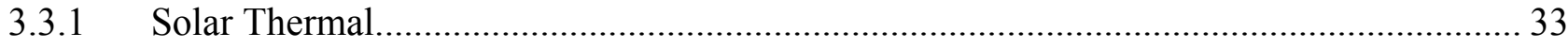

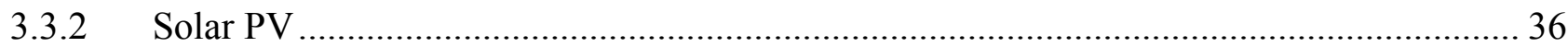

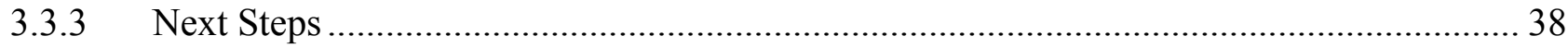

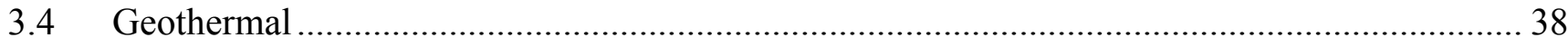






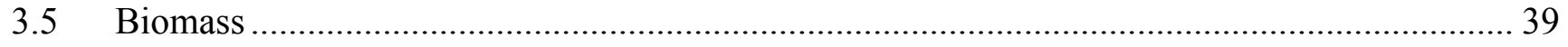

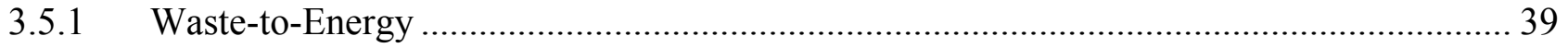

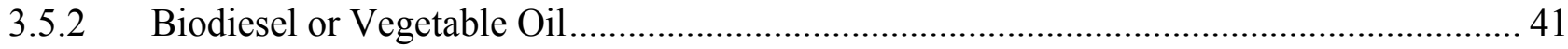

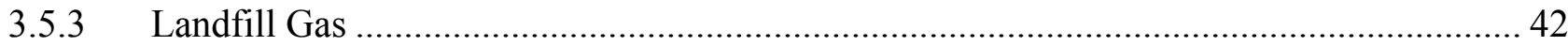



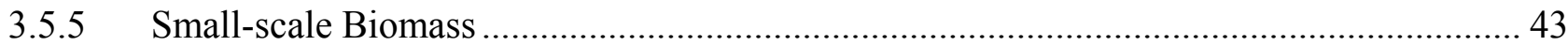

3.5.6 Production of Dedicated Biomass Feedstocks ............................................................... 43

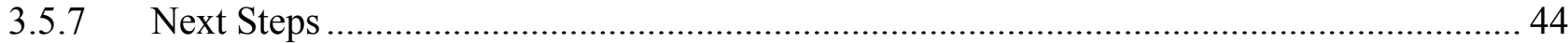

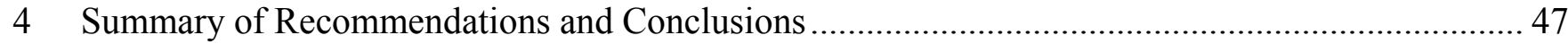

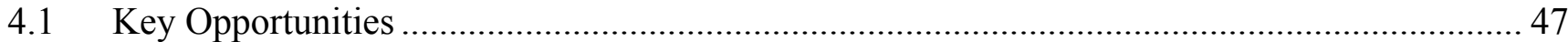

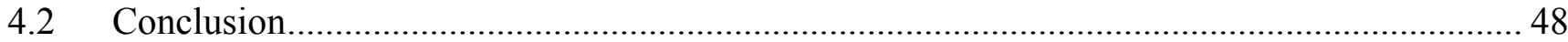

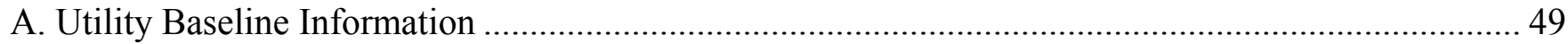

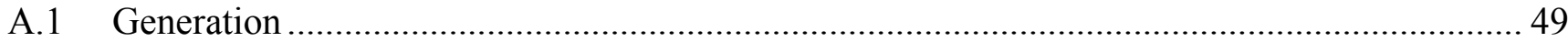

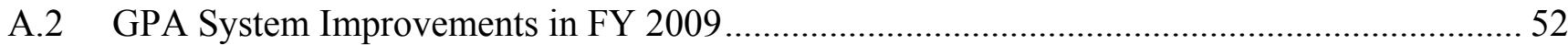

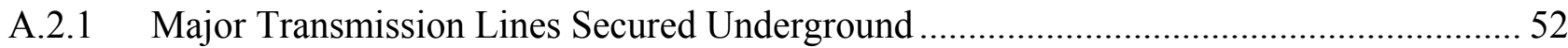

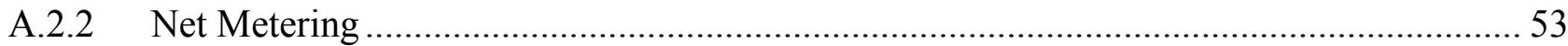

A.2.3 Groundwork Laid for Pre-Paid Meters ..................................................................... 53

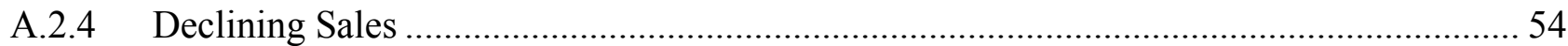

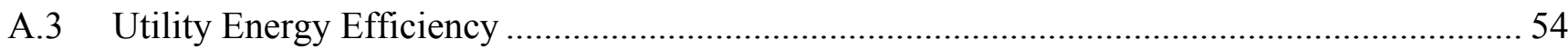



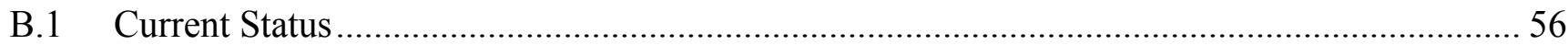

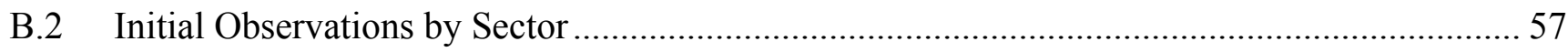

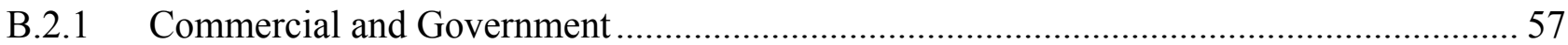

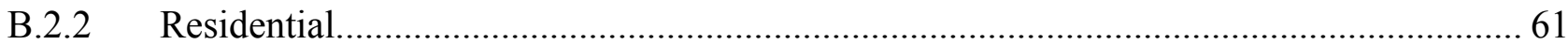

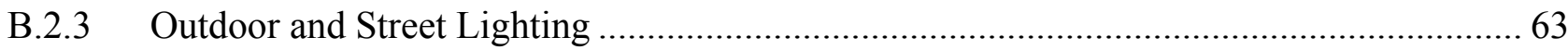

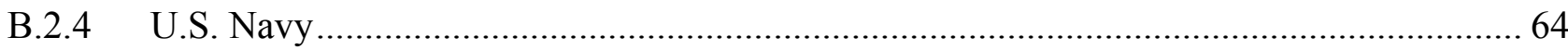

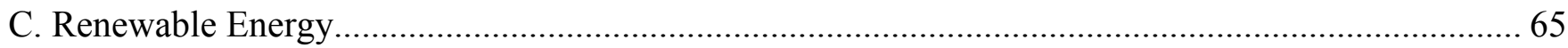

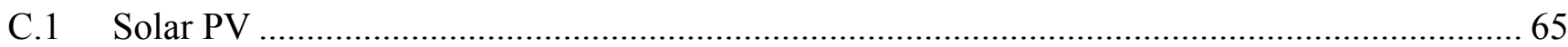

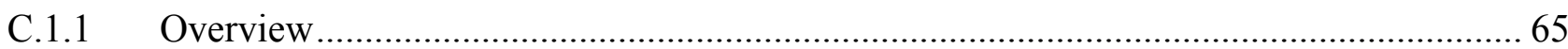

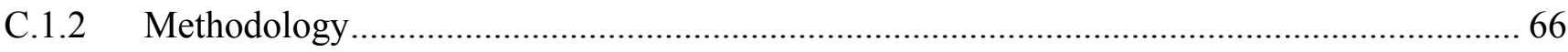





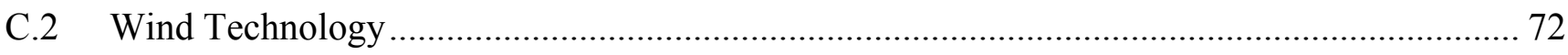

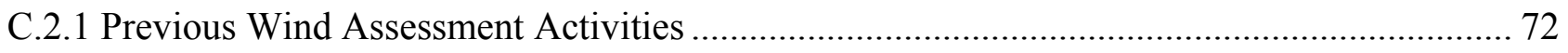




\section{List of Figures}

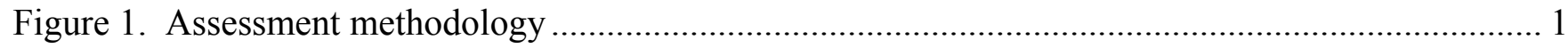

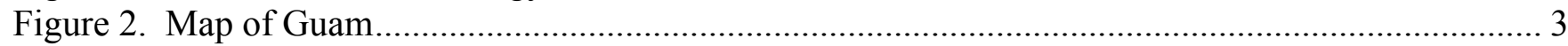



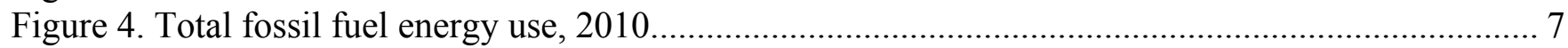

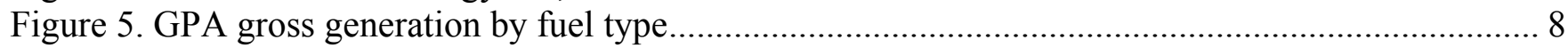

Figure 6. GPA gross electricity production, fuel consumption and overall system heat rate..................... 9

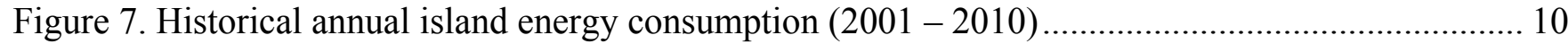

Figure 8. Overall GPA system hourly load profiles (March 1, 2009 - February 28, 2010)..................... 11

Figure 9. Guam energy consumption by sector $(2001-2010$ average $)$................................................. 12

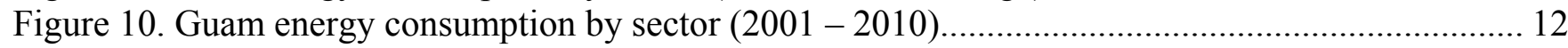

Figure 11. Guam Community College's LEED-registered building under construction ........................... 13

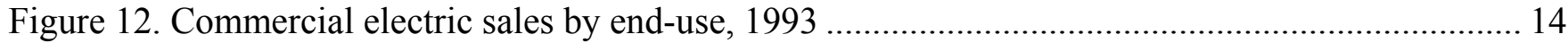

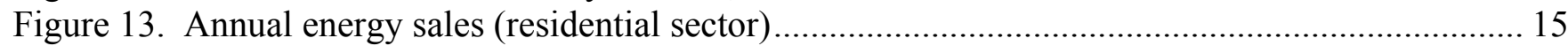

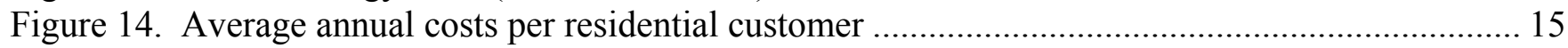

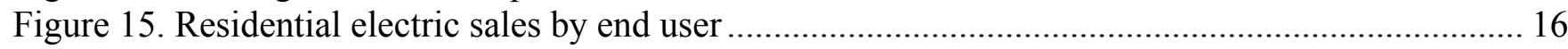

Figure 16. Guam government sector energy consumption by percentage of total energy consumption.. 17

Figure 17. October 2010 waste characterization study (limited sample)................................................. 22

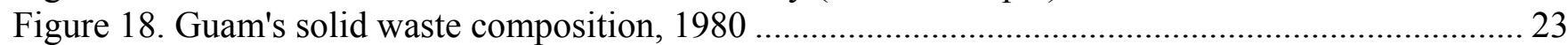

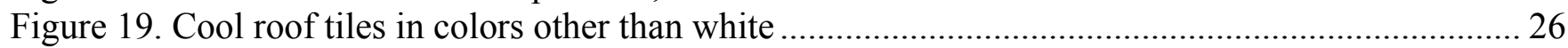

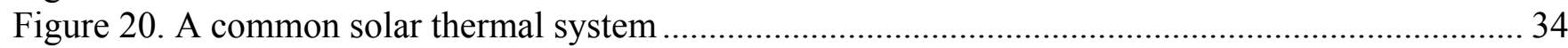

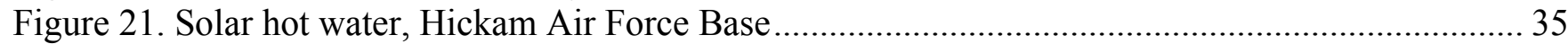

Figure 22. U.S. Coast Guard housing, Honolulu, Hawaii ......................................................................... 35

Figure 23. GPA transmission system map with potential solar and wind locations marked...................... 37

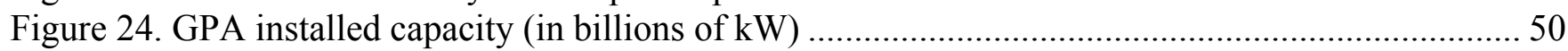

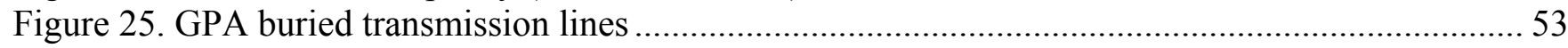



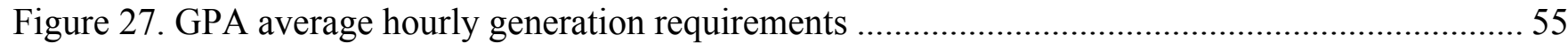

Figure 28. Recovery Act funding allocated to energy efficiency measures on Guam (in millions of U.S.

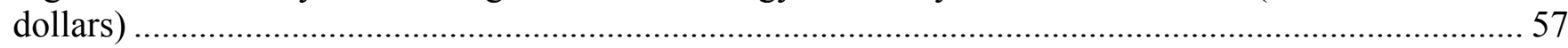

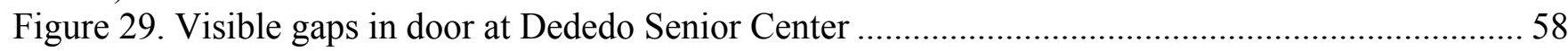



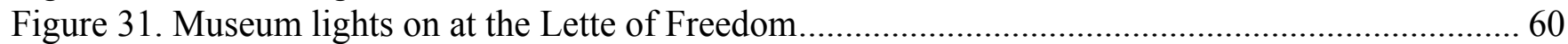

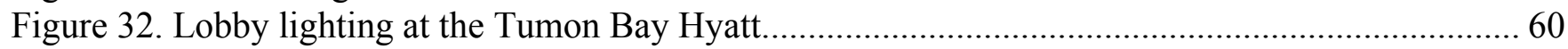

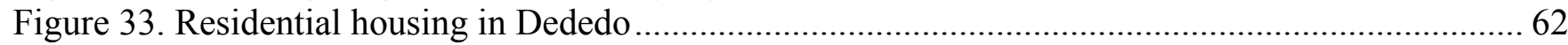

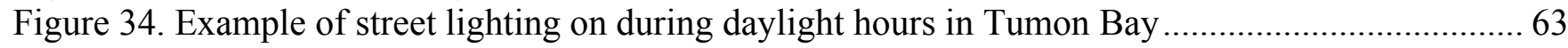

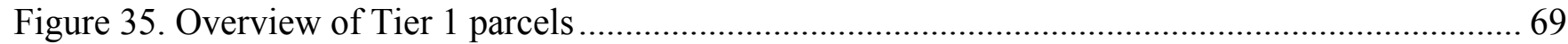

Figure 36. Boxplot of mean wind speed at $60 \mathrm{~m}$ for Guam Naval Ordnance (10/1/2008 - 9/30/2010) .. 74

Figure 37. Power density rose for Guam Naval Ordnance (10/1/2008 - 9/30/2010) ................................ 74

\section{List of Tables}

Table 1. Energy Efficiency and Renewable Energy Opportunities and Potential Impacts ........................ vi

Table 2. Estimated Additional Military and Associated Population in 2017 ............................................ 4

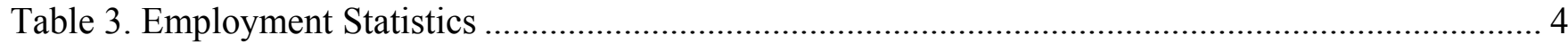

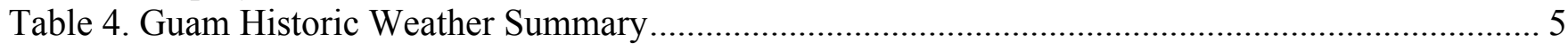

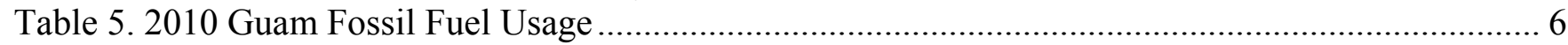

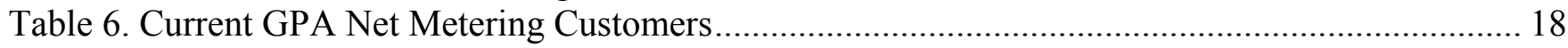



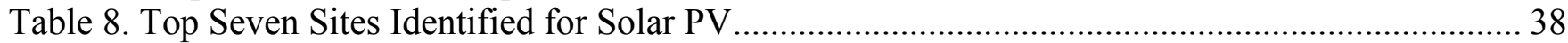




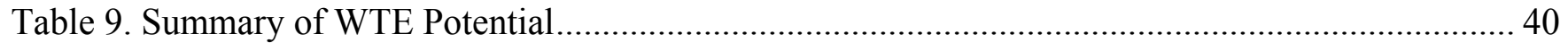



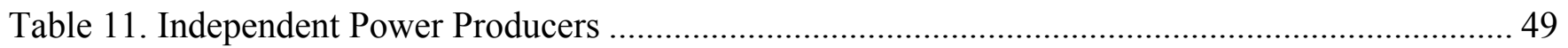

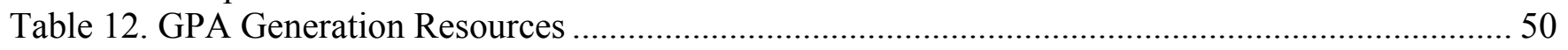

Table 13. Dededo Senior Center Indoor Temperature and Related Costs ........................................ 58

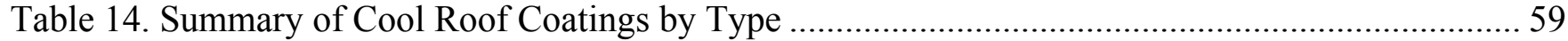

Table 15. Recommended Efficient Lamp Types by Space Use..................................................... 61

Table 16. Recommended Efficient Lamp Types for Outdoor and Street Lighting ..............................63

Table 17. Top Seven Sites Identified for Solar PV ................................................................ 70

Table 18. Estimated Total Population Increase on Guam from Off-Island (Direct, Indirect, and Induced) 


\section{Methodology}

To clarify the National Renewable Energy Laboratory's (NREL) team's understanding of the project, the approach and background information used for the assessment have been outlined in Sections 1.1 and 1.2 .

\subsection{Approach}

Establishing the parameters of a study provides focus for the assessment team. Certain topic areas, such as transportation, are considered important to overall energy strategies, however were not considered within the Guam assessment due to budget constraints and the priority of targeting energy efficiency and renewable energy technologies.

Each assessment begins with a background study to understand the site demographics and geography. Human and physical geography impact energy consumption and the success of implementation of renewable energy projects, therefore this information is essential to the types of recommendations made.

Data collection and researching previous studies allows the assessment team to understand what the current baseline consumption is and what recommendations have been made in the past. The data collection process coincides with a site visit to interview stakeholders and survey the options to be included within the assessment. After the site visit, information is analyzed and opportunities are identified.

The graphic in Figure 1 illustrates the major components of NREL's assessment methodology.



Figure 1. Assessment methodology 
It is essential to look at the energy picture of Guam holistically. The Department of Defense (DOD) has considerable representation on-island, accounting for approximately $21 \%$ to $22 \%$ of Guam's energy consumption. With an impending military build-up, concerns surrounding energy use are receiving increased attention. An extensive understanding of the relationship between Guam's military installations and the civilian side of the island is necessary to establish energy efficiency and renewable energy baselines from a whole island approach. NREL's assessment team concentrated on baseline factors that accounted for DOD presence.

This report focuses on island-wide utility generation and consumption patterns, not specific DOD energy efficiency and renewable energy activities. DOD has its own internal goals for renewable energy and energy efficiency. As DOD seeks to meet these goals, there may be impacts on the operations and economics of Guam Power Authority (GPA) - it is important for DOD and GPA to continue to work together to understand these impacts and seek to develop win-win solutions.

There are many energy efficiency and renewable energy technologies on the market today. Included within this study's parameters are mature technologies that are considered prime time and bankable. There are other technologies that Guam may want to investigate for future study, but for the basis of this study, technologies included had the following criteria:

- Commercial availability

- Tested and demonstrated

- Carry warranty

- Service and parts available

- Ready for immediate deployment

- Sound investment

- Financing available from private sector organizations.

This assessment focuses on clean energy technologies. There is varied opinion on what falls under this purview. For the purposes of this study, commercial clean energy technologies were identified under the current NREL portfolio, including wind, solar, biomass, energy efficiency, and geothermal. NREL did not assess opportunities associated with ocean thermal energy conversion, off-shore wind, marine hydrokinetic, nuclear, coal, or liquefied natural gas.

This document summarizes data collected regarding energy production, consumption, and efficiencies, and discusses renewable energy and energy efficiency technology potential and current policy barriers and opportunities.

\subsection{Background}

Guam is an island in the North Pacific Ocean ( $13^{\circ}$ north and $144^{\circ}$ east). Guam is an unincorporated territory of the United States under the jurisdiction of the Office of Insular Affairs (OIA). Guam has a total land area of $544 \mathrm{~km}^{2}\left(210 \mathrm{mi}^{2}\right)$ with $125 \mathrm{~km}(130 \mathrm{mi})$ of coastline, making it the largest and southernmost island in the Mariana Archipelago. Figure 2 provides a basic map of Guam ${ }^{1}$.

\footnotetext{
${ }^{1}$ http://coris.noaa.gov/about/eco_essays/guam/geography.html.
} 




Figure 2. Map of Guam

Source: NOAA

The island is volcanic, has coral reefs, a coralline limestone plateau, which is the source of most of the island's fresh water; and cliffs along the coast and mountains in the south of the island (the highest point is Mount Lamlam at $406 \mathrm{~m}$ ). Permanent crops cover $18 \%$ of the island. Natural hazards include squalls during the rainy season, typhoons (between June-December), and invasive predators like the brown tree snake that decimated the local bird population and the Rhinoceros beetle, which is destroying the coconut palm.

In 2000 , the island's population was $154,805^{2}$ and the 2010 estimate is $180,865^{3}$, spread throughout about 20 villages. In 2000, the five largest villages were Dededo (42,980), Yigo (19,474), Tamuning $(18,012)$, Mangilao $(13,313)$, and Barrigada $(8,652)$. According to the OIA website, the population in 2010 was 178,000 , which is slightly lower than the Central Intelligence Agency estimates of 180,865. The value of 180,865 is assumed in this report when making any per capita estimates.

\footnotetext{
${ }^{2}$ Government of Guam website: http://www.spc.int/prism/country/gu/stats/Census/Census.htm.

${ }^{3}$ CIA World Factbook: https://www.cia.gov/library/publications/the-world-factbook/geos/gq.html.
} 
With the planned military buildup (relocating troops from Okinawa to Guam) these figures are expected to grow fairly significantly, but are always changing. There are many factors to consider; funding availability, infrastructure and construction readiness, 2011 earthquake and tsunami in Japan, etc. Table 148 in Appendix C provides additional information provided from the Environmental Impact Statement (EIS).

The military build-up will impact the electricity consumption and generation needs on Guam. As the surge of military activity increases, economical impacts are expected. The estimated expected population is summarized in Table $2 .{ }^{4}$

Table 2. Estimated Additional Military and Associated Population in 2017

\begin{tabular}{|c|c|c|c|c|}
\hline $\begin{array}{c}\text { Marines } \\
\text { moving } \\
\text { from } \\
\text { Okinawa }\end{array}$ & Dependents & $\begin{array}{c}\text { Civilian } \\
\text { Employees }\end{array}$ & $\begin{array}{c}\text { Temporary } \\
\text { Workers }\end{array}$ & $\begin{array}{c}\text { Estimated } \\
\text { Cost }\end{array}$ \\
\hline 8,600 & $\sim 9,000$ & 6,000 & $\sim 20,000$ & $\begin{array}{c}\$ 10.27 \\
\text { billion }\end{array}$ \\
\hline
\end{tabular}

Cultural dynamics often impact energy consumption as well. Guam is rich with diversity; ethnic groups include native Chamorro (37.1\%), Filipino (26.3\%), Pacific Islanders (11.3\%), white (6.9\%), other Asian (6.3\%), other ethnic origins (2.3\%), and mixed ethnicities $(9.8 \%){ }^{5}$ The predominant religion is Roman Catholic. Languages include English (38\%), Chamorro (22\%), Filipino (22\%), Pacific island languages (6\%), and Asian languages (7\%). Guam has a literacy rate of 99\%.

The economy is driven mostly by military and tourism; the tourism industry has grown since the 1980 s due to a push to attract Japanese tourists. With a total of 1-1.2 million tourists a year, Japanese tourists made up $76 \%$ of tourists in 2007 with direct tourist spending being $\$ 1.2$ billion. The basic breakdown of total payroll employment and percentage of total is summarized in Table 3.

Table 3. Employment Statistics ${ }^{6}$

\begin{tabular}{|l|l|}
\hline Total payroll employment (2007) & 60,350 \\
\hline Private sector employment & 45,320 \\
\hline Government employment & 15,030 \\
\hline Private sector employment as a \% of total & $75.1 \%$ \\
\hline Government employment as a \% of total & $24.9 \%$ \\
\hline Unemployment rate & $11.4 \%$ \\
\hline Private sector average weekly earning & $\$ 411.55$ \\
\hline Government of Guam average weekly earnings & $\$ 737.48$ \\
\hline
\end{tabular}

Guam has a tropical marine climate that is warm and humid with little seasonal temperature variation, illustrated in Figure 3. Climate impacts the energy consumption in a specific geographic region.

\footnotetext{
${ }^{4}$ OIA website: http://www.doi.gov/oia/Islandpages/gumpage.htm\#pagetop.

${ }^{5}$ OIA website: http://www.doi.gov/oia/Islandpages/gumpage.htm\#pagetop.

${ }^{6}$ Ibid.
} 




Figure 3. War in the Pacific Park Source: NREL/PIX 18625

The U.S. Department of Energy (DOE) has issued maps of various climate zones based on temperature and humidity. Guam's climate is tropical marine with the dry season between January-June and the rainy season between July-December. Yearly average temperatures range between $76^{\circ} \mathrm{F}$ and $86^{\circ} \mathrm{F}$ and average annual precipitation is 86 inches. Table 4 summarizes the historic weather on the island over the past 47 years.

Table 4. Guam Historic Weather Summary ${ }^{7}$

\section{Agana, Guam}

Elevation: 246 feet

Latitude: $1329 \mathrm{~N}$ Longitude: 144 48E

\section{-}

Average Temperature

${ }^{\circ} \mathrm{F} \mid$\begin{tabular}{l|l|l|l|l|l|l|l|l|l|l|l|l|l|l} 
YEAR & Jan. & Feb. & Mar. & Apr. & May & Jun. & Jul. & Aug. & Sep. & Oct. & Nov. & Dec. \\
80 & 80 & 81 & 82 & 82 & 83 & 82 & 82 & 82 & 82 & 82 & 81
\end{tabular}

Average High Temperature

\begin{tabular}{l|l|l|l|l|l|l|l|l|l|l|l|l|l|l}
${ }^{\circ} \mathrm{F}$ & $\begin{array}{l}\text { YEAR } \\
86\end{array}$ & $\mathbf{8 a n}$. & Feb. & Mar. & Apr. & May & Jun. & Jul. & Aug. & Sep. & Oct. & Nov. & Dec. \\
85 & 86 & 87 & 87 & 88 & 87 & 87 & 87 & 87 & 87 & 86
\end{tabular}

Average Low Temperature

\begin{tabular}{l|l|l|l|l|l|l|l|l|l|l|l|l|l|l|l}
${ }^{\circ} \mathrm{F}$ & $\begin{array}{l}\text { YEAR } \\
76\end{array}$ & Jan. & Feb. & Mar. & Apr. & May & Jun. & Jul. & Aug. & Sep. & Oct. & Nov. & Dec. \\
74 & 75 & 76 & 77 & 77 & 76 & 76 & 76 & 76 & 77 & 76
\end{tabular}

Highest Recorded Temperature

\begin{tabular}{r|l|l|l|l|l|l|l|l|l|l|l|l|l}
${ }^{\circ} \mathrm{F}$ & $\begin{array}{l}\text { YEAR } \\
96\end{array}$ & 94 & Jan. & Feb. & Mar. & Apr. & May & Jun. & Jul. & Aug. & Sep. & Oct. & Nov. \\
93 & 93 & 96 & 94 & 95 & 95 & 93 & 93 & 93 & 92 & 91
\end{tabular}

Lowest Recorded Temperature

\begin{tabular}{l|l|l|l|l|l|l|l|l|l|l|l|l|l|l}
${ }^{\circ} \mathrm{F}$ & $\begin{array}{l}\text { YEAR } \\
65\end{array}$ & 67 & 65 & 66 & 68 & 70 & 70 & 70 & 70 & 70 & 67 & 68 & 68
\end{tabular}

Average Precipitation

in. \begin{tabular}{|l|l|l|l|l|l|l|l|l|l|l|l|l|} 
YEAR & Jan. & Feb. & Mar. & Apr. & May & Jun. & Jul. & Aug. & Sep. & Oct. & Nov. & Dec. \\
86.8 & 4.4 & 3.2 & 2.5 & 3.4 & 5.3 & 5.6 & 9.6 & 13.4 & 13.1 & 12.5 & 8.5 & 5.1
\end{tabular}

\footnotetext{
${ }^{7}$ Weather Base, Guam: http://www.weatherbase.com/weather/weather.php3?s=021219\&refer. Accessed January 7, 2011.
} 


\section{Establishing a Baseline}

Following a review of the natural and cultural influences, site assessments incorporate historical energy consumption data to establish the baseline. This section summarizes observations from electrical generation, end-use energy consumption and costs, and solid waste management. Additional details are provided in the appendices.

\subsection{Overall Fossil Fuel Energy Use}

With the exception of a few small renewable energy projects, Guam is $100 \%$ dependent on fossil fuels for meeting its energy supply needs. The primary sectors that consume fossil fuels in Guam are:

- Production of electricity

- Transportation

- Water heating and self-generation by the commercial sector (primarily hotels)

- Propane for home cooking and small commercial operations.

NREL obtained information on fossil fuel consumption for electricity production, transportation, and propane use by consumers. We did not attempt to locate data on consumption by hotels or small commercial sectors. In 2010, GPA consumed nearly 2.9 million barrels of fossil fuel $(120,519,396$ gallons) for power generation. ${ }^{8}$ The Guam Energy Office collects data on fuel sales, including jet fuel and consumer propane. ${ }^{9}$

In 2010, 109 million gallons of motor fuel were sold, including gasoline, diesel, and jet fuel. Note the motor fuel data compiled by the Guam Energy Office does not include shipping to Guam, air transport and freight and DOD.

In 2010, Guam used 230 million gallons of fossil fuel, or over 1,270 gallons per year for every man, woman, and child living on the island. This value can serve as the primary baseline for setting fossil fuel reduction targets and against which future program impacts can be measured. Table 5 shows the breakdown by end use, and Figure 4 shows these values graphically.

Table 5. 2010 Guam Fossil Fuel Usage

\begin{tabular}{|l|r|}
\hline \multicolumn{1}{|c|}{ End Use } & \multicolumn{1}{c|}{ Gallons/year } \\
\hline Gasoline & $46,262,100$ \\
\hline No 2 Diesel & $14,105,600$ \\
\hline Jet & $44,812,200$ \\
\hline Propane - Consumer & $4,305,500$ \\
\hline GPA & $120,519,396$ \\
\hline Total Fuel Used & $\mathbf{2 3 0 , 0 0 4 , 7 9 6}$ \\
\hline Population & 180,865 \\
\hline Fuel use per capita & $\mathbf{1 , 2 7 2}$ \\
\hline
\end{tabular}

\footnotetext{
${ }^{8}$ Internal data provided to NREL by GPA.

${ }^{9}$ Source: Guam Energy Office. Spreadsheet provided by David Meno based on retail sales by fuel distributors (Shell, Mobil and 76).
} 


\section{Guam Energy Usage 2010 \\ (\% by use based on gallons consumed)}



Figure 4. Total fossil fuel energy use, 2010

Source: GPA

\subsection{Electrical Energy}

\subsubsection{Electrical Generation}

GPA is a full service electric utility serving about 46,000 customers. GPA owns and manages 663 miles of transmission and distribution lines and 29 substations throughout the island. Electricity is delivered through a transmission and distribution grid consisting of a combination of $115 \mathrm{kV}, 34.5 \mathrm{kV}$, and 13.8 $\mathrm{kV}$ lines. Its generation capacity is $552 \mathrm{MW}$ with total energy production of $1,854 \mathrm{GWh}$ (FY 2009). The highest peak system demand was 281.5 MW in June 2001.

GPA's generation includes 181 MW from Independent Power Producers. The generation mix is $33 \%$ steam turbine, $30 \%$ slow-speed diesel, $26 \%$ combustion turbine, and $10 \%$ fast-track diesels. GPA has organized $210 \mathrm{MW}$ of its base load capacity under two performance management contracts (PMCs). These PMCs provide private management using public employees to operate and maintain the plants. The contracts contain performance-based incentives for reducing plant operating costs. The major fuel types include residual fuel oil (RFO \#6) and diesel \#2 distillate. Figure 5 shows GPA's generation by fuel type. Note that in FY 2010 99\% of GPA's electricity generation came from RFO. RFO includes both high and low sulfur sources. 


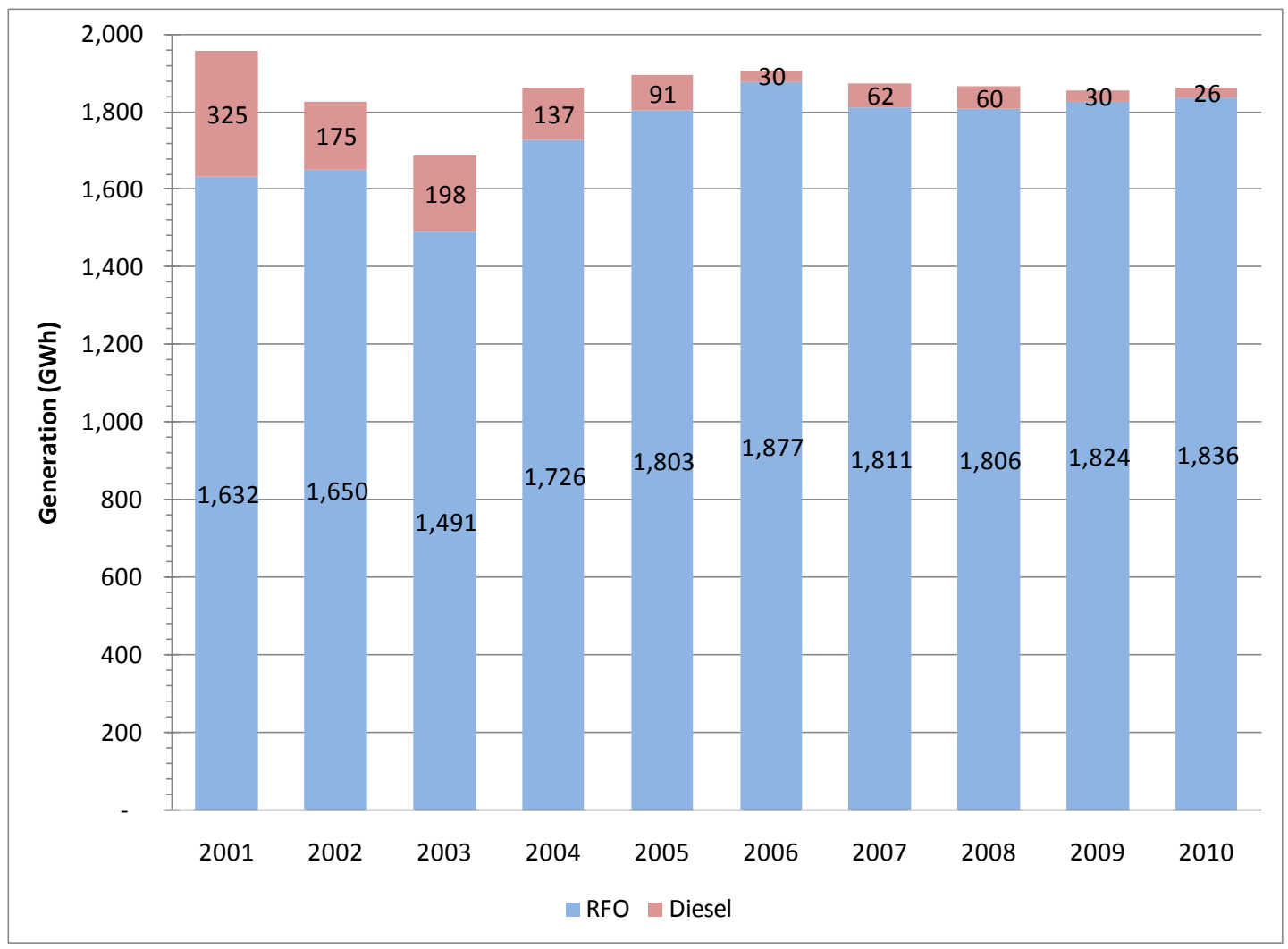

Figure 5. GPA gross generation by fuel type ${ }^{10}$ Source: GPA

According to GPA, "several systemic shocks, such as the Gulf war, SARs [Severe Acute Respiratory Sydrome], major typhoons, and rising fuel prices occurred during this period, adversely affecting the Guam economy. As a result, the demand for electric power contracted or remained flat relative to FY 1998," (Guam Power Authority, 2008).

The top plot in Figure 6 shows the gradual decline of generation, from a high of 1.956 billion $\mathrm{kWh}$ in 2001 to 1.862 billion $\mathrm{kWh}$ in 2010, a 5\% decline in nine years ${ }^{11}$. Electricity generation is measured at the generators in the power plants. The fuel use also declined during this same period, while the fuel efficiency improved between 2003 and 2004 and remained relatively flat during the last seven years.

In 2010 the overall system heat rate was 9,670 Btu/kWh. GPA provided historical fuel heating values from which the average value of 6.275 MMBtu/bbl for high sulfur fuel oil and low sulfur fuel oil ${ }^{12}$. Although the fuel heating value of diesel is value is $5.760 \mathrm{MMBtu} / \mathrm{bbl}$, because diesel is only a small proportion of the fuel mixture, it was not broken out separately. As a comparison to other island power systems, Hawaii's overall system heat rate was about $10,500 \mathrm{Btu} / \mathrm{kWh}^{13}$ and the U.S. Virgin Island's system-wide average was about $15,200 \mathrm{Btu} / \mathrm{kWh}^{14}$.

\footnotetext{
${ }^{10}$ GPA March 2011.

${ }^{11}$ GPA March 2011.

12 GPA March 2011.

${ }^{13}$ E-mail correspondence with Kenneth Kelly - NREL, March 2011.

${ }^{14}$ E-mail correspondence with Adam Warren - NREL, March 2011.
} 


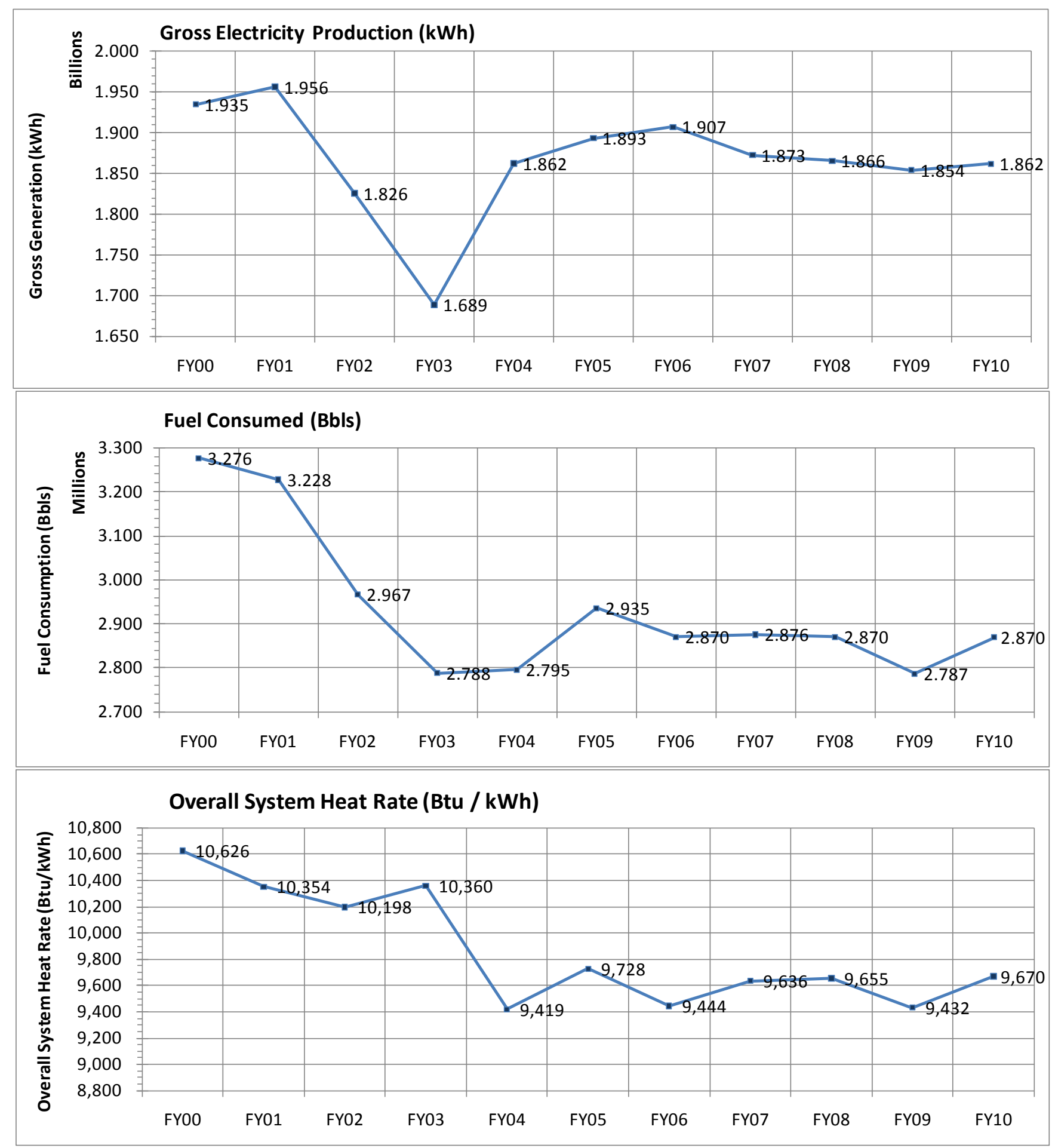

Figure 6. GPA gross electricity production, fuel consumption and overall system heat rate ${ }^{15}$ Source: GPA

\subsubsection{Consumption and Costs}

Figure 7 shows the overall annual energy consumption on Guam. The shape of the curve corresponds with the gross generation curve (top plot of Figure 6), showing a $6 \%$ decline in consumption between 2001 and 2010. The difference between generation and consumption is attributed to power-plant auxiliary losses, line losses, and losses from technical (billing errors, broken meters) and non-technical (theft) sources. Total losses in 2010 were about $12 \%$. There is a drop in 2003 due to 
several tragic events; Typhoons Chata'an, Pongsonga, and Halong all impacted Guam in 2002 causing extensive damage to infrastructure. Additioanlly, SARS and the attacks of September 11, 2001, led to reduction in tourism.

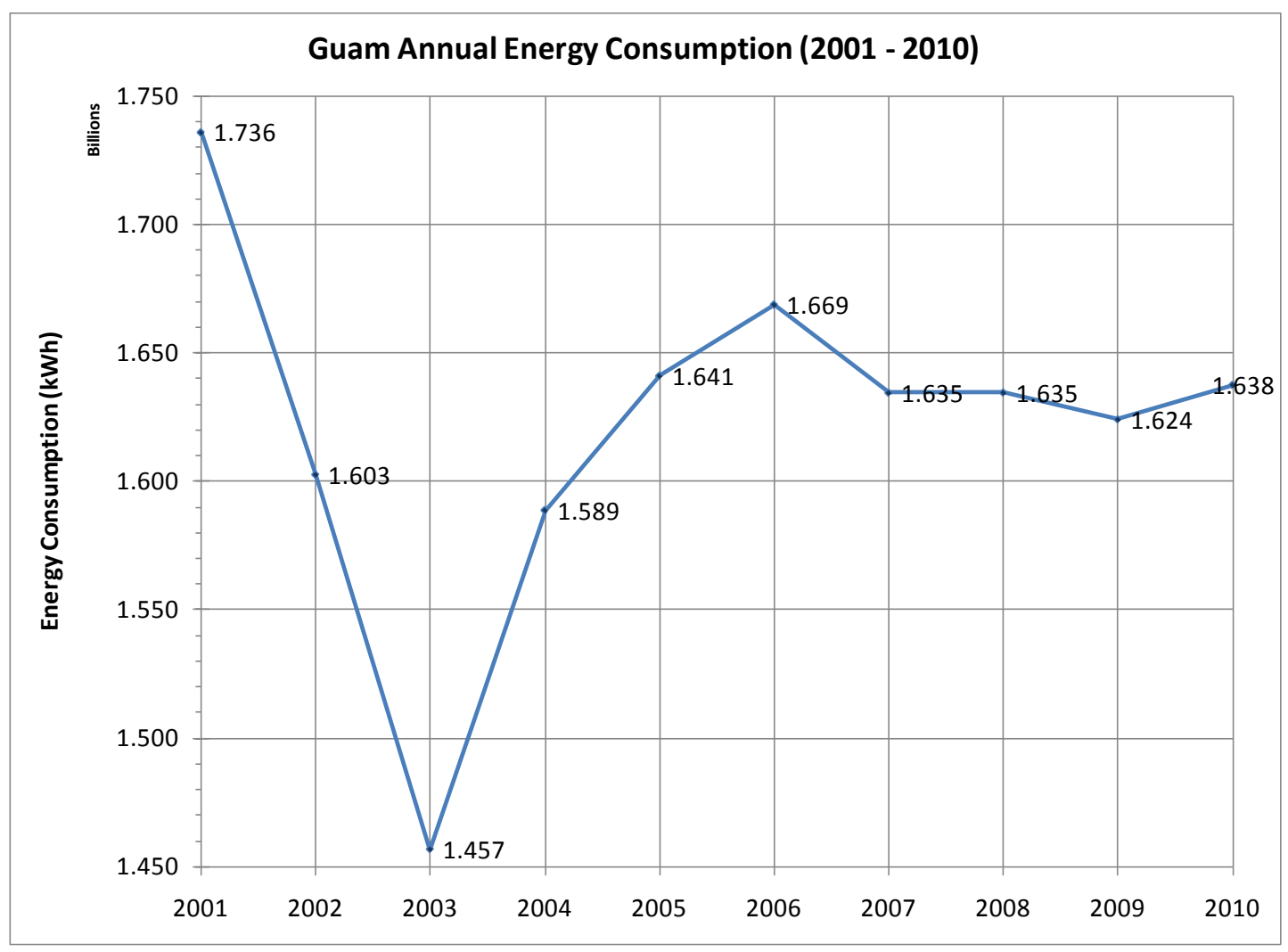

Figure 7. Historical annual island energy consumption $(2001-2010)^{16}$ Source: GPA

Figure 8 shows three daily load profiles for the overall GPA system. The hourly data are taken over the one-year time period between March 1, 2009 and February 28, 2010. The green plot is the hourly average over the entire year. The red plot shows hourly data for the day of the year in which the hourly maximum load occurs (October 13, 2010), and the blue plot shows hourly data for the day of the year where the hourly minimum load occurs (May 7, 2009). On an annual average basis, the minimum load (approximately 180 MW) occurs between 04:00 and 05:00, and the peak load (around $240 \mathrm{MW)} \mathrm{occurs}$ between 19:00 and 20:00, representing a 25\% change in load. On the day with the hourly maximum load, the minimum of $189 \mathrm{MW}$ occurs at 04:00, and the maximum of $272 \mathrm{MW}$ occurs at 19:00, representing a change in load of $34 \%$. On the day with the hourly minimum load, the minimum of 144 MW occurs at 01:00, and the maximum of 247 MW occurs at 20:00, representing a change in load of $42 \%$. 


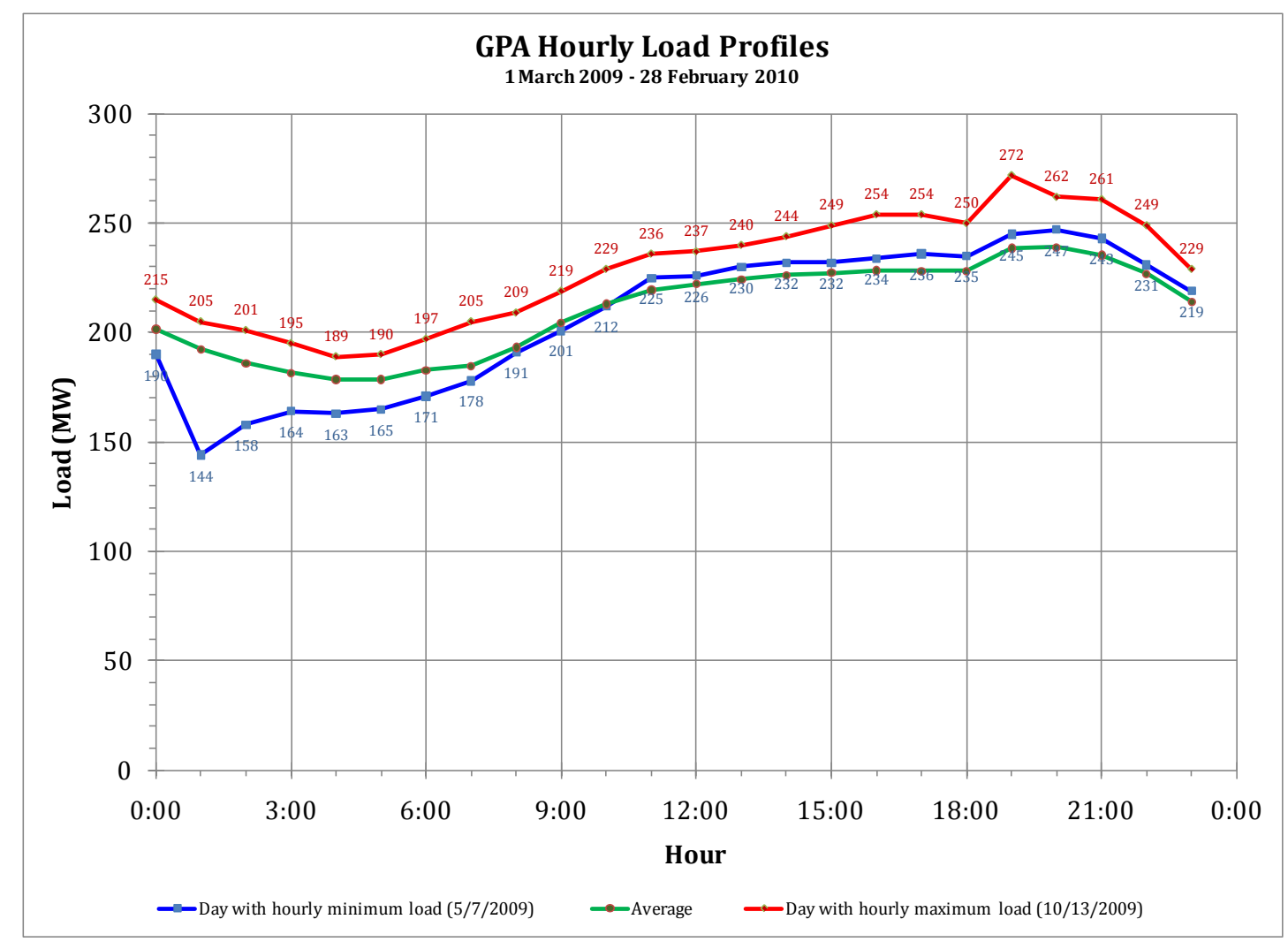

Figure 8. Overall GPA system hourly load profiles (March 1, 2009 - February 28, 2010) ${ }^{17}$ Source: GPA

Electricity is produced by imported oil (RFO \#6) and diesel (\#2 distillate). The total consumption of oil in 2007 was $14,230 \mathrm{bbl} / \mathrm{day}^{18}$. In 2009 , the average cost of electricity was $\$ 0.23$ per kWh and the GPA's 2010 Levelized Energy Adjustment Clause factor was $\$ 0.12465 / \mathrm{kWh}$ (Effective August 1, 2010) ${ }^{19}$.

In order to understand where energy efficiency measures should be focused, the electricity consumption has been broken down by end-consumer (see Figure 9). The energy statistics available for the island present energy consumption by commercial, residential, U.S. Navy, government, and street lighting sectors. Historical data is available for the period between 2001 and 2010, so a historical average was used to compare these sectors over the 10 -year timeframe ${ }^{20}$. The largest consumers of electricity on Guam are the commercial and residential sectors, followed by the U.S. Navy and government. As a group, private hotels dominate GPA's commercial load, and the airport is the largest civilian critical load. Figure 10 shows the Guam energy consumption by sector between 2001 and 2010.

\footnotetext{
${ }^{17}$ GPA March 2011.

${ }^{18}$ CIA World Factbook: https://www.cia.gov/library/publications/the-world-factbook/geos/gq.html.

${ }^{19}$ By comparison, the U.S. Virgin Islands Water and Power Authority set a LEAC factor of \$0.22/kWh in 2010 .

${ }^{20}$ Secretariat of the Pacific Community: http://www.spc.int/prism/country/gu/stats/Utilities/Utilities.htm\#PH5.
} 




Figure 9. Guam energy consumption by sector (2001 - 2010 average $)^{21}$ Source: GPA

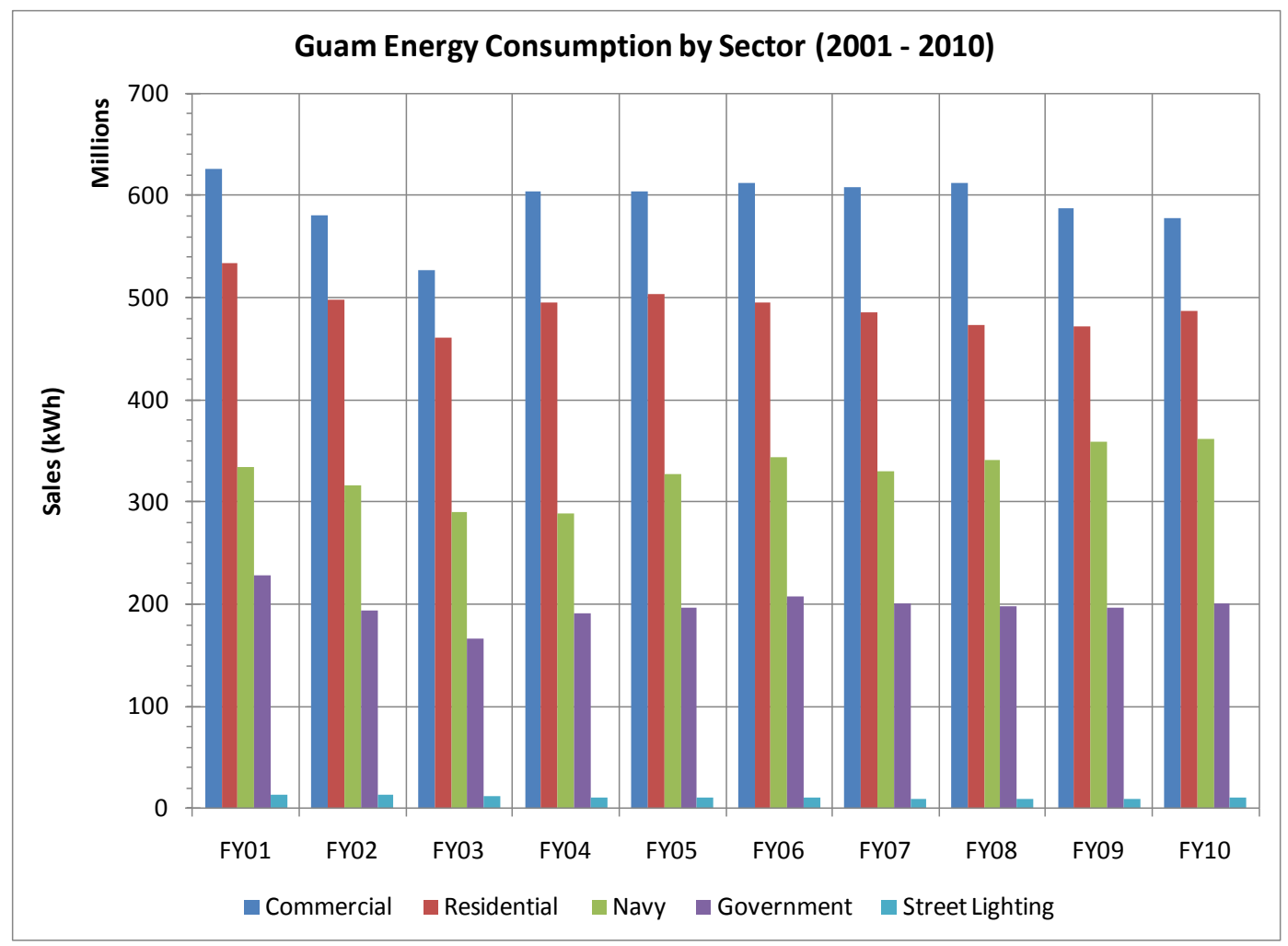

Figure 10. Guam energy consumption by sector $(2001-2010)^{22}$ Source: GPA

${ }^{21}$ GPA March 2011.

22 Ibid. 
GPA is working with DOD during planning to ensure there is adequate capacity to serve the load of military projects targeted for the island. The current best estimate of the additional base load from the buildup is $30 \mathrm{MW}$ with an additional $25 \mathrm{MW}$ of transient/peaking load. GPA believes there is sufficient generation capacity currently in the system to meet the planned load requirements. DOD has also expressed that a preferred solution to complement GPA's existing generation system is to recondition up to five peaking/emergency combustion turbine units. GPA is working with DOD to identify transmission and distribution projects that would be required to meet the military service requirements. DOD has been committed to the principle of ensuring the civilian community is not negatively impacted by the cost of the buildup.

\subsubsection{End Use}

Understanding the building stock is important to know how energy is being consumed within a building, as energy use will vary by construction type/materials and the age of the building. Other parameters that impact energy use are climate and culture. The goal in reducing energy consumption is to understand how it is being utilized and to know where conservation and efficiency measures can be applied. By identifying the end-uses of energy consumption, analysis can be undertaken to identify areas where improvements can be made.

NREL's site visit demonstrated that in typhoon prone areas, such as Guam, buildings are typically constructed of concrete to withstand the wind and water. Buildings that are lightweight and constructed of wood frames or are older and have deteriorating structures are vulnerable to typhoon destruction.

Reinforced concrete is often used as the building material in typhoon 'alleys'; this type of construction was observed in Guam. The building portfolio is comprised of hotels, the airport, government and military buildings, schools, hospitals, medical clinics, commercial property, and residential buildings, such as apartments and single family dwellings. The number of buildings classified within each category is unknown; however opportunities were identified within the energy end-use sectors as provided by the Government of Guam and GPA. The direction the Government is trying to head is exemplified by the Leadership in Energy and Envionremental Design (LEED)-registered buildings under construction on the Guam Community College Campus, shown in Figure 11.

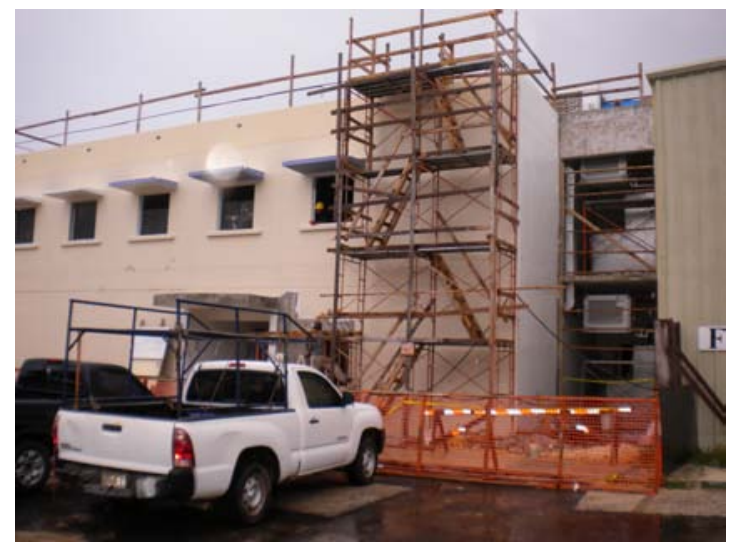

Figure 11. Guam Community College's LEED-registered building under construction Source: NREL/PIX 18588

Data collected from the site visit have indicated that the highest end users of energy on Guam are commercial, residential, government, Navy, and then street lighting, as shown in the pie chart above in Figure 9. End use within the commercial, residential, and government sectors are discussed in more 
detail in the following sections. Delving into the end use in more detail allows for solutions to be identified either in terms of energy conservation or energy efficiency.

Energy conservation and energy efficiency can be combined to create an effective strategy to achieving overall island energy reduction. Energy conservation is any behavior that results in the use of less energy. Turning the lights off when you leave the room is one example of conserving energy. Energy efficiency, on the other hand, is the use of technology that requires less energy to perform the same function. A compact fluorescent light bulb that uses less energy than an incandescent bulb to produce the same amount of light is an example of energy efficiency ${ }^{23}$.

\subsubsection{End Use for Commercial Sector}

Commercial building consumption is led by offices, retail, luxury hotels, and the education sector. End users within commercial buildings are reported by GPA as being interior lighting, cooling, miscellaneous equipment, refrigeration, ventilation, exterior lighting, water heating, and cooking. The end use is broken out for commercial buildings in Figure $12^{24} .1993$ is the most current end use data available.

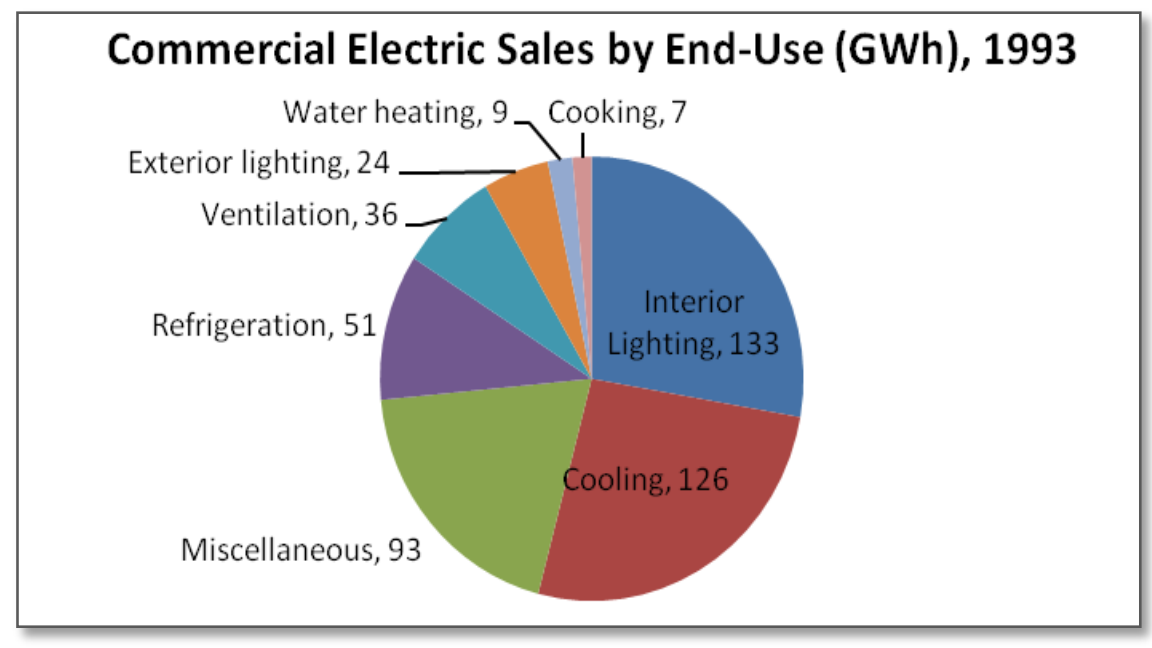

Figure 12. Commercial electric sales by end-use, 1993 Source: GPA

Many assumptions were made by the authors commissioned to calaculate the sector break-down for GPA; therefore some scrutiny may be necessary when analyzing these results. A more detailed study may be required in commercial buildings to determine whether interior lighting is truly higher than cooling.

Additionally, more information on the end-users within the 'miscellaneous' category would be helpful. By understanding more about the equipment and plug loads that are consuming energy, a commercial organization will have better control over managing and reducing their energy consumption. An example is a company that leaves computers, printers, and fax machines on or on standby overnight. Without knowing what the components of the 'miscellaneous' category are it is difficult for the organization to know how to make reductions.

\subsubsection{End Use for Residential Sector}

GPA reports that consumption by the residential sector is impacted by the rate of electricity, which fluctuates primarily based on the cost of fuel. Despite a growth in population and in electricity

\footnotetext{
${ }^{23}$ Energy Information Administration, http://www.eia.doe.gov/energyexplained/index.cfm?page=about_energy_efficiency.

${ }^{24}$ Guam Power Authority, Demand Side Management Plan, April 1993, Section II.
} 
customers, Figure 13 shows that the average kWh sales per residential customer declined by $16 \%$ between 2001 and $2010^{25}$. This decrease is thought primarily to reflect reduced consumption due to higher rates (shown in Figure 14). From 2001 through 2010, the average annual fuel bill for GPA's residential customers has increased by $44 \%$. The graphs show the actual activity in the thicker, blue line; the average trend lines are shown in the thin, black line.

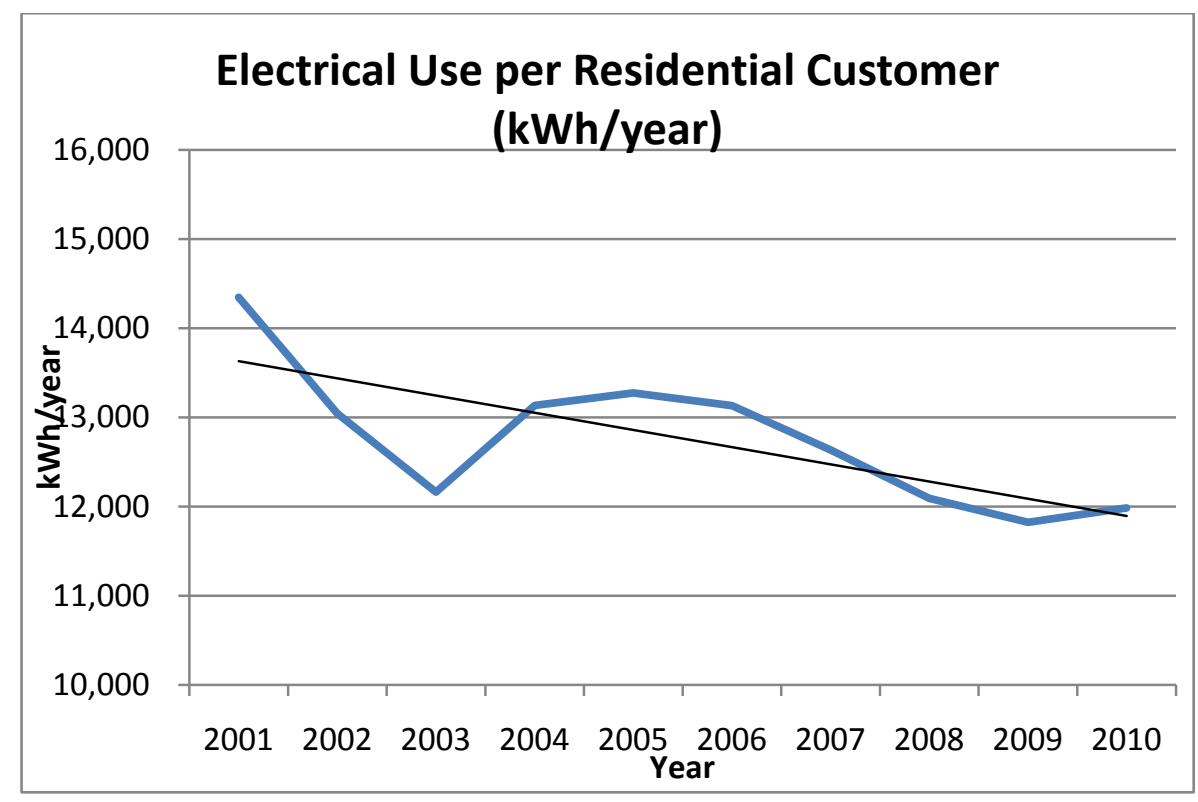

Figure 13. Annual energy sales (residential sector) Source: GPA

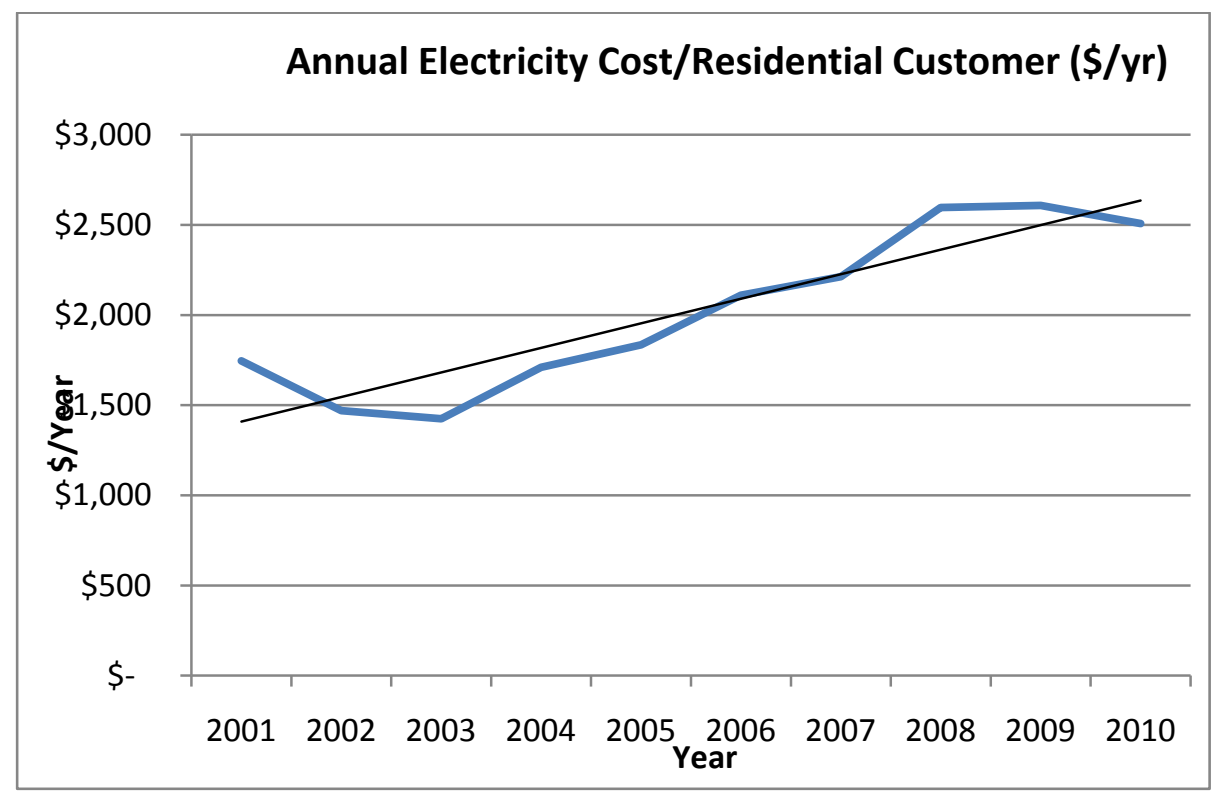

Figure 14. Average annual costs per residential customer Source: GPA

\footnotetext{
${ }^{25}$ End use data provided by GPA.
} 
In 1993, the highest energy consumption in Guam within the residential sector was water heating, followed by air conditioning and household appliances, as shown by the end use of energy in residential buildings shown in Figure $15^{26}$. This tells us the best opportunities for the residential sector include reducing electrical use for water heating, improving air conditioning, improving appliances, and changing to more efficient lighting.



Figure 15. Residential electric sales by end user Soure: NREL

\subsubsection{End Use for Government Sector}

A snapshot glimpse for the Guam Government sector indicates that the largest consumption of fuel for November 2010 was related to a few specific agencies. The Guam Waterworks Authority (GWA) had the largest energy consumption, followed by the Department of Education, the University of Guam, and the hospital. This breakdown is shown in Figure 16.

${ }^{26}$ GPA, Demand Side Management Plan, April 1993, Section II. This is the latest year that has data available. 


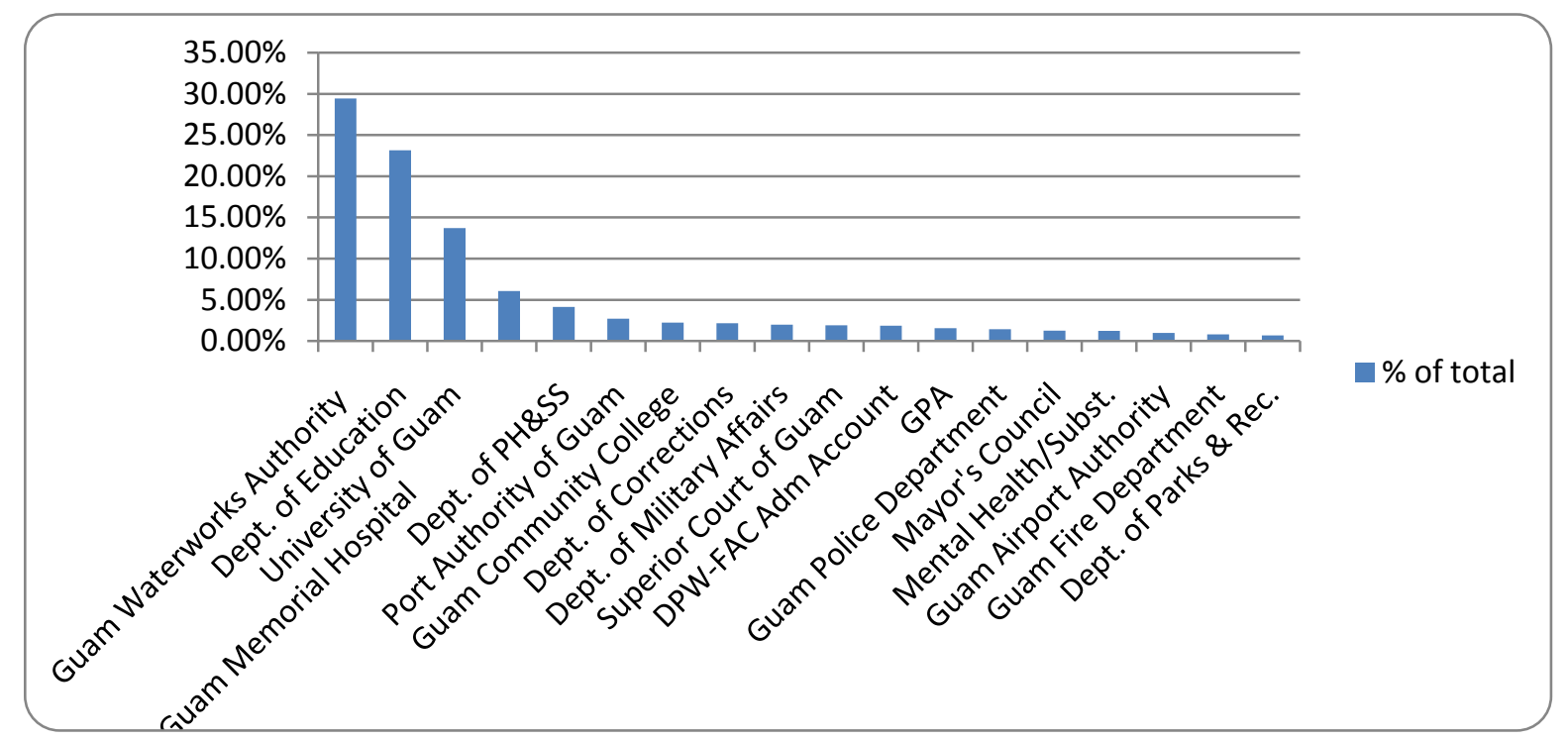

Figure 16. Guam government sector energy consumption by percentage of total energy consumption ${ }^{27}$ Source: NREL

While this type of assessment is not comprehensive in its review of energy consumption, it provides a glimpse of where energy is being consumed within the sector. Ideally, an assessment would cover multiple years worth of data and be compared to the total floor area of each agency. The energy consumption per floor area provides a more comprehensive form of benchmarking energy consumption activities within buildings and highlights where energy is being consumed more thoroughly.

Without further investigation it is difficult to confirm assumptions; however assumptions can be made about the end use within each agency. For example, the energy consumption at GWA may be a result of typical energy end use, such as lighting, air conditioning, and equipment; however motors, drives, and pumps may contribute significantly to the consumption. GWA is responsible for treating and pumping water, therefore it can be assumed that the primary energy consumers are due to these main activities. The Department of Education, the University of Guam, and Guam Community College are most likely responsible for a large building portfolio with high cooling, lighting, and plug loads, whereas the hospital presumably has the same loads, but on a 24-hour demand scale.

\subsubsection{Current Status of Energy Policy}

Across the global landscape, many communities are turning to policy as a way to institute clean energy technologies. Many states, territories, local governments, and communities are interested in adopting strategies that promote energy efficiency and renewable energy. Policy is a mechanism many governments use to advance and support energy efficiency and renewable energy objectives. Policy implementation can aid in market adoption and assist in laying a foundation for a green economy while providing investors with reassurance within market transformation. Policy can be an effective tool Guam can use to implement their energy efficiency and renewable energy goals, increase energy diversity, and decrease dependence on imported fossil fuels. Additionally, there are environmental benefits such as emissions reduction, reduction of water consumption, thermal pollution and adverse land-use impacts. Oftentimes, these environmental effects can be beneficial in a cost-benefit analysis when factoring in future fossil fuel generation.

The following subsections discuss energy policies currently in place in Guam.

\footnotetext{
${ }^{27}$ Data provided by the Guam Energy Office for November 2010.
} 


\subsubsection{Net Metering}

Net metering for distributed generation was enacted in December 2004 under Guam Public Law (PL) $27-132 .{ }^{28}$ The net metering policy is an agreement between GPA and its customers for a variety of renewable technologies; fuel cells, microturbines, wind energy, biomass, hydroelectric, solar, or hybrid solar systems. In order to participate in this program the system cannot exceed the eligible size of 25 $\mathrm{kW}$. GPA will pay for any additional meters needed as well provide customer-generators with a bidirectional energy meter. Customers must meet all prescribed safety guidelines and electric codes. GPA does not require additional measures, controls, or supplemental insurance once these requirements have been met. Customers who take advantage of net metering can request billing on either a monthly, semiannual, or annual basis. Systems that produce excess generation will be compensated; however, the rules for this policy have yet to be set by the Guam Public Utilities Commission (PUC), which was required within 120 days of the authorizing legislation.

Through interviews it has been learned that the PUC has currently enacted these rules. If the energy the customer produces is zero or negative during a particular billing cycle, the customer shall pay only the non-energy charge portion; if the customer's net energy is negative they will be credited the kilowatt hour different in the next billing cycle. ${ }^{29}$ Table 6 lists the current net metering customers.

Table 6. Current GPA Net Metering Customers

\begin{tabular}{|l|l|l|l|l|}
\hline \multicolumn{1}{|c|}{ Location } & Technology & Size (KW) & Cust Type & $\begin{array}{l}\text { Activation } \\
\text { Date }\end{array}$ \\
\hline Golondrina Avenue, Barrigada Heights & PV & $8.4 \mathrm{KW}$ & Residential & $2 / 17 / 2009$ \\
\hline Flores Rosa Loop,Barrigada Heights & PV & $8.4 \mathrm{KW}$ & Residential & $5 / 19 / 2009$ \\
\hline Daisy Lane,Latte Heights & PV & $7.7 \mathrm{KW}$ & Residential & $4 / 17 / 2009$ \\
\hline Tun Emeterian Camacho St.,Oka,Tam. & PV & $8.4 \mathrm{KW}$ & Residential & $9 / 25 / 2009$ \\
\hline Acho Latte St.,Macheche,Dededo(2 ea.) & PV & $\begin{array}{l}7.7 \mathrm{KW}(2 \\
\text { ea.) }\end{array}$ & Commercial & $1 / 22 / 2010$ \\
\hline Toto Canada Rd.,Barrigada & PV & $2.96 \mathrm{KW}$ & Residential & $12 / 1 / 2009$ \\
\hline Toto Canada Rd.,Barrigada & Wind & $1.8 \mathrm{KW}$ & Residential & $6 / 22 / 2009$ \\
\hline Chalan Villagomez,Latte Heights & Wind & $1.8 \mathrm{KW}$ & Commercial & $6 / 1 / 2009$ \\
\hline $\begin{array}{l}\text { Mangilao, GCC Compound, New Learning } \\
\text { Center }\end{array}$ & PV & $24.8 \mathrm{KW}$ & Commercial & $12 / 10 / 2010$ \\
\hline $\begin{array}{l}\text { Mangilao, GCC Compound, Allied Health } \\
\text { Center }\end{array}$ & PV & $29.4 \mathrm{KW}$ & Commercial & $\begin{array}{l}\text { Under } \\
\text { Construction }\end{array}$ \\
\hline
\end{tabular}

\subsubsection{Energy-Efficient Appliance Rebate Program}

The "State Rebate Program" sponsored by DOE through the American Recovery and Reinvestment Act of 2009 rolled out in Guam $2010^{30}$. Unfortunately, funds are limited and this program has not been locally invested and therefore will have a short lifespan. However, incentives to replace inefficient equipment with new ENERGY STAR certified products, including washing machines, refrigerators, and air conditioners (both room and split type models), will no doubt show measureable savings.

Approximately $\$ 160,000$ was set aside for this program.

\subsubsection{Solar-Ready Residential Building Requirement}

Effective in October 2000, the Guam Energy Code adopted installation requirements for new residential low-rise buildings. The building code now requires that all new residential construction must include the appropriate solar thermal equipment that would allow future solar thermal unit installation ${ }^{31}$.

\footnotetext{
${ }^{28} \mathrm{http}: / / w w w . g u a m l e g i s l a t u r e . c o m / P u b l i c \_L a w s \_27 t h / P . L . \% 2027-132 . p d f$.

${ }^{29}$ Net Metering Program Interconnection Policy, 2/26/2009.

${ }^{30} \mathrm{http}: / / \mathrm{www}$.guamenergy.com/announcement-to-appliance-retailers/.

${ }^{31} \mathrm{http}: / /$ www.dsireusa.org/documents/Incentives/GU01R.htm.
} 


\subsubsection{Building Codes}

The current building codes in Guam are outdated. The Guam Energy Code uses ASHRAE 90.1-1989 for commercial buildings and follows the 1992 Model Energy Code for residential buildings ${ }^{32}$. These codes were adopted more than 12 years ago with provisions to allow the Department of Public Works to administer the latest edition of the code for design and construction.

The most current green building codes to be recommended are:

- Commercial: ASHRAE 90.1 2010, Energy Standard for Buildings Except Low-Rise Residential Buildings/International Energy Conservation Code (IECC), 2009

- Residential: International Energy Conservation Code, 2009.

These codes are set up to address heat loads, but tropical areas can choose what is applicable as the IECC tends to group energy requirements and discount tropical climate impacts on buildings.

As of October 28, 2010, Guam adopted the 2009 IECC. Part of the requirements of that adoption are to establish a Guam Building Code Council whose responsibilities will include providing "recommendations for further amending or adding to the codes adopted with this legislation, including the possible amending or adoption of Appendices A, B, and D of the International Building Code, 2009 edition, the International Property Maintenance Code, 2009 edition, the International Energy Conservation Code, 2009 edition, the Model Tropical Energy Code, and any other construction codes as the Council may deem appropriate,"33. Adoption of the Tropical Building Code is only the first step to addressing energy use in new construction and major renovations; but current building stock is a concern. Compliance and enforcement are other issues that must be addressed.

\subsubsection{Renewable Portfolio Standard}

Guam has not adopted the traditional Renewable Portfolio Standard (RPS) but has an RPS goal that was introduced as Guam Bill 166 and enacted in March 2008 through the Guam legislature - Guam Public Law 29-62 $2^{34}$. This law was an attempt to address three important initiatives: (1) promote the development of renewable energy, (2) establish an RPS, and (3) study the feasibility of a rate structure through the PUC that would support renewable energy implementation. It established a renewable energy goal of $25 \%$ renewable energy by 2035 . This goal is not compulsory like a traditional RPS, which is legally binding.

If Guam is to move toward decreased fossil fuel use and increased energy diversity, an RPS can be a very effective tool. The following is Guam's timeline for renewable energy integration as spelled out in their 2008 RPS goal.

- $5 \%$ of net electricity sales by December 31,2015

- $8 \%$ of net electricity sales by December 31,2020

- $10 \%$ of net electricity sales by December 31,2025

- $15 \%$ of net electricity sales by December 31,2030

- $25 \%$ of net electricity sales by December 31, 2035.

Here are a couple island examples:

\footnotetext{
${ }^{32} \mathrm{http}$ //bcap-ocean.org/state-country/guam.

${ }^{33}$ Government of Guam Bill No. 460-30 (COR), passed October 28, 2010.

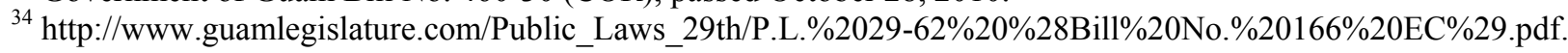


U.S. Virgin Islands has passed legislation and established that "peak demanded generating capacity" come from a renewable source of $30 \%$ by $2025 .^{35}$

Hawaii has established a $70 \%$ fossil fuel reduction target by the year $2030,40 \%$ of its net electricity sales.

These goals are all inclusive of energy usage as a whole and include the transportation sector. ${ }^{36}$

\subsubsection{Solid Waste}

Solid waste generation and disposal represent significant costs and challenges for island communities like Guam. Solid waste represents a potential source of material that can be converted to energy. The first step in determining the potential is to understand present waste management practices, waste generation quantities, waste composition, disposal costs, and regulatory environment.

Solid waste management issues in Guam are complicated. Under a Consent Decree issued in 2004, the United States District Court ordered the Government of Guam to plan for the closure of Ordot Dump and to construct a new sanitary landfill that would be fully compliant with subtitle D of the Resource Conservation and Recovery $\mathrm{Act}^{37}$.

Over the next four years, the Government of Guam made little progress in implementing the Consent Decree. In March 2008, the District Court of Guam issued a Court Order ${ }^{38}$ to appoint consulting firm Gershman, Brickner and Brayton (GBB) as the Federal Receiver to enforce compliance with the Consent Decree. Under the terms of this order, GBB took control of the Guam Solid Waste Management Division and assumed all of its responsibilities. GBB is presently managing the closure of Ordot and the construction of the new Layon Landfill.

The Layon landfill is scheduled to be completed and opened in the summer of 2011. In January of 2011, Senator Tom Ada introduced a bill to create an autonomous agency - the Guam Solid Waste Management Authority - to take over solid waste management responsibilities from GBB when the terms of the Consent Decree are fulfilled.

The total cost of constructing Layon Landfill and related consent decree projects was estimated to be $\$ 98$ million in the August 2010 Quarterly Receiver Report. ${ }^{39}$ GBB developed the financing plan for the process and assisted the Government of Guam with raising the funds. GBB is continuing to identify cost-saving measures for construction of the landfill.

To cover debt repayment and ongoing operations and maintenance costs, the new Solid Waste Management Authority will need to charge a tipping fee and maintain a minimum flow of municipal solid waste (MSW) into the landfill. In July 2009, the U.S. Navy, GBB, and the Government of Guam signed a letter of intent stating that it is the intent of the U.S. Navy to negotiate a contractual arrangement for solid waste management services with the new entity that will run the landfill. Essentially, U.S. Navy waste is needed to help meet project cash flow and revenue requirements for landfill operations and bond repayment. If U.S. Navy waste is included, it will also lower rates for the

\footnotetext{
${ }^{35} \mathrm{http}: / /$ www.dsireusa.org/incentives/incentive.cfm? Incentive_Code=VI06R\&re=1\&ee=1.

36 Ibid.

${ }^{37}$ Consent Decree for the Closure of Ordot Dump, Feb 2004, available online at http://iconguam.com/guamsolidwaste/docs/Federal\%20Consent\%20Decree\%20[2-12-04\%20in\%20Civil\%20Case\%200222].pdf accessed January 31, 2011.

${ }^{38}$ The Court Order can be found at http://www.guamsolidwastereceiver.org/pdf/court_order.pdf accessed January $31,2011$.

${ }^{39}$ Quarterly Report of the Receiver, August 11, 2010. pg 29. Accessed online on March 3, 2011: http://www.guamsolidwastereceiver.org/pdf/Tab_1_Quarterly_Report_of_the_Receiver_8_11_10.pdf.
} 
rest of the island. Final tipping fees have not yet been approved by the PUC ${ }^{40}$. However, proposed rates have been submitted to the PUC and are shown in

Table 7. Proposed and Interim Tip Fees

\begin{tabular}{|c|c|c|c|c|}
\hline \multicolumn{5}{|c|}{ Landfill Tip Fees: } \\
\hline & \multicolumn{2}{|c|}{$\begin{array}{l}\text { With } \\
\text { Military }\end{array}$} & \multicolumn{2}{|c|}{\begin{tabular}{|l|} 
Without \\
Military
\end{tabular}} \\
\hline Commercial (\$/ton) & $\$$ & 156 & $\$$ & 174 \\
\hline Residential (\$/month) & $\$$ & 28 & $\$$ & 32 \\
\hline \multicolumn{5}{|c|}{ Transfer Station Rates: } \\
\hline Effective Date & & & & Jrop (> \\
\hline Current & $\$$ & 2.50 & $\$$ & 5.00 \\
\hline September 1, 2010 & $\$$ & 4.00 & $\$$ & 8.00 \\
\hline March 1, 2011 & $\$$ & 5.50 & $\$$ & 11.00 \\
\hline September 1, 2011 & $\$$ & 7.50 & $\$$ & 15.00 \\
\hline
\end{tabular}

The impacts of increased tipping fees on waste collection rates are not known at this time. However, it is likely that higher tip fees will lead to increased illegal dumping and reduce the amount of waste going to landfills. Depending upon the cost of recycling, it may also lead to increased participation in recycling programs.

\subsubsection{Guam Waste Generation and Composition Analysis}

Minimal data on the amount and format of Guam's solid waste stream is available. In the August 2010 Quarterly Report, the Receiver reported that from June 1, 2009, through June 1, 2010, 80,500 tons of solid waste was delivered to Ordot. This is quite a bit lower than a previous estimate. In a report entitled Estimation of Potential Landfill Gas Yields for the Ordot Dump ${ }^{41}$, Duenas Associates and URS Corporation estimated that between 2004 and 2007 approximately 120,000 tons per year were being (or would be) disposed of in the Ordot Dump. As the Duenas/URS figure was based on estimates and the 2010 figure is based on scaled data, NREL will assume an annual waste estimate of 80,500 tons/year. This figure does not include green waste and corrugated cardboard, which were banned from Ordot several years ago. These materials are now being recycled by the private sector on Guam.

This annual total also does not include DOD solid waste. The amount of waste generated by DOD is estimated in the Final Environmental Impact Statement for the build-up ${ }^{42}$. The quantity of waste produced by DOD is highly dependent upon the population of military and non-military personnel associated with the build-up and related activities. DOD is also implementing an aggressive recycling program, with a target diversion rate of $50 \%$ by 2015 and every year thereafter. It is presumed that some of the material diverted to recycling would also be potentially suited for conversion in a waste-to-energy (WTE) plant.

\footnotetext{
${ }^{40}$ Quarterly Report of the Receiver, December 9 2010,pg 34. Accessed online on March 3, 2011: http://www.guamsolidwastereceiver.org/pdf/Tab_1_Quarterly_Report_of_the_Receiver_12_9_10_Final.pd.

${ }^{41}$ Estimation of Potential Yields of Landfill Gas from the Ordot Dump. Duenas \& Associates and URS Corp. July 2005. Accessed online at: http://guamsolidwastereceiver.org/pdf/RFP\%20SWD001-11\%20-\%201b\%20\%20Est.\%20of\%20Poten.\%20LFG\%20Yields\%20Ordot\%20Dump.pdf.. Accessed January 29, 2011.

${ }^{42}$ Solid Waste data provided by Captain Peter Lynch to Scott Haase via email March 20, 2011. Table is entitled Table 2.4-1 Projected Solid Waste Estimates, pg 2-109 and 2-110. All data in the table are based on per capita waste generation estimates of 7.4 pounds per person per day.
} 
The table shows a total solid waste volume from DOD and non-DOD personnel and construction activity starting at 30,467 tons/year in 2010 (including 10\% recycling of DOD waste) and reaching a peak of 66,900 tons/year in 2015 (including 50\% recycling), and then declining to 37,425 tons/year in 2019. For purposes of this report, NREL will assume the lowest value, or 30,467 tons/year of waste produced by DOD. This value is potentially conservative and there may be significantly more material available from DOD for a WTE plant.

Thus the total potential waste stream available is 110,967 tons/year. This is the number that we will use later to estimate the potential energy that could be produced from Guam's waste.

To our knowledge there are no recent, statistically-valid waste composition analysis studies that have been conducted on Guam's waste stream. In its December 2010 Quarterly Report, the Receiver provides information on a new waste characterization study being performed by the Solid Waste Management District (SWMD) ${ }^{43}$. This is a limited study in that it is only focusing on the waste generated by participants in SWMD's pilot recycling program. As part of the pilot recycling program, some residents have agreed to have their waste collected separately and sorted into categories and weighed over the next year. The first sort was conducted on October 12, 2010. A total quantity of 457 pounds of waste from eight residents was sorted into categories. The breakdown of materials into categories is shown in Figure 17. Glass and metals (non-combustible) represent $13 \%$ of the stream.
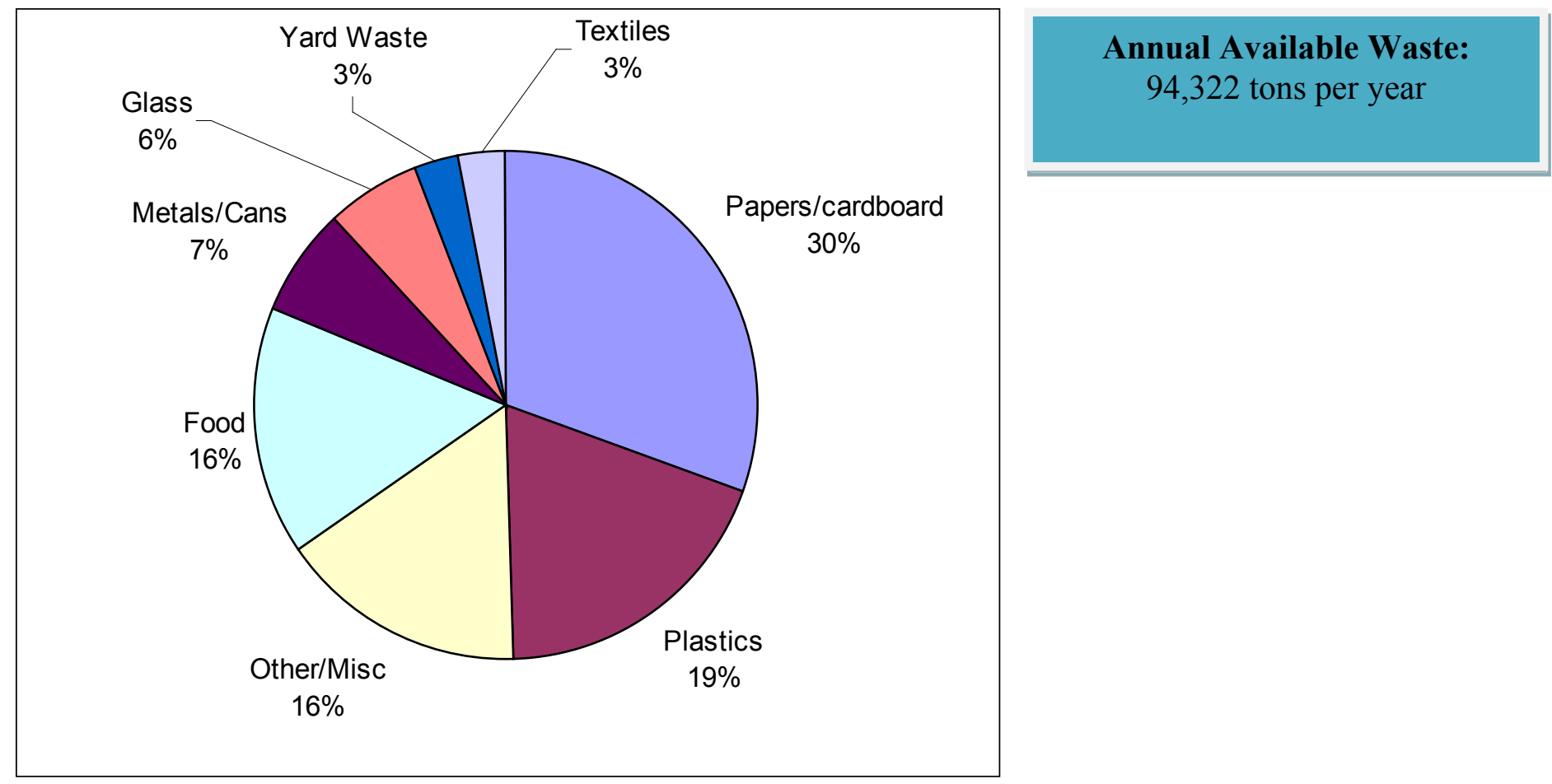

Figure 17. October 2010 waste characterization study (limited sample) Source: NREL

In addition, NREL located a reference to a 1995 study quoted in a memo from the Receiver; the Receiver provided NREL with a copy of this report ${ }^{44}$. The 1995 report estimates that Guam produces over 600 tons of solid waste per day. However, this number is not based on scaled data and it is

\footnotetext{
${ }^{43}$ Quarterly Report of the Receiver, December 9 2010. Available on line at: http://www.guamsolidwastereceiver.org/pdf/Tab_1_Quarterly_Report_of_the_Receiver_12_9_10_Final.pd Accessed on March 3, 2011.

${ }^{44}$ Guam Solid Waste Weight Composition and Recycling Feasibility Study Final Report. Guam Environmental Protection Agency, May 19, 1995.
} 
considerably higher than the actual scaled data reported by GBB for the 2009-2010 timeframe. The 1995 study did conduct a detailed waste sort and characterization. The study found that approximately $13 \%$ of the material was either metal, glass, aluminum, or hazardous material.

\section{NREL also located a 1982 study that categorized Guam's waste in 1980 . The breakdown of the 1980 data is shown in}

Figure 18. Comparing the limited sample from 2010 with the analyses conducted in 1980 and 1995 , glass and metals (which are non-combustible and should be removed from any calculations estimating available WTE conversion) were estimated at 13\% of the total in 2010 and 1995, and 15\% of the total in 1980 .

As the 2010 sample is only from eight households, and pending the location of any more recent data, we will use the $15 \%$ value from the 1980 study as being the most representative and most conservative.

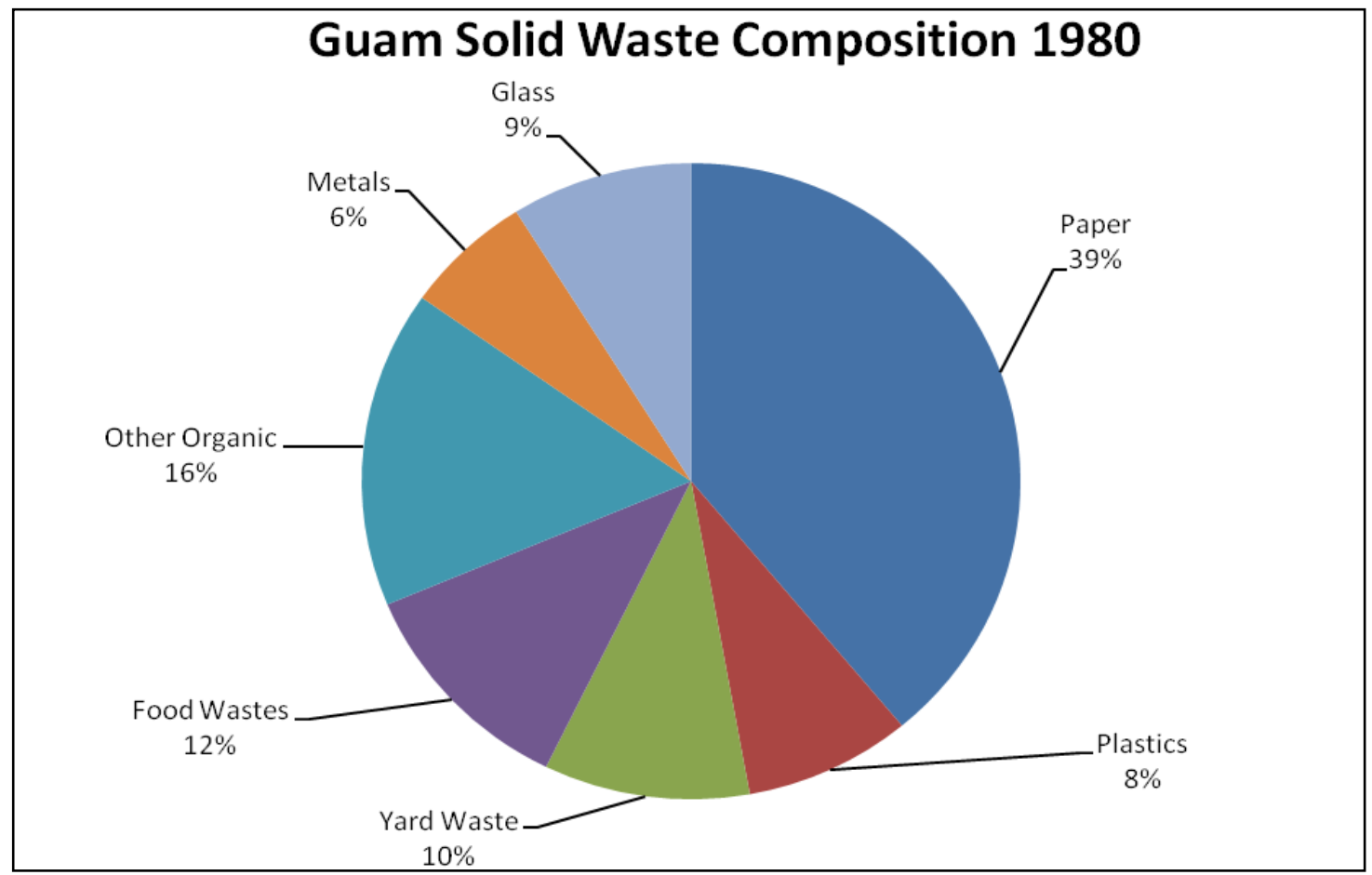

Figure 18. Guam's solid waste composition, $1980^{45}$

Source: Rossi Nayve Consulting Service and Associates

Assuming that the composition is still the same, and that the percentages also apply to the DOD stream, about $15 \%$ of the stream is non-combustible metals and glass and should be subtracted from the 110,967 tons per year of available waste. This leaves a potential available feedstock of 94,322 tons per year. We will use this value to estimate WTE potential in Section 3 of this report.

\subsubsection{Construction Waste}

There will be considerable construction and demolition (C\&D) waste associated with the military buildup on Guam. Section 18.2.5.1 of the EIS document states that the preferred alternative will be to dispose of this material in the U.S. Navy-owned landfill at Apra Harbor ${ }^{46}$. While there will be a temporary

\footnotetext{
${ }^{45}$ Rossi Nayve Consulting Services and Associates, A Study of Guam's Recyclable Wastes, Guam Solid Waste Management Plan, 1982. Referenced online: http://www.co.hawaii.hi.us/env_mng/iswmp_orig/Chapter\%2003.pdf, pg 5. Accessed February 12011.

${ }^{46}$ Guam and CNMI Military Relocation, Final EIS. Accessed online on March 3, 2011: http://www.guambuildupeis.us/documents/final/volume_6/Vol_06_Ch18_Hazardous_Materials_and_Waste.pdf.
} 
increase in $\mathrm{C} \& \mathrm{D}$ waste associated with the build-up, the quantity will vary and it is not a reliable feedstock that will be available over the 20-year life of any WTE plant, so it will not be added to the estimate of available waste for conversion to energy.

\subsubsection{Recycling}

Recycling provides a landfill diversion opportunity, as well as an economic opportunity within the commercial sector. Observations on-island and interviews with stakeholders indicated there is presently minimal recycling in Guam. Should a more comprehensive recycling program be implemented, the amount of material available for WTE could potentially be reduced depending on the materials that are recycled. Solid waste managers and planners need to carefully consider all of the costs and benefits of both WTE and recycling within a unified framework. The lifecycle economics of recycling on Guam need to be carefully evaluated. On-island markets are likely to be limited and the costs of shipping overseas need to be considered.

\subsubsection{Regulatory Framework}

During the site visit, the legalities surrounding PL 25-175 and the ramifications were noted. PL 25-175, "An Act to Approve and Amend the Integrated Solid Waste Management Plan," prohibits construction or operation of solid waste incinerators or WTE facilities on Guam. Specifically, PL 25-175 states:

Section 73113 is hereby added to Chapter 73, Division 3 of Title 10 of the Guam Code Annotated to read as follows:

Section 73113. Municipal Solid Waste Incinerators Prohibited. Notwithstanding any other provision of law, it shall be unlawful for any person to construct or operate on Guam a municipal solid waste incinerator or a waste-to-energy facility, as defined by the rules and regulations of the United States Environmental Protection Agency or the laws of the United States of America ${ }^{47}$.

NREL understands that the main reason this legislation was passed was to prohibit implementation of a controversial 1996 agreement between the Government of Guam and a company called Guam Resource Recovery Partners (GRRP). The agreement was entered into by the Executive Branch of the Government of Guam. It is NREL's understanding that the legislature had concerns that the agreement required the Government of Guam to provide GRRP with minimum quantities of waste that were beyond the amount of waste generated on the island. The legislature therefore passed a law prohibiting WTE.

It is clear that without legislative action or creative thinking, it is extremely unlikely that anyone will be able to develop a WTE plant on Guam in the near term. However, we will still estimate the potential energy that could be produced from waste in Section 3.

\footnotetext{
${ }^{47} \mathrm{PL}$ 25-175 is available online, http://www.guampowerauthority.com/special/documents/PL25175 _prohibitIncinerator_plandocs.pdf, accessed on 2/1/2011.
} 


\section{Energy Efficiency and Renewable Energy Opportunities}

Guam represents a high priority location for the development of an integrated energy plan due to its strategic importance to the U.S. military, high energy costs, dependence on imported fossil fuel, and the expected future pressure on the island's energy resources from the planned increase in military and civilian populations.

There are many energy efficiency and renewable energy opportunities for Guam. This section outlines the opportunities that have been identified based on the initial assessment. However the Task Force will need to determine where priorities lie and which opportunities will need to be considered further. The initial opportunities identified are summarized in Table 1. Energy Efficiency and Renewable Energy Opportunities and Potential Impacts.

This section of the report provides information on various opportunities as they relate to developing a strategic plan. Specific savings are difficult to quantify due to the amount of data available at the time of the site visit. Savings could be calculated based on energy audits from private industry and scaled up across the sector, or more detailed audits could be conducted to determine specific savings. The areas of opportunities presented in this section are based solely upon observations made during the site visit conducted by the NREL team while on-island the week of October 11, 2010.

The energy efficiency and renewable energy opportunities discussed below are:

- Energy efficiency and conservation

- Wind

- Solar

- Geothermal

- Biomass.

\subsection{Energy Efficiency and Conservation}

The opportunities that have been identified for energy efficiency and conservation measures include raising island energy awareness in the various sectors, creating a cool-roof program, and establishing metrics for improvement within the island building codes and equipment standards.

Due to administration changes, it is unclear at this time the direction Guam will take on building codes. It is recommended that a review of the existing building codes and equipment specification standards be conducted by the Energy Task Force, utilizing available technical assistance. The end goal of a building code and specification analysis would be to highlight areas where improvements could be made and where Guam could benefit by changing the building code and standards. Other island nations with energy efficiency standards already incorporated into codes and standards could be used as a model. Energy efficiency integrated into tropical building codes, training, and enforcement are all potential next steps after a review of the existing codes is conducted.

\subsubsection{Raise Island Energy Awareness for Conservation}

Energy audits have been funded on island, most recently, by the Guam Energy Office (e.g. audits of government facilities and homes), the Department of Education (schools), and by GPA and Johnson Controls (e.g. hotels, the airport, etc).

It is recommended that building audit results from the current activities on Guam (e.g. within hotels, schools, government agencies, and homes) be applied to developing a strategy where conservation 
measures are relevant to multiple buildings within a specific sector. For example, hotel audits may indicate the need for better lighting controls; this should be integrated into a strategy to improve controls in all hotels, not just those being audited.

These audits may identify both behavioral and technical improvement and are summarized by sector below.

- Residential

○ Campaigns for local communities, as discussed in more detail in Appendix B

○ Pilot the campaign in Dededo where there's interest and the potential for the largest impact as discussed in more detail in Appendix B

- Commercial

○ Work with various sectors to increase awareness through posters, stickers, fact-sheets, etc.

○ Work with island suppliers and retailers to source energy efficient technologies

- Construction industry

- Provide training for the construction industry on design practices and energy efficiency measures that should be incorporated into new construction and renovations, such as external shading for windows, coating coastal air conditioning unit coils to protect from sea mist, insulation, high SEER air conditioning units, etc.

\subsubsection{Establish a Cool-Roof Program to Improve Efficiency}

DOE's Secretary Steven Chu launched a series of initiatives in July 2010 to encourage cool-roof technologies in the federal government. Secretary Chu has directed all DOE offices to install cool roofs whenever cost effective over the lifetime of the roof, when constructing new or replacing old roofs, and in areas where cool roofs will be beneficial to energy efficiency savings (typically in hot climates).

While these initiatives are targeted at federal buildings, the cool-roof program has materials and resources that would be beneficial to Guam. Cool roofs are roofs that are designed to maintain a lower roof temperature than traditional roofs while the sun is shining, typically through reflectance technologies. Not all cool roofs need to be white, as indicated by the cool-roof tiles in Figure $19^{48}$.

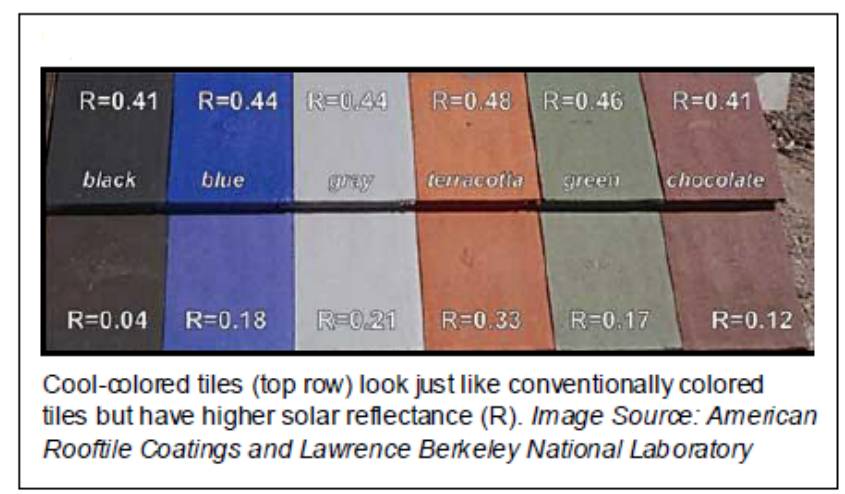

Figure 19. Cool roof tiles in colors other than white Source: DOE

\footnotetext{
${ }^{48}$ DOE, Guidelines for Selecting Cool Roofs, July 2010: http://www1.eere.energy.gov/femp/pdfs/coolroofguide.pdf.
} 
A cool-roof program could be implemented island-wide by using low-cost technologies, such as Elastomeric paint ( $\sim 40 /$ gallon), which would need to be applied to roofs and maintained through a cleaning program (to prevent debris and mold build-up). More information about selecting buildings and implementing a cool-roof program can be found on the DOE website ${ }^{49}$.

\subsubsection{Review and Improve Energy Efficiency Standards to Improve Efficiency}

Building codes were accepted by government officials of Guam; however, energy efficiency should be incorporated into building codes. Building codes should be reviewed and revised to include energy efficiency parameters as soon as possible. The building industry will need time to learn building codes and train personnel to meet these codes, so integrating energy efficiency as early as possible will assist with a faster implementation rate of energy efficiency measures in new construction. Equipment standards should also be reviewed to eliminate/reduce energy intensive equipment, such as window air conditioning units and machinery being imported to Guam. The European EcoLabel scheme or ENERGY STAR ratings are good models to follow for establishing equipment and buildings that meet specific criteria for meeting Guam's energy reduction targets. The EPA Portfolio Manager is useful for managing building stock and benchmarking buildings across a portfolio.

\subsubsection{Consider Alternative Cooling Technologies}

Cooling is one of the highest end users on Guam within all sectors. Considering and implementing promising alternative cooling technologies will assist with reducing fossil fuel consumption related to conditioning indoor spaces. There are a number of options available under the umbrella of alternative cooling technologies.

One lower-cost option in buildings with no requirements for conditioning for moisture control is to install ceiling fans. Where moisture buildup is not a concern it may be possible to utilize natural ventilation (from breezes and open structures of windows, doors, etc.), and ceiling fans, which are in operation only when needed. There may be open structures where this could be a suitable option.

Planting 'green roofs' may also be a lower cost option to consider. Where roofs are flat and structurally sound they can be used to plant vegetation, which not only provides a thermal barrier, but also creates a wicking-type action. The wicking of moisture and heat upwards and out of the building is beneficial in reducing cooling loads in buildings ${ }^{50}$.

A medium-cost option is to install solar air conditioning units. While relatively new on the market, solar air conditioning units are available from a number of manufacturers and suppliers, and have a variety of different installation applications from split wall window units to larger outdoor units. This technology is an efficient type of air conditioner (upwards from a SEER 20) that operates off of a solar photovoltaic (PV) panel, which reduces the energy demand from the grid during times when cooling and conditioning are needed.

A high-cost option to reduce Guam's energy consumption related to space cooling is a sea-water cooling system. This technology is being investigated by private consultants for the U.S. Navy and also by GPA and JCI for the hotel loop in Tumon Bay. The Energy Task Force is encouraged to review the findings of that investigation to determine whether the cost-benefit analysis is in the island's favor.

\subsubsection{Next Steps}

The following next steps are recommended:

1. Continue energy and water audits and apply measures where they are more broadly applicable.

\footnotetext{
${ }^{49} \mathrm{http} / / / \mathrm{www} 1$. eere.energy.gov/femp/features/cool_roof_resources.html.

${ }^{50} \mathrm{http}: / / \mathrm{www} 1$.eere.energy.gov/femp/pdfs/fta_green_roofs.pdf.
} 
Audits have already begun on Guam in specific sectors, such as the airport, Joint Region Marianas sites, and within a few hotels. These audits should continue and, where possible, the measures that are applicable to similar buildings should be gleaned from audit reports and implemented across the building stock. For example, if five of the island's hotels are being audited the measures that are most commonly recommended may be applicable to the remaining hotels. These measures may include improving lighting fixtures and controls; installing low-flow faucets, toilets, and showerheads; or installing thermostatic controls to reduce the energy consumption of air conditioning units. A strategy for identifying and implementing the measures that are most commonly recommended could be a next step, but would require disclosure from the entities conducting the energy and water audits.

2. Begin an energy awareness campaign within the various building sector types.

An energy awareness campaign is a low-cost solution for implementing energy conservation. Pilot projects could be carried out within specific buildings or communities to highlight the impact of the campaign on energy consumption. For example, Dededo has an actively engaged Mayor who may be willing to promote energy conservation. In order to begin an awareness campaign the audience would need to be identified, materials prepared, and launch dates selected. Campaigns are ongoing and need to be renewed every few months to communicate specific messages to target audiences. Materials within a community such as Dededo may include articles in newsletters or the weekly newspaper insert, posters and flyers, stickers for light switches and equipment, and events for children and adults that are fun and educational. A different campaign should be created for each specific audience and may include the following:

a) Hotel staff and guests

b) Medical staff

c) Education staff, teachers, and students

d) Community residents (adults and children).

3. A strategy for implementing a cool roof program should be designed, beginning with identifying buildings to be used as pilots for a cool roof pilot program.

These buildings should be selected following the guidelines established in the materials on DOE's website ${ }^{51}$. Buildings would ideally have engaged facilities management staff who could monitor the energy consumption prior to and after the cool roof installation to indicate any change in energy consumption. Buildings that vary with sector and cool roof application type would be most beneficial to display what is most effective at reducing energy consumption. Facilities in need of roof replacement, particularly if there is a budget for replacement in the near-term, may be most applicable as initial projects. Once this pilot program has been completed the results should be analyzed and the most effective cool roof type should be replicated throughout the building stock, with continued monitoring and savings reports.

4. Create training materials for the design and construction industry to increase knowledge relating to energy-efficient technologies and practices.

Training materials could take the form of curriculum for workshops, handbooks, presentations, websites, and other tools. A training module would need to begin with an assessment of the current level of knowledge and indicate areas of the greatest need for improvement. The audience would need to be assessed so that materials could be tailored to be the most effective.

5. Encourage the use of alternative cooling technologies, where appropriate, within retrofits and new construction.

\footnotetext{
${ }^{51} \mathrm{http} / / / \mathrm{www} 1$. eere.energy.gov/femp/features/cool_roof_resources.html.
} 
Review the results of the salt-water cooling research and determine if implementation in specific industries (e.g. hotels) is beneficial to reducing fossil fuel consumption.

6. Develop a strategic energy plan.

There is great opportunity for policy and technology development in Guam. Through the assistance of Guam's Energy Task Force and the development of a strategic energy plan, policy and technology can be addressed. Ongoing efforts will be needed to support the Task Force on a multitude of levels. Although the Task Force has been established, Guam has currently elected a new governor and administrators; this change can set timelines back. However, Governor Calvo and his administration were quick to be informed and fully support this effort. Maintaining momentum is key to success. The Task Force will require some assistance in deciphering data and directing subcommittee levels while setting goals and objectives. Several deeper dives within technology development and cross-cutting policies will need to be examined to determine best strategies.

7. Develop a policy framework strategy.

Policy is an effective tool in addressing clean energy adoption and subsequent development, and the process of policy development addresses the interconnectedness of social concern. Below is an outline of a policy framework strategy Guam may want to use in developing its strategic plan.

- How is the energy discussion being framed?

- What high-level support is there (federal, territorial, local)?

○ Identify the support; finances, technical assistance, education and outreach activities.

○ How does clean energy address island core values? Find and identify all the connections

- Is there energy literacy in the community, in the business sector, and in the local trades?

- What are the energy goals (federal, territorial, local)?

○ This should cover all sectors; water, agriculture, aquaculture, recreation, tourism

- Stakeholder analysis

- Identifying all barriers

- Social awareness and acceptance

- Financial

- Technical

○ Workforce

- Education

- Surveying current policy

What are Guam's policy nuances?

○ Are they effective?

- Is there a local-territorial government connection?

- Policy analysis

- What technologies support Guam's goals, objectives, and budget?

- What are the policies and programs to support those technologies?

- What existing policies support or hinder Guam's energy goals?

- Implementation and action plan

○ Implementation strategies

- Budgets and timelines

- Measurement and verification

o Re-assessment 
Addressing all these topics through the development of a strategic plan with the appropriate expertise sets a sturdy foundation for assessing opportunities and achieving energy goals.

\subsection{Wind}

Wind energy has the potential to play a major role in supplying electrical energy to Guam. The available wind resource combined with a high level of infrastructure, high energy costs, and a strong federal presence on the island, make wind technology a very viable option. Additionally, several wind assessments have been conducted by both the U.S. Navy and GPA.

Through an Interagency Agreement between the Naval Facilities Engineering Service Center and NREL a $60 \mathrm{~m}$ met tower has been installed on the western boundary of the Ordnance Annex just below Mount Alifan. This measurement station is installed on an island high point andprovides an excellent wind resource reference for the island, the only such reference currently available. The measurement site was installed in September 2008 and thus far shows a very good class 5 resource on the island with a mean wind speed in the region of $7.9 \mathrm{~m} / \mathrm{s}$, with stronger winds during the winter months. A summary of the data collected to date is provided in Appendix $\mathrm{C}$ and clearly demonstrates that the island has a viable resource if an appropriate development site can be identified.

Although not verified, viable wind sites have been identified by GPA for up to $20 \mathrm{MW}$ of installed capacity in a large-scale wind development, with the potential of several smaller, $1 \mathrm{MW}$ to $5 \mathrm{MW}$ scale projects at several locations around the island. Additional large-scale wind development project locations may still be identifiable, primarily on the northeast coast or buttressing eastern ridges on the southern end of the island. However, the identification of the GPA Cotal site, combined with the potential sites on U.S. Navy property provides a key focal area for near-term project development.

In a study conducted by DNV-Global Energy Concepts for GPA, the Cotal site area, which is located just to the north of the Cross Island Road (HWY 17) east of Mount Alifan and the community of Apra Heights. This site could support approximately 10 large wind turbines along two ridges, with a total capacity of approximately $20 \mathrm{MW}$. The site has good road access, is close to a $34.5 \mathrm{kV}$ transmission line, and is within several miles of a substation. The site was reviewed during the NREL island visit and proved to be a good location. The turbines would be installed upwind from several homes and a larger potential development area. The site sits directly south of the Leo Palace Resort and although not close, will be clearly visible from the resort. The elevation of the site is around $200 \mathrm{~m}$, which puts it only approximately $50 \mathrm{~m}$ lower that the island high spots and approximately $3 \mathrm{mi}$. from the U.S. Navy met mast, which shows an annual wind speed in the area of $8 \mathrm{~m} / \mathrm{s}$. Land in this area is primarily owned by the Department of Agriculture with several smaller private holdings.

As stated, several other sites have been investigated though various assessments, including on the south end of the island, along the main island ridge near the U.S. Navy magazine, on the Apra Harbor breakwater, land to the south of the Cross Island Road (HWY 17) in the area of the Cotal site, and some locations along the northern and northeastern coast. Most of these sites could be given additional consideration although all of them have one or two critical siting shortcomings, such as a reduced or more turbulent wind resource, limited local transmission infrastructure, or more complex siting, indicating that none of the sites identified thus far seem to be as viable as the Cotal site.

More information regarding the wind assessments that have been conducted, including a summary of data collected through the U.S. Navy-sponsored project and the GPA-funded studies is provided in Appendix C.

\subsubsection{Key Challenges to Wind Development}

There are several key elements that need to be taken into account when considering the deployment of wind technologies. In the context of Guam, environmental impact, specifically relating to threatened 
species and ground cover, radar/communications impacts, social acceptance, and the impact of wind on grid stability will be critical components for wind deployment on the island.

The environmental and radar impacts of wind deployment are two of the most critical due to their binary nature in that if the proposed site and/or turbine is likely to have adverse environmental or radar impact, the site is likely non-viable. Grid impacts are primarily technical in nature and can be addressed using a number of techniques, many of which will have a cost impact on the project. Due to the high cost of conventional power generation it is likely that even with the additional cost of power control system modifications, the wind project will remain financially viable, reducing the likely impact of this barrier.

Social acceptance of wind technology could become a major issue in successful project development and thus must be carefully orchestrated. Due to the small size of Guam and generally high population density, any development site, primarily in the north, will result in a social impact. This impact will likely be in the form of noise and visual clutter; although infra-sound, adverse health, and flicker (the strobe effect of shadow caused by the wind turbine blades) could also be brought up as concern. Local opposition could develop around these issues if people felt that the site of the wind turbines would negatively impact island life. This is especially true if the owners of the Leo Palace Resort felt that a proposed project at Cotal would impact their business model, as this could represent a funding mechanism for a local anti-wind development advocacy group.

Generally speaking, project implementation is greatly improved if the local community feels that the project provides community or personal benefit. The fact that the wind project can represent a means to reduce the cost of power to all of the island's communities and that it would reduce dependence of imported energy sources will decrease the likelihood of potential community criticism; however the control of this communication will be critical for eventual project success. Examples of wind developments on other islands, and input from residents of those communities regarding perceived and actual impacts, can assist in addressing potential societal concerns.

\subsubsection{Infrastructure}

The infrastructure for the development of large scale wind deployment on Guam, although problematic, is not seen as a critical issue. Although this may differ for other island locations, in the context of a potential project at Cotal, the road, transmission, general construction, and shipping infrastructure onisland is adequate for large wind turbine implementation.

The only current limiting factor is the availability of a heavy lift crane to support turbine installation. It could be that such a device will be available on-island due to the pending military-driven infrastructure improvements, or a crane will have to be shipped to the island. In either case this issue will reflect on project economics but will not impact the technical viability of the project.

Typhoons do pose an important risk in the use of wind technologies. All larger wind turbines are designed to stop operating in high wind conditions, meaning that in all except the most extreme cases storm-related damage is going to focus on that caused by airborne debris, typically to the turbine blades. The other potential issue would be the wind loading on the turbine structure exceeding the tower or foundation design loads, which are controllable factors, although they can cause increased implementation costs representing an engineering design issue. Although there has not been much experience with large turbines in the Pacific, a number of turbine installations in the Caribbean have not reported major issues, including a small system of four turbines installed at Guantanamo Bay on the eastern end of Cuba, an area with common hurricane (typhoon) activity.

Looking at the implementation of turbines installed in areas with known typhoon or extreme weather events, consideration must be given to both turbine selection and an assessment of the risk for the turbine structure, which may lead to the purchase of insurance. Every large wind turbine is designed 
around an international standard for wind intensity, provided in a class rating. The class rating will also impact the size of the wind turbine rotor, which will have an impact on the resulting energy generation from the turbine.

At least two manufactures have a typhoon-rated wind turbine, although it is not clear if this relates to Class V typhoons. Additionally the wind turbine manufacture Vergnet makes a $220 \mathrm{~kW}$ turbine that is designed to be lowered during potential typhoon events and is production testing a larger turbine where the rotor of the turbine is removed. In all cases however, the purchase of insurance, or in cases of selfinsured companies, an assessment or risk is used to assess the appropriateness of installing wind in any environment.

Historically insurance companies have not been willing to provide insurance for turbines in Class V typhoon areas, but with the development of turbines rated for typhoon environments, it may now be possible to do so. In any case, one of the first steps in the development of potential projects will be to contact wind turbine manufactures, either informally or through a competitive process, to better determine what products are available; survival wind speed, as well as typhoon experience, should clearly be one of the key competitive requirements.

\subsubsection{Next Steps}

The following next steps are recommended:

1. Conduct a detailed wind development assessment for the Cotal site.

With the expectation that the development of this site will be conducted through a competitive request for tender, the more information that is available about the site will result in improved project design and economics. This activity would lay the groundwork by conducting all of the initial screening studies that will be required for site development. Other elements of the study would include:

- Resource assessment combined with data correlation. This would include the installation of a $50 \mathrm{~m}$ or $60 \mathrm{~m}$ met mast for a minimum of one year. It will also be critical to an overall analysis to correlate the wind resource data with the U.S. Navy Mt. Alifan tower. If at all possible, both met towers should be installed for a full overlapping year.

○ Land title assessments

- Initial environmental impact assessments

○ Geotechnical assessments

○ Initial grid interconnection assessment

- Initial social acceptance documentation (noise and visual simulations)

○ Typhoon risk analysis and impact of economics of wind generation.

This activity would be followed by more detailed feasibility and economic assessment of the project. Aside from the resource assessment, these activities should cost approximately $\$ 50,000$. Additionally, costs of resource assessments can be significantly reduced if the met tower is classified as a temporary structure and not subjected to typhoon building codes.

2. Support a direct collaboration between GPA and the U.S. Navy regarding wind project development on both military and non-military property. 
The military and GPA have overlapping activities that should be coordinated to spur collaboration. Additionally, the installation of wind turbines will have some impact on military operations, so these issues should be addressed at the onset of the project.

3. Initiate an active social acceptance outreach and education activity around wind.

For successful project development it will be critical to get ahead of the information around the deployment of wind technologies on Guam. This would include the quantifying of potential impacts, such as job creation, economic development, and consumer savings while developing information regarding potential negative impacts, such as conducting a noise impact assessment and visual simulations. All of this information should be publically available with open forum discussions conducted by GPA or another organization to identify and address potential issues. If at all possible this should be implemented during the initial assessment phase (within the next year) to get ahead of the development of inaccurate preconceived notions. This activity and the information generated through it should not directly advocate for a wind project, but should provide fair and balanced information on the impacts of wind development.

4. Expand investigation of additional potential sites for community and large wind development.

Given the potential savings that could result from expanded wind deployment on the island and clear access to a viable wind resource, efforts should be made to identify additional potential sites on Guam for expanded wind development in addition to expanded collaboration on sites being considered by the U.S. Navy. This would include an island-wide screening study using land ownership, resource through an island-wide wind map, environmental sensitivities, and known development limitations. This would allow the potential identification of additional locations that could be developed at varying degrees of cost. This information would then be used to support longer range strategic planning.

5. Conduct an initial screening of potential turbine options for typhoon environments.

If wind development is to be seriously considered, this would include both an assessment of available equipment as well as a risk assessment considering the frequency of typhoons of different classes. Through turbine manufactures or independently, insurance companies could be contacted to determine if insurance policies for wind turbine projects in Guam could be obtained and, if so, at what cost.

\subsection{Solar}

Solar energy technologies are often broken down by solar thermal and solar PV applications. Solar thermal technologies capture energy from the sun to heat a fluid or air, which is generally used to heat water. Solar PV technologies are used to capture the photons from the sun to create electricity. These two technologies and their applications are outlined in this section.

\subsubsection{Solar Thermal}

Solar thermal technologies, also known as solar hot water, are typically low- to medium-cost and easy to install. Conversations with several hotel engineers on Guam have indicated that the second largest energy cost for hotels is hot water (after air conditioning and chiller loads). The current practice on Guam is to heat water using diesel fuel, although some hotels on Guam are using vegetable oil to heat water. Solar hot water is a low to medium cost application that should be considered within the larger industries where hot water consumption is high. 
Figure 20 shows a common solar thermal system used for hot water heating ${ }^{52}$.

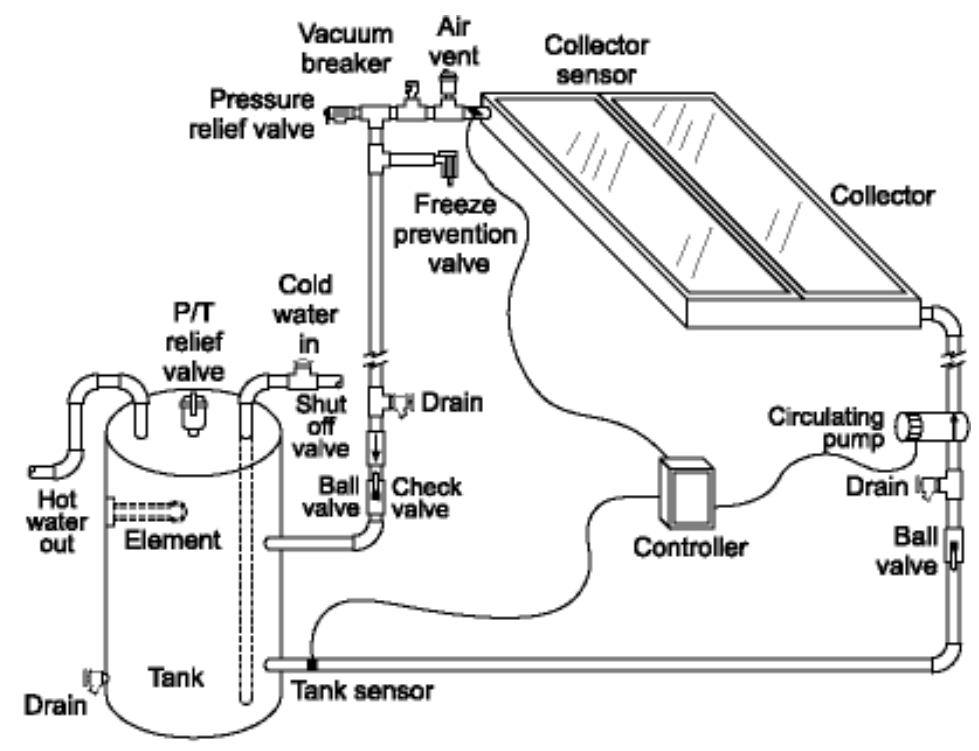

Figure 20. A common solar thermal system Source: NREL

A solar collector captures the heat from the sun and then gravity typically draws a fluid out of the collector to act as a heat exchanger to transfer the heat to another material, such as water in a tank. Pressure relief valves and circulation pumps are needed to maintain pressure and keep the fluid moving through the distribution system. Basically, these systems convert sunlight to thermal energy by absorbing the sun's radiation to produce heat which is transferred to water. Like most technologies, there are several types of systems that follow this basic operation and can be applied to various applications in both residential and commercial sectors. This technology works well in recreational settings such as pool heating.

Solar thermal heating works well in most situations. The system efficiency is improved with the use of evacuated tubes, however even low-tech collectors are able to generate a low grade heat, which offsets the amount of energy required to heat water in most applications. By reducing the amount of hot water being generated through conventional forms of heating, the demands on fossil fuels can be lessened.

Solar thermal technologies should be considered for hotels, hospitals, laundromats, assisted living facilities, and residences where hot water demands offset the capital costs of installing solar thermal panels.

Panels should be installed where there is exposure to the sun without shading from buildings or vegetation. They should also be installed in locations where they will not be vandalized or tampered with, and they should be installed according to building regulations, plumbing, and access codes ${ }^{53}$.

\footnotetext{
${ }^{52} \mathrm{http} / / /$ www.nrel.gov/docs/gen/fy04/36831m.pdf.

${ }^{53} \mathrm{http}: / /$ www.nrel.gov/docs/fy99osti/26579.pdf.
} 




Figure 21. Solar hot water, Hickam Air Force Base Source: NREL/PIX 09188

As a comparitive case study, the United States Coast Guard in Honolulu, Hawaii, installed 62 active/direct solar thermal system units in 1998 . The average cost at that time was $\$ 4,000$ per system with an additional discount of $\$ 800.00$ from the utility. The utility had previously initiated a rebate program as an incentive for solar hot water installation for residences. The energy savings was 3,008 $\mathrm{kWh}$ per year with a demand savings of $1.62 \mathrm{~kW}$ per house ${ }^{54}$ Figure 22 refers to the average hourly power per household within a 24 hour period.

With the current market, solar thermal systems have reduced significantly in price and increased in efficiency. With the end-use statistics mentioned in Section 2.2.3, both commercial and residential solar hot water systems are opportunities for fossil fuel replacement and energy savings.

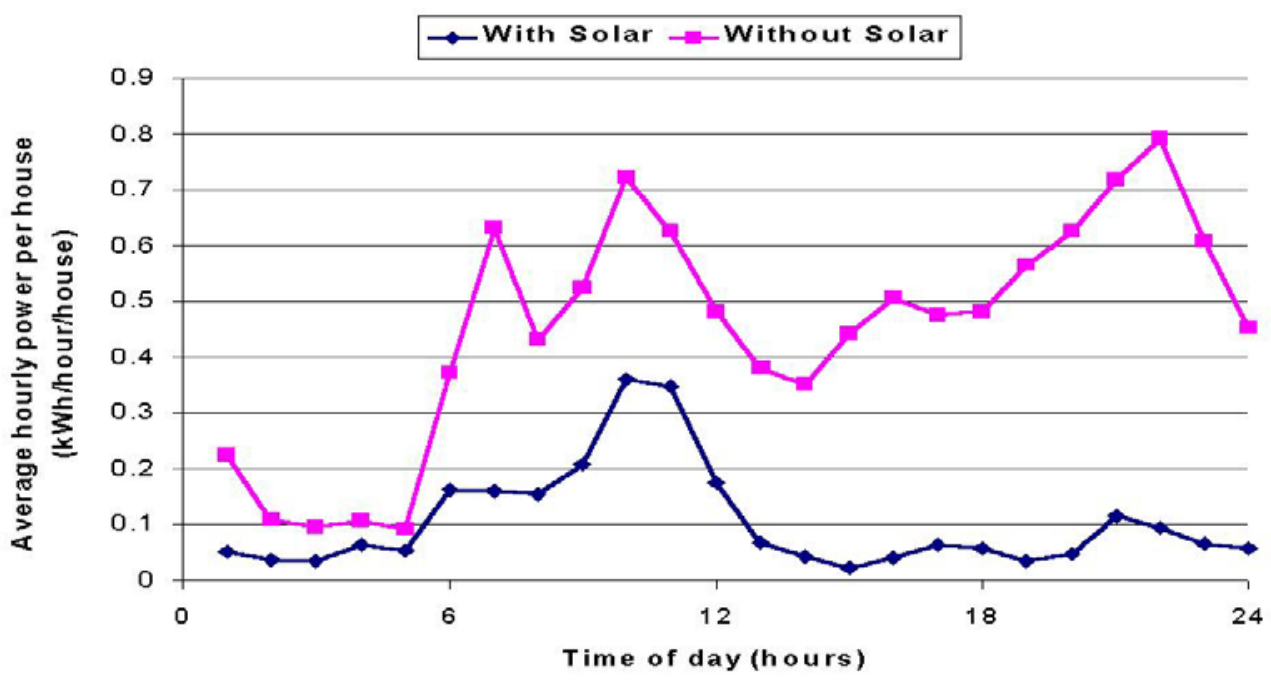

Figure 22. U.S. Coast Guard housing, Honolulu, Hawaii Source: NREL

\footnotetext{
${ }^{54}$ Walker, A., Christensen C., and Yanagi, G., "Time-of-Use Monitoring of US Coast Guard Residential Water Heaters with and without Solar Water Heating in Honolulu, HI" ASME International Solar Energy Conference 2003, March 2003, Kohala Coast, Hawaii.
} 


\subsubsection{Solar PV}

Winzler and Kelly, on behalf of GPA and in support of GPA's Integrated Resource Plan (IRP), evaluated various Guam properties for potential use as a PV solar power plant (see Figure 23). This evaluation will be included as an attachment to GPA's upcoming Invitation for Multi-Step Bid (IFB) for renewable energy resources to provide guidance and background information to potential solar power plant developers. Solar power is just one of several options that will be considered under the IFB.

The criteria that were used to evaluate sites were developed in conjunction with GPA and R.W. Beck, which is also providing consultation services in support of GPA's IRP. It should be noted that this evaluation is only presented as a guide and does not establish any specific requirements that potential solar power plant developers must follow to satisfy the requirements of the IFB. The criteria and resulting evaluation of sites contained herein are merely presented as a starting point for potential developers to utilize as they desire. It is also important to note that no land owners of sites evaluated herein have been contacted nor has any effort been made to evaluate potential real estate or other costs.

In general, the scope of work for this evaluation included the following:

- Investigate between three and six sites outside of DOD property. Note: R.W. Beck provided footprint information of 60-80 acres per $10 \mathrm{MW}$ plant, to which GPA gives preference

- Review topological data, access roads, proximity to GPA transmission/distribution systems, other improvements, and land use and property ownership (based on publicly available information at the Department of Land Management, no title reports required)

- Submit Technical Memorandum that describes advantages and disadvantages for the potential solar development locations, including potential plant sizes in investigated areas. 


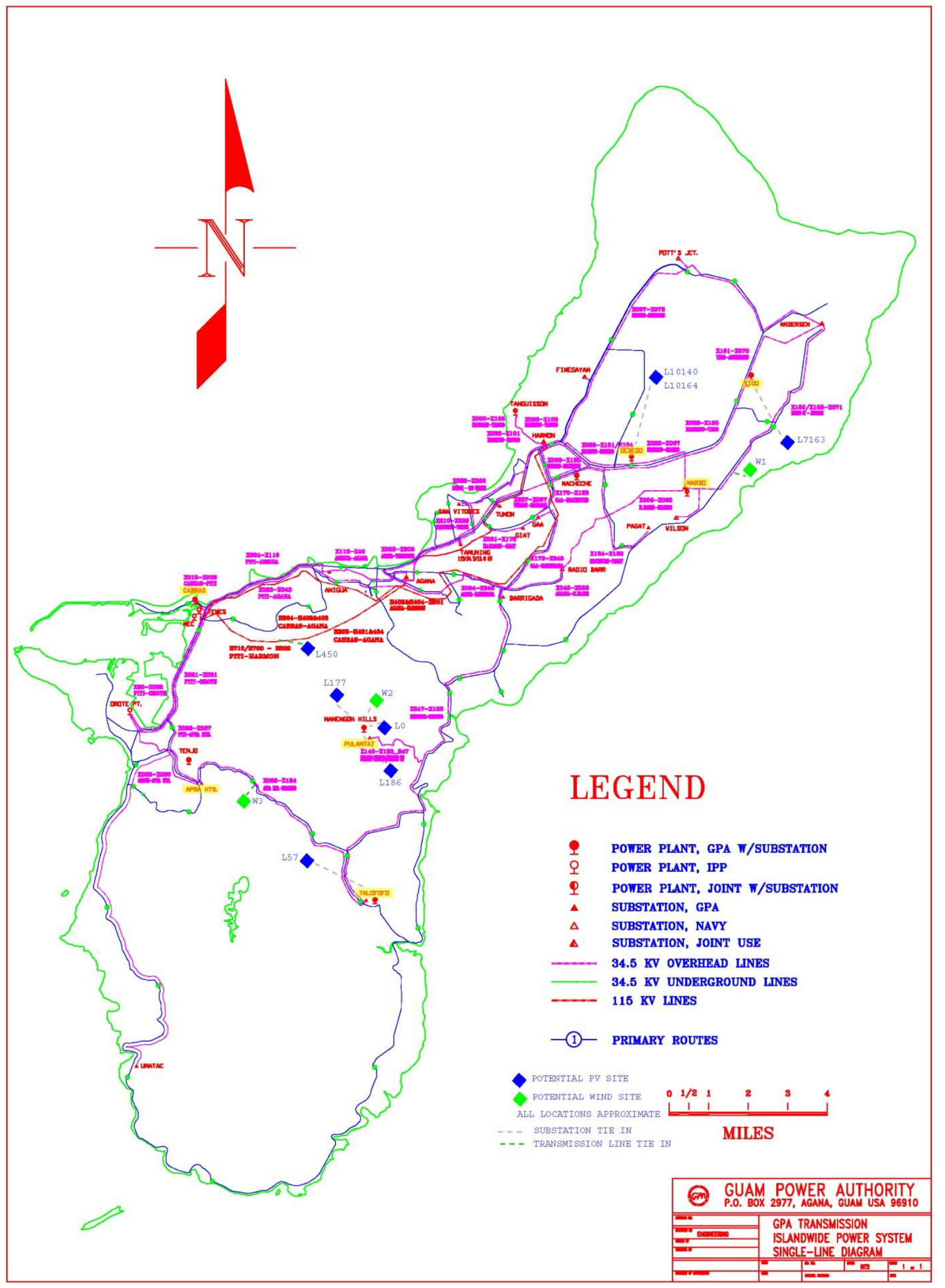

Figure 23. GPA transmission system map with potential solar and wind locations marked Source: GPA 


\subsubsection{Next Steps}

The following next steps are recommended:

1. Create a subcommittee within the Energy Task Force to address all possibilities of policies and programs for solar hot water systems for all sectors.

2. Consider a renewable energy interconnection study.

3. Conduct field assessments of each site to determine how many acres of each site can actually accept solar arrays, and to determine the potential energy output (in MWh) from those more detailed solar plants assessments.

The top seven parcels for installing solar arrays identified during this study are shown in Table 8 . The third column is an estimate of the total amount of the array output at a conservative (relatively low) value for the array density, and the fourth column is an estimate at an optimistic (relatively high) value. Assuming every acre of every lot could be populated with PV modules, the potential for solar PV could range from $315 \mathrm{MW}$ to $631 \mathrm{MW}$.

Table 8. Top Seven Sites Identified for Solar PV

\begin{tabular}{crrr}
\hline Lot Number(s) & \multicolumn{1}{c}{ Total Size } & 100-kW / acre & 200-kW / acre \\
\hline L450-R3 & \multicolumn{1}{c}{ acres } & kW PV & \multicolumn{1}{c}{ kW PV } \\
L177-4-R2 & 1,125 & 112,450 & 224,900 \\
L7163 & 1,072 & 107,200 & 214,400 \\
L10140-R5 and & 416 & 41,550 & 83,100 \\
L10164-R3 & 191 & 19,070 & 38,140 \\
L57-2 & 169 & 16,890 & 33,780 \\
L0 & 111 & 11,090 & 22,180 \\
L186NEW-1 & 72 & 7,150 & 14,300 \\
Totals & 3,154 & 315,400 & 630,800 \\
\hline
\end{tabular}

\subsection{Geothermal}

Due to the enormous need for clean baseload generation and the increasing need for energy diversity, geothermal potential must be assessed and determined to be a likely technology to implement or not. Baseload geothermal power would be a tremendous asset if it could be found and developed on Guam.

A team from NREL and the U.S. Navy's Geothermal Program Office in China Lake, California, conducted a reconnaissance assessment of the geothermal potential of the island for DOD in April 2010.

Guam has no obvious surface features suggesting geothermal potential and has never been the focus of a geothermal exploration campaign, nor even a rigorous geothermal assessment. Guam lies on a regional trend of high heat flow, the Izu-Bonin-Mariana (IBM) volcanic arc system. However, while the central and northern portions of the IBM arc are volcanically active, Guam is not, and has not been, for millions of years. Nonetheless, active submarine volcanism occurs in deep water tens of miles west of Guam.

The NREL/U.S. Navy team uncovered a reliable report of a steam vent in an abandoned limestone quarry on the southwest corner of Tumon Bay in fall 2010. The team located the quarry and spoke extensively with Professor John Randall, University of Guam (retired) who visited the quarry in the 
early 1970 s specifically to observe the steam phenomenon. The evidence of the steaming vent, and a report of a hot water well in the Ylig Valley, suggest that geothermal fluids are present in the subsurface on Guam. Certainly, there appears to be enough information to warrant further investigation and exploration for geothermal systems on Guam.

\subsubsection{Next Steps}

The U.S. Navy is conducting an assessment to identify potential geothermal locations using Light Detection And Randing (LIDAR) technology during spring 2011. The U.S. Navy has committed funds to drill temperature gradient holes starting in summer 2011. The specific locations where the temperature gradient holes will be drilled will be guided by the results of the on-going LIDAR study.

\subsection{Biomass}

Biomass is generally defined as any organic feedstock available on a renewable basis. Typical biomass resources include wood and wood waste, MSW, landfill gas (LFG), agricultural and crop residues, human solid waste, and animal manures. One of the primary benefits of biomass is that feedstocks can be stored, thus allowing for baseload, dispatchable generation. If using a biofuel, such as biodiesel, the fuel can be used directly in the existing equipment, thus allowing for renewable fuel switching at minimal capital cost.

Biomass resources that are potentially suitable for Guam include:

- MSW electricity generation Biodiesel or straight vegetable oil production and use in existing fuel oil boilers or engines

- LFG capture for energy recovery

- Anaerobic digestion to generating biogas at waste water treatment plants and small-scale digesters for converting animal manure to biogas

- Dedicated feedstock productionto produce solid or liquid biofuels

During the site visit, the NREL team evaluated potential opportunities to develop each of these options.

\subsubsection{Waste-to-Energy}

The generation and disposal of MSW presents challenges for most communities, but especially islands. Converting MSW to energy is one option that many communities have either undertaken or are considering. There are several challenges to developing a WTE facility on Guam, not the least of which is a law that was passed by the legislature in 2001, that effectively prohibits WTE projects in Guam. These challenges were outlined in Section 2.2.5 of this report.

As discussed in Section 2.2.5, our best estimate is that Guam produces approximately 111,000 tons of MSW per year, of which 94,321 tons are deemed to be potential feedstock. There may be other feedstocks available, such as tires, sludge from wastewater treatment plants, green waste, and some small quantities of agricultural residues. As these resources have not been quantified, and to do so is beyond the scope of this report, they are not included in the following analysis. There is also the potential for increased waste generation associated with the DOD build-up. These numbers must also be quantified for future efforts.

As shown in Table 9, we estimate that 94,321 tons per year of MSW would be sufficient to fuel a 4.7 MW to 7.0 MW (net output) plant with an $85 \%$ capacity factor. The actual generation will be highly dependent on the selected technology, the overall composition of the feedstock, how the feedstock is handled and prepared (e.g. is it processed into refuse derived fuel or used as is?), system design, and overall operating conditions. 
Table 9. Summary of WTE Potential

\begin{tabular}{|l|l|}
\hline $\begin{array}{l}\text { Total Waste } \\
\text { (tons/year) }\end{array}$ & 110,967 \\
\hline $\begin{array}{l}\text { Estimated non } \\
\text { combustibles (\%) }\end{array}$ & $15 \%$ \\
\hline $\begin{array}{l}\text { Combustible waste } \\
\text { (tons/year) }\end{array}$ & $\mathbf{9 4 , 3 2 1}$ \\
\hline Capacity Factor & $85 \%$ \\
\hline Tons/operating day & 304 \\
\hline $\begin{array}{l}\text { Net power - low } \\
\text { efficiency (MW) }\end{array}$ & 6.5 \\
\hline $\begin{array}{l}\text { Net power - high } \\
\text { efficiency (MW) }\end{array}$ & 9.7 \\
\hline $\begin{array}{l}\text { Net energy - low } \\
\text { efficiency (MWh) }\end{array}$ & 48,103 \\
\hline $\begin{array}{l}\text { Net energy -high } \\
\text { efficiency (MWh) }\end{array}$ & 84,889 \\
\hline
\end{tabular}

The value for "low efficiency" in Table 9 is based on an assumed yield value of $510 \mathrm{kWh}$ per ton of MSW processed. This is equivalent to a typical mass burn combustion plant today. The value for "high efficiency" assumes a conversion factor of $900 \mathrm{kWh} /$ ton MSW. This is equivalent to what some manufacturers of advanced conversion technology gasifiers and plasma units are claiming to be able to obtain from their systems.

It should be pointed out that there are no commercial advanced conversion technology WTE projects operating in the United States, although there are several reported to be operating in Asia and Europe. Of the commercially-viable WTE systems that are operating in the United States, nearly all (if not all) of the plants use either stoker or fluidized bed combustion technology. Combustion technology is fully commercial and lenders are willing to make loans to well-structured projects that have a guaranteed supply of MSW and a power purchase agreement with a credit-worthy customer.

The numbers in Table 9 above assume that $15 \%$ of the output from the plant will be used for parasitic loads. In terms of net capacity, NREL estimates that between 6.5 MW and 9.7 MW of power could be provided from waste on Guam. Because WTE can be operated 24/7, a WTE plant produces more energy over a year than an equivalent wind or solar plant. So a $6.5 \mathrm{MW}$ WTE plant would produce approximately the same amount of energy each year as an $18 \mathrm{MW}$ wind farm (at $35 \%$ capacity factor), or $54 \mathrm{MW}$ of solar at an $18 \%$ capacity factor. The WTE plant would take up far less space as well and could be co-located at the Layon Landfill.

The estimated capital cost of this project is $\$ 102$ million. This is calculated based on assumed capital costs of $\$ 400,000$ per ton per day. For comparative purposes, the 16.5 MW (net) WTE plant under development in the U.S. Virgin Islands is estimated to cost $\$ 160$ million $(\$ 457,000 /$ ton/day). This cost includes setting up two material recovery facilities for converting MSW to refuse derived fuel through a proprietary process called WastAway. Material from the two WastAway plants will then be sent to the centralized WTE plant. The developer states that the WastAway process creates a product that is dry and has a Btu content of 7,500 Btu/lb. The energy content of Guam's waste stream has not been reported but we estimate it to be similar to the U.S. average of 5,900 Btu/lb. 
For Guam, NREL conducted a preliminary economic analysis of a low-efficiency WTE plant. Results indicate that if a private developer were to come in and build, own, and operate the plant, and the developer was not paid a tipping fee, electricity would need to be sold to GPA for $\$ 0.26 / \mathrm{kWh}$ (escalating at $3 \%$ per year) to make the project economically attractive. For the developer to be able to sell power to GPA at $\$ 0.15 / \mathrm{kWh}$ (with a 3\% annual escalation), the developer would need to receive a tipping fee of approximately $\$ 75 /$ ton.

It must be pointed out that the numbers above are preliminary and need to be investigated in greater detail. We are using rule-of-thumb numbers and there are many companies and technologies available. It may be possible for a developer to make the economics work using various technical and economic configurations. The best way to determine what the market can deliver is for GPA to develop a request for proporals (RFP) for WTE (after regulatory/legal issues are addressed) and see what bids are received.

The major barrier to WTE is PL 25-175. Until Guam changes the law and allows WTE projects to be developed, there is little to be gained through speculation on various technologies, configurations, technical performance, and cost. A more immediate short term need would be to focus on legislation that would allow flexibility on the development of WTE plants, bearing in mind local desires for clean technology and debt repayment on Layon Landfill. This could be an action for the legislative subcommittee of the Energy Task Force.

\subsubsection{Biodiesel or Vegetable Oil}

The use of biodiesel or vegetable oils in diesel generators and boilers is gaining wider acceptance around the world. The ability of biodiesel to be used within existing utility diesel infrastructure is a compelling reason for exploring this option. There are minimal capital costs associated with using a biodiesel or vegetable oil/diesel blend in existing diesel or residual fuel-oil-fired generators, combustion turbines, or boilers. Biodiesel blends of $2 \%$ up to $20 \%$ can typically be used in existing equipment with only minor modifications. There have been several testing programs, particularly in Hawaii, aimed at firing $100 \%$ biodiesel in utility-scale boilers, turbines, or generators. Several utilities have been running biodiesel in standby generators as a way to implement peak load reduction and reduce emissions associated with running the generators beyond their annual permitted hours.

The use of $100 \%$ biodiesel in utility-scale generators is being pioneered in Hawaii, where there are at least three different projects underway:

1. Hawaiian Electric Company (HECO) recently completed co-firing tests of various blend percentages of petroleum diesel and biodiesel fuels at the 90 MW Kahe Power Plant. On January 28,2011 , HECO issued a press release stating that they successfully tested $100 \%$ biodiesel in Kahe at the full load of $90 \mathrm{MW}$. Tests will be continuing for the next several months. The next test will demonstrate 24-hour operation on biofuels. One of the major observed results of the tests is that the use of biodiesel reduced opacity, NOx, and criteria pollutant emissions below the levels associated with ultra low sulfur diesel fuel ${ }^{55}$.

2. Maui Electric Company (MECO) uses biodiesel to start up and shut down two of its generators. MECO is also conducting tests to determine the long term impact of using biodiesel on heat rates, emissions and engine reliability.

3. HECO's Campbell Industrial Park Generating Station, Combustion Turbine Unit 1, is a new (2009) $110 \mathrm{MW}$ combustion turbine unit designed to run on $100 \%$ biodiesel. Renewable Energy

\footnotetext{
${ }^{55}$ HECO Press Release. Available online at: http://www.heco.com/portal/site/heco/menuitem.508576f78baa14340b4c0610c510b1 ca/?vgnextoid=9fbfb7ba04ecd210 VgnV CM1000005c011bacRCRD\&vgnextfmt=default\&cpsextcurrchannel=1. Accessed 1/31/2011.
} 
Group of Iowa presently has a contract to supply three to seven million gallons of biodiesel per year. All biofuel procured by HECO must meet stringent sustainability guidelines.

HECO has determined that the use of biodiesel is its most cost-effective option for complying with Hawaii's renewable energy targets.

Biodiesel is made through the transesterification of animal fats or vegetable oils. The feedstock can come from waste sources, such as grease from restaurants, or from virgin sources, such as oil seeds, coconut, palm, jatropha, or algae. In Hawaii, biodiesel is procured from the mainland and Malaysia, though long term plans call for production of feedstocks locally.

The major issue to evaluate whether biodiesel makes sense for Guam is supply and cost. The amount of waste grease produced in Guam is not known as there is no known inventory of fats, oils, and greases. However, anecdotal evidence suggests the figure is on the order of 10,000 gallons per month ${ }^{56}$. There are also some concerns over shelf life, with some evidence suggesting biodiesel can begin to break down after six months. This concern can be addressed by ensuring that the supply is evenly matched to potential demand.

Also, there are significant costs associated with converting vegetable oils to biodiesel. The process requires methanol and lye, both of which would need to be imported from the mainland. There is also a question over economies of scale, and it is likely that the supply of feedstock in Guam is too limited to warrant construction of a biodiesel plant.

There is limited agricultural land available for in Guam for production of commercial quantities of oil. Dr. Marutani from the University of Guam has been conducting research on the oil yields of Jatropha and Calophyllum and has planted test plots of these species. The research is on-going and focused primarily on the quality of the oil. Research on production costs, available land and potential yields has not yet been undertaken.

While not likely to be a significant source of fuel for Guam, the use of waste oil in boilers and engines should be explored further, as should the economics of producing oil from local plants.

\subsubsection{Landfill Gas}

There are three potential locations on Guam where LFG-to-energy might be possible. The sites include Ordot Dump, the DOD landfill on Anderson Air Force Base, and the landfill on the U.S. Navy base at Apra Harbor.

In 2004, a study on the potential for LFG generation at Ordot was conducted ${ }^{57}$. The study used the EPA's LandGEM model to estimate potential methane generation and decay rates over time. This was a first level analysis utilizing a number of assumptions and estimates due to lack of specific data for Guam and Ordot. The model results indicated a rapid falloff in methane production after about 10 years. Under a middle-of-the-road scenario, the authors estimated that there was sufficient gas for nearly $3 \mathrm{MW}$ of production in 2007, but that by 2017 there would only be sufficient gas for $150 \mathrm{~kW}$.

There is a great deal of uncertainty over the potential for LFG capture at Ordot. The authors conclude that any LFG-to-energy plant would likely need to be sized below $500 \mathrm{~kW}$ to have a greater chance of

\footnotetext{
${ }^{56}$ Dr. Mari Marutani of the University of Guam conducted a survey of reasturants. Her data indicate approximately 3500 gallons/month. However, this survey did not capture all of the sources of grease. There are several grease haulers and pumpers on Guam and they indicated that the value of 3500 gallons/month is low compared to the actual volumes.

${ }^{57}$ Estimation of Potential Yields of Landfill Gas from the Ordot Dump. Duenas \& Associates and URS Corp. July 2005. Accessed online at: http://guamsolidwastereceiver.org/pdf/RFP\%20SWD001-11\%20-\%201b\%20\%20Est.\%20of\%20Poten.\%20LFG\%20Yields\%20Ordot\%20Dump.pdf accessed January 29, 2011.
} 
running beyond five years. Given that most projects need to run for at least 10 to 15 years to pay off the investment, the willingness of an investor to finance a LFG project in Guam is questionable.

The authors suggest that if the landfill were capped and proper drainage installed there could be the potential to slow down the landfill decay rate and prolong gas generation. Given the high degree of uncertainty over the data and the model results, it is likely that the most economic option will be a capand-flare system.

\subsubsection{Anaerobic Digestion}

As part of the military build-up, significant improvements are planned to Guam's wastewater treatment infrastructure. The designs for the new sewage treatment plants have not yet been finalized. As the design team moves forward, the potential for installing anaerobic digesters as part of the improvements should be studied. The U.S. EPA estimates that between $491 \mathrm{kWh}$ and $525 \mathrm{kWh}$ of energy can be produced for each million gallons of sewage flow ${ }^{58}$.

The Northern District Wastewater Treatment Plant (NDWTP) is presently treating about 6 million gallons per day (MGD) of flow. At one point this facility did have working anaerobic digesters although these have not been used due to disrepair for about the past 10 years. The NDWTP was designed to handle about 12 MGD of flow.

The Hagatna Waste Water Treatment Plant is designed to handle about 12 MGD and presently handles about 4.4 MGD. The U.S. Navy owns and operates a treatment plant at Apra Harbor, which is designed to handle 4.3 MGD and presently handles about 2.9 MGD. The Agat-Santa Rita plant is designed to handle .75 MGD although current flows into the plant presently exceed this design capacity. There are several other smaller plants that all treat less than 1 MGD.

To understand the potential, NREL assumed current sewage flow of $15 \mathrm{MGD}$. If $500 \mathrm{kWh}$ can be produced per million gallons, the current potential on Guam is for 7,500 kWh/day. Assuming a capacity factor of $90 \%$, this equates to about $350 \mathrm{~kW}$ of potential capacity at Guam's waste water treatment plants. While not a large amount, the economics should be explored to see if this option warrants further development.

\subsubsection{Small-scale Biomass}

There may be niche opportunities within the agricultural sector for small-scale biomass or biogas utilization. This opportunity is lower priority in terms of generation potential. The University of Guam Department of Agriculture and the U.S. Department of Agriculture's (USDA) National Resources Conservation Service (NRCS) are best situated to lead future efforts in this area.

\subsubsection{Production of Dedicated Biomass Feedstocks}

The production of dedicated biomass feedstocks for biofuels or for use in a solid fuel plant has not been investigated in detail. Many island communities are investigating this option. For example, there are several companies and groups in Hawaii that are developing plans for locally grown biofuels production.

However, based on the initial site visit, NREL believes that growing bioenergy feedstocks on Guam will present the following challenges:

- Small land area with steep hills, rocky cliffs, and densely growing jungle

- There is not a large agricultural industry in Guam, and there are very few commercial operations

\footnotetext{
${ }^{58}$ Opportunities for and Benefits of Combined Heat and Power at Wastewater Treatment Facilities; Eastern Research Group and Energy and Environmental Analysis, U.S. Environmental Protection Agency: Washington, DC, 2007; Available online at: http:/www.epa.gov/CHP/documents/wwtf_opportunities.pdf (accessed on March 28, 2011).
} 
- There are a large number of small-scale farmers with acreages from 1 to 50 acres

- NRCS and local agricultural interests would like to promote food production instead of energy, given the limited agricultural land available

- Clearing overgrown forestland to establish energy plantations presents risks from unexploded ordnances; the first cost of establishing a plantation will be very expensive.

\subsubsection{Next Steps}

Biomass utilization and WTE should make up some component of a wider energy strategy for Guam. Biomass offers many strategic benefits, including that biofuels can fit into the existing oil based infrastructure nearly seamlessly. Other resources such as WTE, LFG, and methane from wastewater treatment plants can be used to produce baseload power and are not subject to intermittent outages as are wind and solar.

One of the next steps would be to conduct a comprehensive biomass resource assessment and analysis of opportunities. The assessment could be performed all at one time by a single entity, or the work could be split up amongst a team of researchers. Several activities would lend themselves to being performed by students and staff from the University of Guam.

Major next steps for each of the biomass sub-technologies are described below. Detailed budget estimates would need to be prepared for each category. The cost would be dependent on level of detail required.

1. WTE is a small but important part of any strategic effort to develop renewable resources on Guam. The cost to further evaluate WTE could range from $\$ 25,000$ for a pre-feasibility evaluation, to $\$ 300,000+$ for a detailed waste characterization and investment grade economic and technical analysis of WTE options.

- Work with the Receiver and the SWMD to obtain any additional waste composition analysis data. The 1980 study referenced herein is old, and the 2010 waste sorts are being conducted on such a small number of samples that it is not statistically valid data. The 2010 sorts are also being performed only on the residential sector, so waste from other sectors (e.g. commercial, government, industrial, etc) is not being counted.

- Evaluate other potential sources of feedstock for a WTE plant including tires, corrugated cardboard, and green matter, which are no longer allowed to be dumped in Ordot.

- Explore the development of new regulations on WTE. This is an action that the Energy Task Force could undertake or establish a sub-committee to explore. Clearly, existing laws and legal challenges by GRRP need to be included in this analysis. The need for minimum flows and tip fees of materials going to the new landfill also need to be considered.

- One potential arrangement for a WTE facility would be to locate a plant "behind the fence" of the new landfill. In this manner, tip fees could be paid at the gate which could be used for landfill bond repayment. Rather than burying the material directly in the landfill, it could be directed to a WTE plant to produce and sell energy. The residual ash and non-combustibles could then be recycled and/or sent to the landfill. Production of energy would extract additional value from Guam's solid waste and prolong the life of the new landfill by reducing the amount of material that gets buried. A detailed cost benefit analysis of this option would 
need to be undertaken. The cost of this analysis is not included in the cost estimate projected above.

- Evaluate local recycling efforts, markets, and options and determine potential impacts on the waste stream and the economics of WTE.

- GPA should consider developing a separate WTE RFP once legal and regulatory issues have been resolved.

2. The production of, or use of biodiesel or vegetable oil warrants further investigation. The state of Hawaii is using both locally produced and imported biofuels to help meet its renewable energy targets. The cost impact of this analysis is estimated to be $\$ 25,000$ $\$ 50,000$, excluding the costs of a direct test in GPA's engines. The cost for that would need to be ascertained based on HECO's experiences.

- Conduct a survey of waste grease supplies on Guam. Determine who produces the material, how it is collected and disposed, what the costs are, and whether there are any opportunities for a local business to manufacture biodiesel locally.

o Determine the expected costs of procuring biodiesel from the mainland or Asia.

- Gather case study data associated with the use of biofuels or vegetable oil in diesel systems in Hawaii, other islands, or other communities.

- Determine equipment modifications needed to use biodiesel or vegetable oils in the GPA system. Based on other case studies or work done in Hawaii, it would be useful for GPA to conduct a test of biofuel use within its system. This would be a comprehensive assessment that evaluates costs, impacts on heat rates and performance, fuel storage and handling, air emissions, and overall feasibility.

- Estimate the levelized cost of energy produced from biodiesel in various blends of biodiesel/petroleum diesel percentages.

- Prepare a report and briefing for GPA and the Energy Task Force to communicate results of the detailed assessment.

3. Based on the previously-mentioned study by Duenas Associates and URS, the production of energy from LFG from Ordot does not appear to be very promising. Estimated cost of these activities is less than $\$ 5,000$.

- Gather additional data on the potential for Ordot to produce and capture landfill gas post closure, as appropriate. This could be accomplished through a brief meeting with the Receiver and SWMD.

- Meet with Naval Facilities Engineering Command (NAVFAC) to discuss DOD landfills, and whether they have any plans for assessing methane potential at onbase landfills.

○ Monitor GPA RFPs for any possible LFG bids.

4. The additional cost of the analysis of this option would be $\$ 25,000$ for a preliminary assessment to $\$ 100,000$ for a detailed feasibility study.

- Determine who has responsibility for the design of wastewater treatment plants associated with the military build-up. Meet with the responsible parties to discuss present construction plans and proposed wastewater treatment technologies. Identify whether it is possible to evaluate the economic and technical feasibility of adding anaerobic digestion to the wastewater treatment plants prior to final system design and capitalization. 
5. While there may be challenges to growing dedicated biomass for energy, it still makes sense to explore this option further. The following steps are recommended. The cost to perform this analysis is estimated at $\$ 25,000$ to $\$ 50,000$.

- Using geographical information systems, filter out all steep lands and developed areas to identify areas that are simply not suitable for biomass feedstock production.

- Overlay land use and vegetation maps to determine current usage of the land base.

- Evaluate land ownership of large contiguous parcels. The objective would be to identify potential lands suitable for growth of biomass feedstocks. DOD is likely to have the land - whether it is available for purposes of biofuel production would need to be determined.

- Estimate the acreage available as well as potential yields of various species.

- Evaluate technical and economic feasibility of producing biofuels or solid feedstocks. 


\section{Summary of Recommendations and Conclusions}

The site visit and subsequent research on Guam's energy efficiency and renewable energy opportunities is a basic, preliminary overview to provide the Energy Task Force with a set of next steps. The areas of opportunity that have been identified are based on this preliminary review. Further investigation or consultation may be required before undertaking any next steps. The key opportunities, potential steps for policy, and concluding points are summarized in this section.

\subsection{Key Opportunities}

Examples of energy efficiency and renewable energy opportunities to include in strategic planning or for further consideration are summarized below.

\section{General}

- Based on existing overall baseline energy use, develop specific goals to reduce overall fossil fuel consumption.

- Develop a Strategic Energy Plan and Implementation Strategy to implement near-term opportunities identified in this report, and to develop approaches for further feasibility analysis for identification and implementation of longer-term opportunities.

- Policies, programs, regulations, and codes/standards should be reviewed for energy efficiency and renewable energy targets. High standards should be set to push the industry in the direction of reducing overall fossil fuel consumption.

- Conduct a transportation assessment to determine energy useage, analyze options, and identify reduction and renewable strategies.

\section{Energy Efficiency}

- Work with technical experts to design educational materials for Guam to address specific information and outreach needs. Flyers, posters, and stickers can be designed that could be distributed among the appropriate building sectors.

- Develop training courses and materials for both architects and workers in the construction sector to improve energy awareness. Energy efficiency in retrofit, renovation, and new construction can be included in terms of design, materials, and equipment.

- Create guidebooks and self-assessment checklists. These guidebooks could be designed as standalone products for specific sectors or integrated into the training courses described above.

- Create a cool-roof program by identifying potential buildings that can be used as pilot projects.

- Continue existing energy audits with private companies and utilize the results to benefit the entire building portfolio.

\section{Renewable Energy}

- Conduct and analyze results from wind anemometry studies to capture wind potential.

- The Energy Task Force should continue to work with GPA to identify potential sites for solar PV installation.

- Develop solar thermal strategies for residential, commercial, and governmental buildings

- DOD and GPA should continue to work cooperatively on the drilling of geothermal temperature gradient holes.

- Consideration should be given to all alternative fuel potential in the form of WTE, LFG, biofuels, and biomass crops. 


\subsection{Conclusion}

There are many opportunities found in Guam for the adoption of energy efficiency and renewable energy technologies, and development and implementation of energy policy, standards, and codes that has been outlined in this report.

Due to fluctuating energy prices, including the record high price for oil in 2008, and the imminent military build-up, Guam has focused attention on the need to develop alternatives to its near 100\% reliance on fossil fuels. Guam is in a unique position to undertake a concerted effort to address current energy and environmental challenges. Due to its geographic isolation, non-renewable resources are extremely limited and subject to large volatility in pricing and availability. Energy security is fundamental to Guam's economic future and sustainability. Consequently, creating a stable investment atmosphere remains challenging, while the quality of life for residents and visitors continues to be affected. However, the unique position of Guam also offers many natural advantages. The island is endowed with diverse sources of alternative energy.

With NREL's assistance, an Energy Task Force has been established and the following mission and vision of the have been adopted:

\section{Vision}

Create a sustainable future for Guam by reducing dependence on fossil fuels.

\section{Mission}

Unite the citizenry through the vision and enhance the well-being of Guam's population, ensure national and economic security through energy independence and diversification, improve the local environmental quality, decrease Guam's vulnerability as a small island state, and further the development of the territory by developing a comprehensive energy plan that will embrace energy efficiency and conservation.

In conclusion, a strong energy plan surveys and assesses need and provides analysis and recommendations for appropriate technologies and programs relevant to its environment while addressing economic viability. It addresses a full range of energy options, with a focus on energy efficiency and renewable energy technologies and lays out a road map for socioeconomic development.

Plans to develop an implementation plan are next steps once an energy strategic plan has been completed. A plan is only part of the solution - it lays the groundwork. Action strategies will develop the roadways in which these vehicles can drive energy efficiency and renewable energy market adoption and deployment. 


\section{A. Utility Baseline Information}

\section{A.1 Generation}

GPA must meet or exceed the following generation performance standards:

- $90 \%$ or greater of generation to come from base load plants

- $10 \%$ or less of generation to come from Combustion Turbine (CT)/Diesel generation.

Table 10 lists the base load generation. Table 11 is a list of the Independent Power Producers. Table 12 is a list of the total generation resources (traditional fuels) on the island and Figure 24 shows the installed capacity over time.

Table 10. GPA Baseload Generation

Equivalent Availability Factor Performance Factors

\begin{tabular}{lrrrrrrr}
\multicolumn{1}{c}{ Generation Unit } & $\mathbf{2 0 0 3}$ & $\mathbf{2 0 0 4}$ & $\mathbf{2 0 0 5}$ & $\mathbf{2 0 0 6}$ & $\mathbf{2 0 0 7}$ & $\mathbf{2 0 0 8}$ & $\mathbf{2 0 0 9}$ \\
\hline Cabras Unit \#1 & $\mathbf{7 8 . 1 \%}$ & $65.0 \%$ & $75.0 \%$ & $82.5 \%$ & $85.0 \%$ & $85.0 \%$ & $87.0 \%$ \\
Cabras Unit \#2 & $63.4 \%$ & $94.0 \%$ & $75.0 \%$ & $82.5 \%$ & $85.0 \%$ & $85.0 \%$ & $87.0 \%$ \\
Tanguisson Unit \#1 & $96.4 \%$ & $89.0 \%$ & $85.0 \%$ & $87.0 \%$ & $87.0 \%$ & $87.0 \%$ & $87.0 \%$ \\
Tanguisson Unit \#2 & $80.7 \%$ & $42.0 \%$ & $85.0 \%$ & $87.0 \%$ & $87.0 \%$ & $87.0 \%$ & $87.0 \%$ \\
Cabras Unit \#3 & $0.0 \%$ & $56.0 \%$ & $62.0 \%$ & $76.0 \%$ & $90.0 \%$ & $90.0 \%$ & $90.0 \%$ \\
Cabras Unit \#4 & $65.5 \%$ & $67.0 \%$ & $62.0 \%$ & $76.0 \%$ & $90.0 \%$ & $90.0 \%$ & $90.0 \%$ \\
MEC Unit \#8 & $83.4 \%$ & $95.0 \%$ & $90.0 \%$ & $90.0 \%$ & $90.0 \%$ & $90.0 \%$ & $90.0 \%$ \\
MEC Unit \#9 & $87.0 \%$ & $96.0 \%$ & $90.0 \%$ & $90.0 \%$ & $90.0 \%$ & $90.0 \%$ & $90.0 \%$ \\
Average Unit EAF Targets & $69.3 \%$ & $75.6 \%$ & $78.0 \%$ & $83.9 \%$ & $88.0 \%$ & $88.0 \%$ & $88.5 \%$ \\
& & & & & & & \\
Weighted Average EAF Targets & & $77.4 \%$ & $77.4 \%$ & $83.6 \%$ & $87.7 \%$ & $87.7 \%$ & $88.4 \%$
\end{tabular}

Table 11. Independent Power Producers

\begin{tabular}{|l|l|l|l|l|}
\hline Plant & IPP & Plant Capacity (MW) & $\begin{array}{l}\text { Contract Effective } \\
\text { Date }\end{array}$ & $\begin{array}{l}\text { Contract } \\
\text { Termination Date }\end{array}$ \\
\hline $\begin{array}{l}\text { Piti Unit 7 } \\
\text { (Combustion } \\
\text { Turbine) }\end{array}$ & TEMES & 40 & December 1997 & December 2017 \\
\hline $\begin{array}{l}\text { Piti Unit 8\&9 (Slow } \\
\text { Speed Diesel) }\end{array}$ & MEC & 88 & January 1999 & January 2019 \\
\hline $\begin{array}{l}\text { Tanguisson Unit 1\&2 } \\
\text { (Steam) }\end{array}$ & Pruvient & 53 & August 1997 & August 2017 \\
\hline
\end{tabular}


Table 12. GPA Generation Resources

\begin{tabular}{llrrr}
\hline \multicolumn{1}{c}{ Unit } & \multicolumn{1}{c}{ Technology } & Fuel & Capacity, MW & Service Date \\
\hline Cabras 1 & Steam Turbine (ST) & RFO No. 6 & 66 & 1974 \\
Cabras 2 & ST & RFO No. 6 & 66 & 1975 \\
Cabras 3 & Slow Speed Diesel (SSD) & RFO No. 6 & 40 & 1996 \\
Cabras 4 & SSD & RFO No. 6 & 40 & 1996 \\
Piti 8 (MEC) & SSD & RFO No. 6 & 44 & 1999 \\
Piti 9 (MEC) & SSD & RFO No. 6 & 44 & 1999 \\
Tanguisson 1 (PRU) & ST & RFO No.6 & 26.5 & 1976 \\
Tanguisson 2 (PRU) & ST & RFO No.6 & 26.5 & 1976 \\
Dededo CT 1 & Combustion Turbine (CT) & Diesel No. 2 & 23 & 1992 \\
Dededo CT 2 & CT & Diesel No. 2 & 23 & 1994 \\
Machche CT & CT & Diesel No. 2 & 21 & 1993 \\
Marbo CT & CT & Diesel No. 2 & 16 & 1993 \\
Yigo CT & CT & Diesel No. 2 & 21 & 1993 \\
Piti 7 (TEM) & CT & Diesel No. 2 & 40 & 1997 \\
Dededo Diesel 1-4 & Medium Speed Diesel (MSD) & Diesel No. 2 & 2.5 ea/10 total & 1972 \\
Talofofo Diesel 1 and 2 & MSD & Diesel No. 2 & 5 ea/10 total & 1994 \\
Paluntat Diesel 1 and 2 & MSD & Diesel No. 2 & 4.4 ea/8.8 total & 1993 \\
Tenjo Diesel 1-6 & MSD & Diesel No. 2 & 4.4 ea/26.4 total & 1994 \\
\hline
\end{tabular}

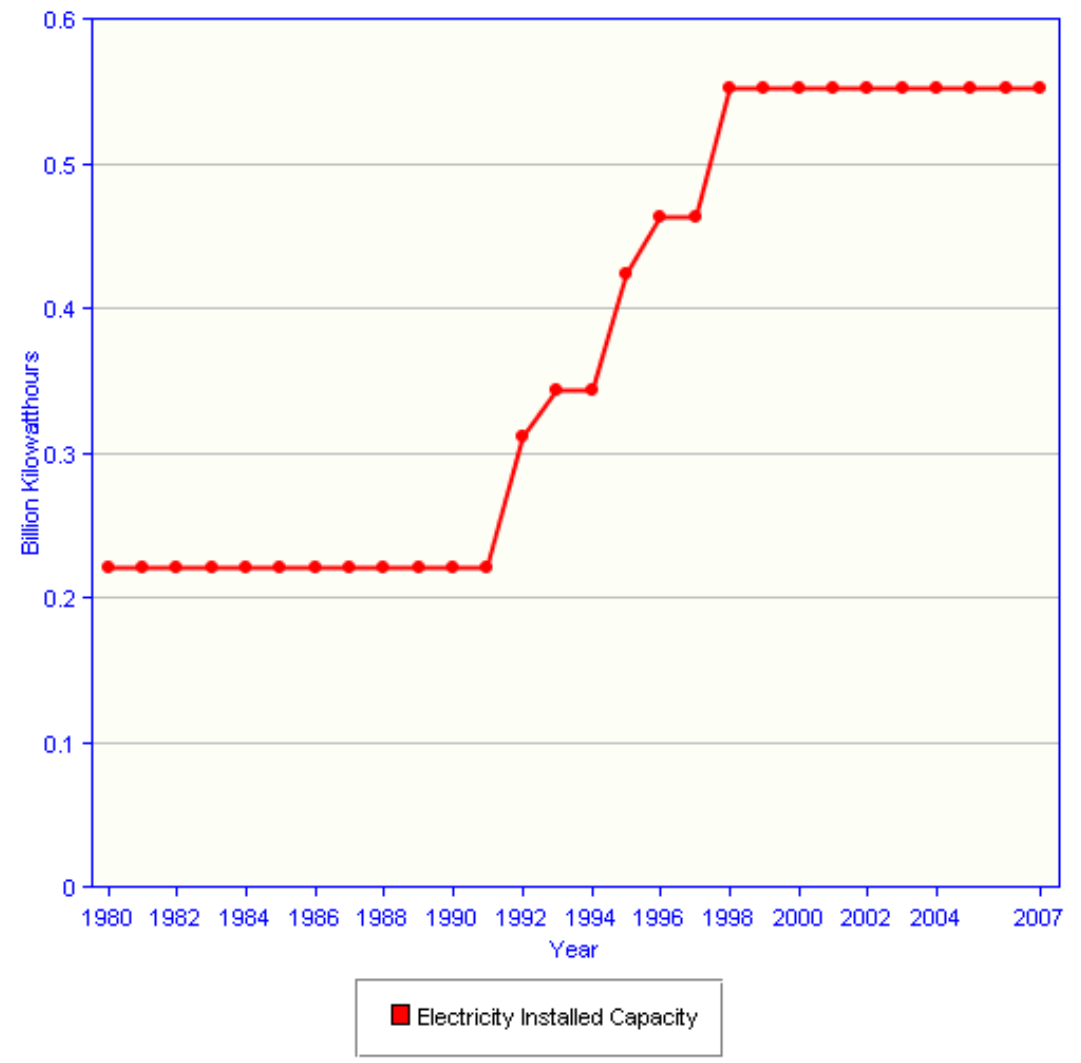

Figure 24. GPA installed capacity (in billions of kW) ${ }^{59}$ Source: EIA

${ }^{59}$ EIA Guam Energy Profile. 
In 1995 and 1996, GPA commissioned Cabras \#3 and \#4. These units use a slow-speed diesel technology and were the largest units available in this class. This technology converted fuel into electrical energy using about a $25 \%$ to $30 \%$ less fuel than Cabras \#1 \& \#2. The newly commissioned Cabras units \#3 and \#4 experienced high forced outage rates over the next two years. However, by 1997 GPA had reduced loss-of-load outage durations due to lack of generation from over 600 hours each in FYs 1995 and 1996 to about an hour.

The Cabras plant includes two $66 \mathrm{MW}$ steam turbine generator units (\#1 and \#2), and two $40 \mathrm{MW}$ slow speed (102.9 RPM) diesel engine generator units. All generator sets operate in base load service. The steam turbines are General Electric (GE) $66 \mathrm{MW}, 3,600$ RPM with GE 77,647 kVA, 0.85 pf, 13,800 volts, 3,249 amps generators, and the diesel generators are ABB, SA, type W.950/95/70, 49,280 kVA, $0.8 \mathrm{pf}, 102.9 \mathrm{RPM}, 13.8 \mathrm{kV}, 2062$ amps, 3 phase wye, 70 poles; air cooled. . Seawater is used as the cooling medium in the main condensers of Cabras units \#1 and \#2. It is also the jacket (engine) cooling medium for Cabras Units \#3 and \#4. All 4 generators produce electricity at 13,800 volts. The voltage is then stepped up to 115,000 volts $(115 \mathrm{kV})$ in the main transformers $(2 \mathrm{x} 80 \mathrm{MVA}$ for \#1 and \#2, and $2 \mathrm{x}$ 50 MVA for \#3 and \#4) for transmission and distribution.

The Tanguisson plant consists of two $26 \mathrm{MW}$ steam turbine generator units. Both units are operated in base load service. The turbines are GE 26,500 kW, 3,600 RPM. The generators are GE 29,412 KVA, 0.90 pf, 13,800 volts, 1,179 amps.

The Dededo combustion turbine plant consists of two GE Frame 5 machines. CT \#1 (CT1) is a Model MS 5001 PA (advanced version) rated at 23 MW. CT \#2 (CT2) is a Model MS $5001 \mathrm{P}$ (standard version) rated at $22 \mathrm{MW}$. The units are used for peaking and emergency operations. The combustion turbines are rated 5,100 RPM (turbine), 25,000 kW. The generators are GEC Ahlstom; 26,200 kVA; $3600 \mathrm{RPM} ; 13.8 \mathrm{kV}$. Their rated outputs are $23 \mathrm{MW}$ (CT1), and $22 \mathrm{MW}$ (CT2). The generators produce electricity at 13,800 volts. The voltage is stepped up to 34,500 volts $(34.5 \mathrm{kV})$ in the main transformers (30 MVA maximum rating) for transmission and distribution.

The Dededo diesel plant consists of four General Motors (GM) Electro-Motive Diesel (EMD) diesel engine generators. Each diesel generator is rated at 2.5 MW. The plant's total generating capacity is 10 MW. The units are used for peaking and emergency service. The diesel engines operate at 900 RPM. The generators are GM-EMD; Model A20-C1; 3,250 kVA, 0.8 pf, rated output $2.5 \mathrm{MW}, 4,160$ volts, air cooled. The engines can operate with just one fan in operation at a slightly reduced load (2.2 MW). The generator voltage is stepped up to $24 \mathrm{kV}$ for transmission and distribution.

The Macheche and Yigo combustion-turbine plants each consist of one GE LM2500 CT generator unit. Each unit is rated at $22 \mathrm{MW}$. These units are used for peaking and emergency operations. The combustion turbines are 3,600 RPM, 25,000 kW. The generators are Brush Electric Model BDX7-167E, $3 \mathrm{~m} 600 \mathrm{RPM}, 13,800$ volts, 25,000 kW, type HC/OP/OPLTR, class OA/FA/FA, 18/24/30 MVA, 13.8 $.90 \mathrm{pf}$, air cooled (rated output $22 \mathrm{MW}$ ). The generator voltage is stepped up to $34.5 \mathrm{kV}$ for transmission and distribution.

The Manenggon plant consists of two Wartsila-ABB diesel engine generators. Each diesel generator is rated at $5 \mathrm{MW}$. The plant's total generating capacity is $10 \mathrm{MW}$. The units are used for peaking and emergency service. The diesel engines are 5,522 kW, 720 RPM. The generators are ABB Stromberg; type HSG $900 \mathrm{LS} 10 ; 7,250 \mathrm{kVA} ; 13.8 \mathrm{kV} ; 303 \mathrm{amps}$; air cooled. The generator voltage is stepped up to $34.5 \mathrm{kV}$ for transmission and distribution. 
The Marbo plant consists of one Fiat TG 16 CT generator unit. This unit is rated at $16 \mathrm{MW}$ and is used for peaking and emergency operations. The CT operates at 4,914 RPM. The generator operates at 1,800 RPM, 19,000 kVA, $13.8 \mathrm{kV}, 794.9$ amps, $0.8 \mathrm{pf}$, air cooled. The generator voltage is stepped up to 34.5 $\mathrm{kV}$ for transmission and distribution.

The Tenjo plant consists of six Caterpillar-Kato diesel engine generators (two units are currently being overhauled). Each unit is rated at $4.88 \mathrm{MW}$ each. The units are used for peaking and emergency service. The diesel engines are Caterpillar; Model 3616, 6,095 HP, 16 cylinder, V-type, turbocharged, 900 RPM, \#2 fuel (diesel) oil. The generators are Kato: Model A256730000, 4,880 kW, 6,100 kVA, 0.8 pf, 13.8 $\mathrm{kV}, 255 \mathrm{amps}$, air cooled. The generator voltage is stepped up to $34.5 \mathrm{kV}$ for transmission and distribution.

A major project aimed at reducing forced power outages was completed after two years. The project focused on automating generation controls, which allows for other generators to increase power output in the event one of the larger base load units trips and is forced offline. These forced outages caused power outages in many areas while reserve generators were being brought online to restore power. The upgrade enables standby generators to quickly make up for the loss of generation through automation instead of coordinating a restoration of power through the slower manual processes.

GPA increased the number of Fast Track generating units online. Work at three $20 \mathrm{MW}$ combustion turbine units (Dededo CT No. 2, Macheche, and Yigo CT) resulted in an additional $60 \mathrm{MW}$ of reserve that can be brought online to support maintenance, overhauls, or emergency shutdowns at other GPA base load generating units.

The Fast Track units represent one part of the generating mix that is used to provide recovery and support during typhoon restorations and blackouts. Bringing these units online adds operational flexibility during hours of peak demand today and anticipated additional load from the pending military buildup tomorrow.

The Fast Track units are a component in the project that connects large load centers to major substations via underground transmission lines. The Dededo CT Plant is connected to Andersen Air Force Base via an underground transmission line, the Yigo CT is within close range of Andersen Air Force Base, and the Macheche CT is connected to the Guam International Airport Authority.

Figure 23 in Section 3.3.2 of the report shows a map of the island's transmission system as well as potential locations for solar and wind systems. This indicates where GPA could collaborate with PV and wind installers to tie into the existing electric grid.

\section{A.2 GPA System Improvements in FY 2009}

\section{A.2.1 Major Transmission Lines Secured Underground}

Electricity is delivered through a transmission and distribution grid consisting of a combination of 115 $\mathrm{kV}, 34.5 \mathrm{kV}$, and $13.8 \mathrm{kV}$ lines. GPA energized the final portion of the massive project to move main transmission lines underground (as shown in Figure 25), where they are shielded from typhoons and other disasters and contribute to timely recovery of power and other services for the entire island). Funded by a grant from the Federal Emergency Management Agency, the project cost \$25 million and took four years to complete.

The final leg of the project was completion of the Harmon to Macheche underground transmission line, which provides a secure, direct line from the Macheche Power Plant to the Guam International Airport Authority. Since 2005, GPA placed major transmission lines underground that serve the Guam Memorial Hospital and central areas of Harmon, Tamuning, and Tumon. 
GPA also buried a significant portion of line connecting the Tanguission Power Plant to the Harmon Substation. The Tanguission Power Plant is capable of producing over $50 \mathrm{MW}$ - this number added to the $20 \mathrm{MW}$ from Macheche Power Plant means that GPA can potentially transmit $70 \mathrm{MW}$ of uninterrupted power during tropical storms or typhoons via the underground network.

Avoiding repairs on the underground lines is a savings to rate payers that protects revenue and restores island power to residences and businesses after a major storm. The hospital and airport will have the potential for uninterrupted power during tropical storms and typhoons. In addition, GPA's restoration crews will be able to work on restoring service to neighborhood homes, schools, and businesses if lines to major substations, the hospital, airport, and businesses and hotels along Tumon Bay are sheltered from storm damage.

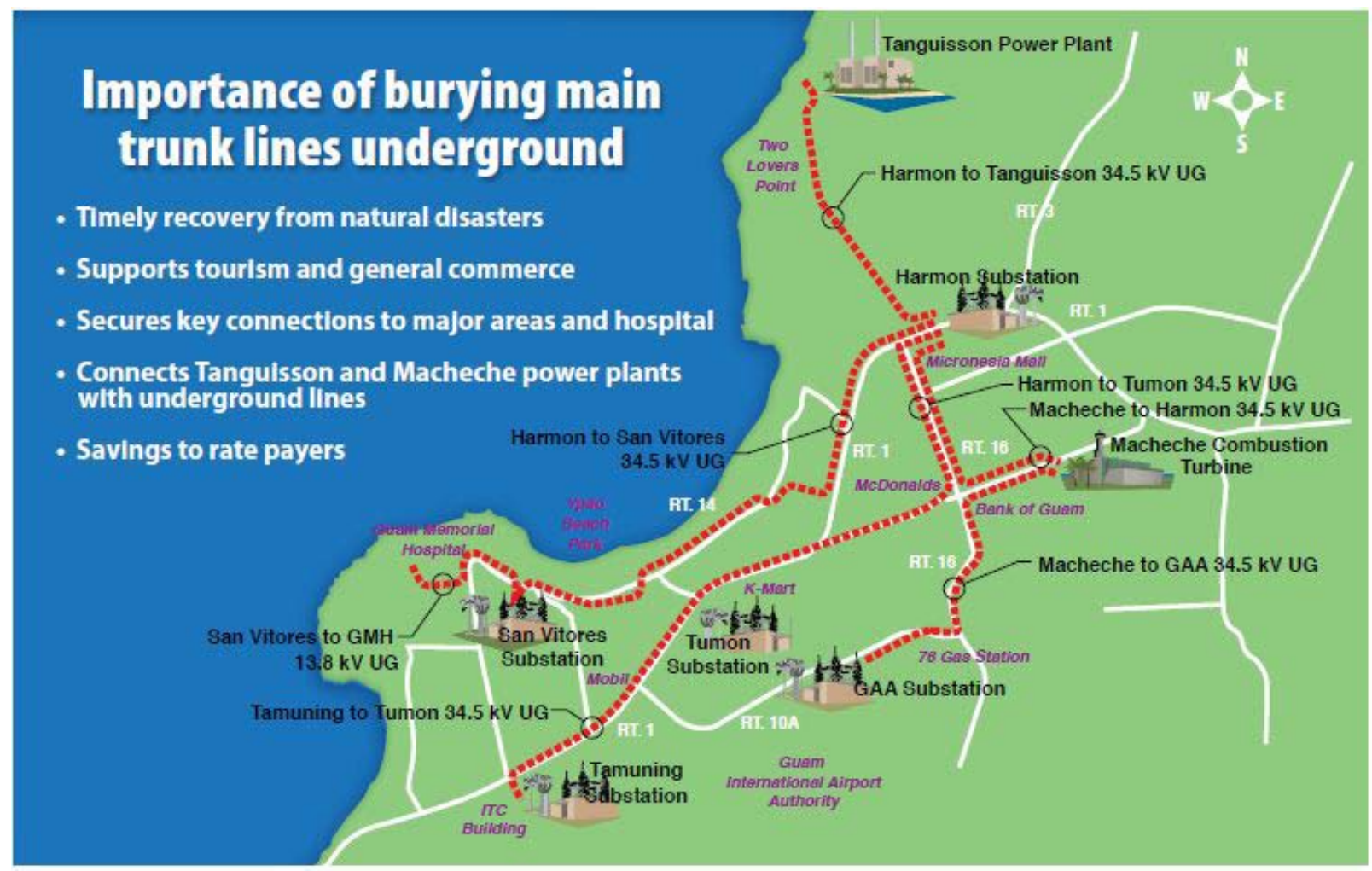

Figure 25. GPA buried transmission lines Source: GPA

\section{A.2.2 Net Metering}

The first use of "net metering" was implemented at a residence in Barrigada in 2009. Net metering allows the GPA customer to offset power consumption by generating renewable energy, such as solar power. The renewable power incentive program was made possible by passage of PL 27-132 and adoption by the PUC. The legislation was intended to encourage the use of new power generation technologies to defer the need for additional capital investment by GPA.

\section{A.2.3 Groundwork Laid for Pre-Paid Meters}

The cost of residential electricity is about $\$ 0.23 / \mathrm{kWh}$, where $\$ 0.15$ is the cost of fuel and $\$ 0.08$ is for infrastructure. A pilot project to determine the feasibility of pre-paid meters for residential customers was launched in 2009. One hundred households - primarily those of GPA employees - volunteered to participate in the project, which is spearheaded by the GPA Engineering Department. The technology used in the project has features that easily interface with GPA's existing computer systems. 
In the future, pre-paid meters will allow residential customers to manage their electric utility accounts. Families will be able to manage their accounts by monitoring consumption and conservation of electricity. Instead of monthly bills and security deposits, customers will be able to choose the payment schedule that is best suited for their personal needs. If the pilot project is successful, GPA will offer prepaid meters to more residential customers.

\section{A.2.4 Declining Sales}

GPA's sales have been trending downward for the last few years as is shown in Figure 26. While the number of customers is growing, the average usage is declining as a result of conservation efforts by many of GPA's customers. These conservation measures are the result of the steep increases in the fuel portion of the bill for the last few years. GPA expects to see positive growth for FY 2011 as conservation measures become fully realized, the impacts of the military buildup begin to show, and the economy begins to recover from the impact of the world-wide economic crisis.

\section{Sales Activity (kWh)}



Figure 26. Decline of GPA sales Source: GPA

\section{A.3 Utility Energy Efficiency}

GPA staff came up with PMCs to improve base load plant reliability and efficiency. GPA staff recognized that GPA did not have sufficient plant management, technical, and plant operation acumen at GPA to run its base load facilities well. Keeping many of these skill sets full-time at GPA is economically prohibitive.

Additionally, GPA already had difficulty recruiting to fill technical and professional positions. Also, the Government of Guam's procurement practices do not support an operations environment well as procurement issues often result in prolonged unit outages. Furthermore, GPA recognized the need for better, consistent training of its plant staff. Finally, staff foresaw that performance-based compensation would best drive exemplary performance and better protect the ratepayer from poor performance.

Peaking unit technologies are relatively inexpensive and quick to install but expensive to operate. Therefore they are ideally operated only during system peak demand periods or as reserve units in the 
absence of reliable base load capacity. Efficient base load units require much longer permitting and construction lead times. However, they possess much higher capital requirements for installation but are less expensive to operate. Intermediate units have unit characteristics between peaking and base load.

Guam's year-round tropical climate and tourism-based economy results in a relatively flat load cycle with high load factor. Such characteristics tend to favor base load technology additions since operation near the peak is the norm (flat load profile). As an example, Figure 27 shows the GPA average demand hourly load shape for the period April 29-30, 2008. Note that GPA requires peaking capacity for only four hours for about $15 \mathrm{MW}$ to $19 \mathrm{MW}$ incremental peak.

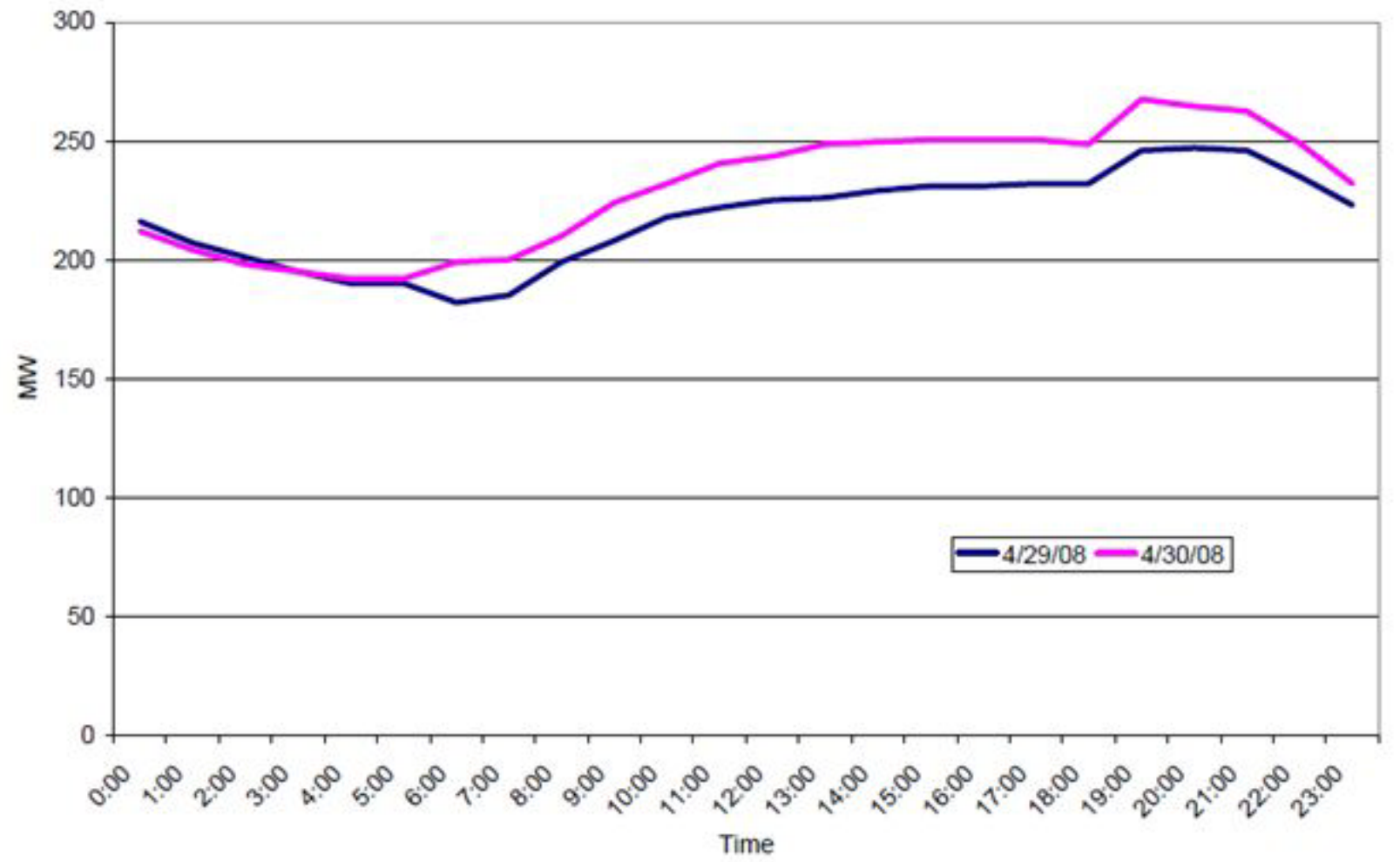

Figure 27. GPA average hourly generation requirements Source: GPA

Regarding the distribution system, savings would be realized by improving technical efficiency (improved connections, reducing line resistance, correctly sizing transformers to their loads, etc.) as well as improving nontechnical efficiency (inaccurate billing, meters not being calibrated, etc.). 


\section{B. Energy Efficiency Baseline}

Sectors of energy consumption are categorized by the Secretariat of the Pacific Community and GPA as commercial and government, residential, U.S. Navy, and street and outdoor lighting.

Within the commercial and government sectors we can include the hospitality industry, medical, government, commercial, and higher education. The construction of buildings on Guam is consistent with tropical island building code, which emphasizes construction methods to withstand typhoons typical of the area. From observations, the majority of commercial and residential buildings are reinforced concrete buildings with high air conditioning loads. The heat and humidity levels dictate the use of air conditioning on island. Some buildings are constructed of concrete or wood with tin roofs, but seem to be mostly residential. These buildings are not preferred due to their lack of withstanding typhoon conditions. Glazing is either single or double-glazed with external typhoon shutters attached to the building to be closed during inclement weather.

\section{B.1 Current Status}

The Guam Energy Office has identified measures to improve energy efficiency on the island; Recovery Act funding was requested to implement many of these tasks. Certain activities were entered into memorandums of understanding or RFPs, including the following:

- Improve municipal lighting

- Replace old metal halide and high pressure sodium light bulbs along highway and major suburban roadways with energy-saving Light Emitting Diode (LED) lights

- Retrofit public facilities

- Energy audits performed by energy services companies at public facilities, such as schools, housing, and community centers to identify potential retrofits. Facilities will be retrofitted based on audits.

- Financial incentives for building improvements

- Rebates for residents, non-profit organizations, and businesses for energy efficiency measures, including solar hot water heating, lighting, insulation, air conditioning, and windows.

- Resource conservation manager program

○ Reduce government expenditures for energy, water, fuel oil, solid waste disposal, and other utilities by improving energy use practices, auditing utility billing and services, and installation of resource management equipment.

- Residential energy performance score

- Home energy audits to identify opportunities for efficiency improvements and encourage voluntary retrofits by providing information to the real estate market. Members of Guam Contractors Association, building code inspectors, and GPA staff will be trained to deliver the audits.

- Community education and outreach

- Guam Department of Education will work with island schools and other organizations to increase energy awareness and promote future conservation of resources. Also, education curriculum and courses in Energy Technician Training and Building Code compliance will be developed.

- Sustainable Development Forward 
- Energy saving guidance for households, database to evaluate savings estimates for residential and commercial facilities, and adoption of state-of-the-art building energy codes that will increase energy efficiency in new buildings by $30 \%$ or more.

Recovery Act funding was requested and granted for the state energy program, weatherization assistance program, energy efficiency conservation block grants, and the energy efficiency appliance rebate program. This funding assists with implementing a few of the measures outlined by the Energy Office, however does not provide funding for all measures identified. A summary of the program and the funding allocation for each area is summarized in Figure $28^{60}$.

\begin{tabular}{|c|c|c|c|c|}
\hline Program & $\begin{array}{l}\text { State Energy } \\
\text { Program }\end{array}$ & $\begin{array}{l}\text { Weatherization Assistance } \\
\text { Program }\end{array}$ & $\begin{array}{l}\text { Energy Efficiency } \\
\text { Conservation Block Grants }\end{array}$ & $\begin{array}{l}\text { Energy Efficiency Appliance } \\
\text { Rebate Program }\end{array}$ \\
\hline \multirow[t]{2}{*}{$\begin{array}{l}\text { Award } \\
\text { (in millions) }\end{array}$} & $\$ 19.1$ & $\$ 1.1$ & $\$ 9.6$ & $\$ 0.2$ \\
\hline & $\begin{array}{l}\text { The Guam Energy } \\
\text { Office has been } \\
\text { granted } \$ 19.1 \text { million } \\
\text { in State Energy } \\
\text { Program funds to } \\
\text { invest in territory- } \\
\text { level energy efficiency } \\
\text { and renewable } \\
\text { energy priorities. }\end{array}$ & $\begin{array}{l}\text { The Guam Energy Office has been } \\
\text { granted } \$ 1.1 \text { million in } \\
\text { Weatherization Assistance } \\
\text { Program funds to scale-up } \\
\text { existing weatherization efforts } \\
\text { on the island, creating jobs, } \\
\text { reducing carbon emissions, and } \\
\text { saving money for Guam's low- } \\
\text { income families. Over the course } \\
\text { of the Recovery Act, Guam } \\
\text { expects to weatherize more than } \\
\text { 2oo homes. The program also } \\
\text { includes workforce training and } \\
\text { education as part of the island's } \\
\text { efforts to develop a green } \\
\text { workforce. }\end{array}$ & $\begin{array}{l}\text { Guam has been granted } \\
\$ 9.6 \text { million for Energy } \\
\text { Efficiency and } \\
\text { Conservation Block } \\
\text { Grants (EECBC) to } \\
\text { develop, promote, } \\
\text { implement, and manage } \\
\text { local energy efficiency } \\
\text { programs. }\end{array}$ & $\begin{array}{l}\text { The Guam Department of } \\
\text { Administration has been } \\
\text { granted } \$ 166,000 \text { for the } \\
\text { Energy Efficient Appliance } \\
\text { Rebate Program, which } \\
\text { offers consumer rebates } \\
\text { for purchasing certain } \\
\text { ENERGY STAR } @ \text { appliances. } \\
\text { These energy efficient } \\
\text { appliances reduce energy } \\
\text { use and save money for } \\
\text { families, while helping the } \\
\text { environment and } \\
\text { supporting the local } \\
\text { economy. }\end{array}$ \\
\hline \multicolumn{5}{|c|}{$\begin{array}{l}\text { Figure 28. Recovery Act funding allocated to energy efficiency measures on Guam (in millions of } \\
\text { U.S. dollars) } \\
\text { Source: DOE }\end{array}$} \\
\hline
\end{tabular}

While the Energy Office has determined areas of focus and has been granted funding to implement specific measures the work has only just begun and there are gaps in the level of coverage on-island. NREL's goal in assessing the current level of energy efficiency is not intended to provide duplication of efforts, but rather to assist the island in identifying areas that have not been noted previously for energy conservation measures.

\section{B.2 Initial Observations by Sector}

\section{B.2.1 Commercial and Government}

Of all sectors on-island the commercial and government buildings seemed to have the most comprehensive implementation plan. During the island site visit, investment grade energy audits were being conducted at the airport and five hotels, new construction at Guam Community College was being built to achieve LEED certification, and community offices at Dededo were undertaking low-cost measures toward energy reduction. NREL staff were not able to visit any medical buildings to observe current practices, however this may be an area to explore further with investment-grade audits.

\footnotetext{
${ }^{60}$ DOE Recovery Act State Memo, Guam (June 1, 2010):

http://www.energy.gov/recovery/documents/Recovery_Act_Memo_Guam.pdf.
} 
In general, observations and interviews within the commercial and government sector indicated an overall need for energy awareness. Simple, low-cost measures could be implemented to increase energy efficiency and conservation on island. Examples of this include temperature settings on air conditioning units/systems and better lighting controls.

\section{B.2.1.1 Temperature}

The Dededo Senior Center is a good example of temperature control within a community building, and simple improvements could be made. The thermostat was set to $65^{\circ} \mathrm{F}$ on a forced air system with ceiling vents. The temperature at ceiling level was $2^{\circ} \mathrm{F}$ cooler than at floor level, indicating striation. The air conditioning was turned on, windows were open in the bathrooms, and gaps between the glass doors allowed cool air to leak out of the building as shown in Table 13.

Table 13. Dededo Senior Center Indoor Temperature and Related Costs

\begin{tabular}{|l|l|}
\hline Dededo Senior Center & $8 \mathrm{am}-8 \mathrm{pm}$ \\
\hline Hours of Operation & $28 \mathrm{\complement} / \mathrm{kWh}$ \\
\hline Cost/kWh & $1400-1700 \mathrm{kWh} /$ month \\
\hline Monthly Consumption & $65^{\circ} \mathrm{F}$ \\
\hline Thermostat setting & $\begin{array}{l}2^{\circ} \mathrm{F} \text { between floor and } \\
\text { ceiling }\end{array}$ \\
\hline Temperature gradient &
\end{tabular}

Low-cost measures that could be implemented at the Dededo Senior Center include the following:

- Add vent guards to the ceiling vents to direct air downward to cool the occupants below

- Close windows and add door foam or brush seals to prevent cool air from leaking outdoors (gaps are shown in Figure 29).

- Set the thermostat to a higher temperature, gradually increasing it over a few months to $74^{\circ} \mathrm{F}$.

ASHRAE states that there is only a $10 \%$ dissatisfaction rate for temperatures between $74^{\circ}-78^{\circ} \mathrm{F}^{61}$. The challenge is creating a culture change where people are encouraged to dress appropriately for external conditions and not expect buildings to be cooled to $\sim 60^{\circ} \mathrm{F}$.



Figure 29. Visible gaps in door at Dededo Senior Center Source: NREL/PIX 18584

${ }^{61}$ ASHRAE Standard 55 - Thermal Environmental Conditions for Human Occupancy. 
Humidity control in hot, humid climates prevents mold growth, damp rot in building structures, and health and comfort problems among occupants. Unfortunately, conventional air conditioners cannot control temperature and humidity independently of one another. ASHRAE recommends a $60 \%$ relative humidity maximum at a temperature setting of $78^{\circ} \mathrm{F}$. Simple actions can be taken to lessen the need for dehumidification within a building, including:

- Do not set thermostats to 'fan on' position as this will blow moist air whether the cooling system is on or not

- Use exhaust fans in bathrooms, utility rooms with dryers, and kitchens to direct moist air outdoors.

Higher-cost options for community buildings like the Dededo Senior Center include measures such as improvements to the air conditioning system or creating a cool roof. Modifications at this level should be done during major renovation as the capital costs will be lower than if it is a stand-alone project.

- When replacing an air conditioning system consider a modern desiccant cooling system, which removes humidity at a lower rate of energy consumption

- Retrofit an existing roof into a cool roof by using reflective materials to lower the heat absorption on the roof.

Desiccant cooling is a technology that is advancing and systems are available on the market. These systems typically use water as a coolant and silica gels or lithium-chloride inside desiccant wheels to dehumidify. There are two types of desiccant systems, either solid or liquid. The solid systems can be utilized with a solar heating system that acts as a heat exchanger, however, these systems often need special design modifications in hot, humid climates. Standard configurations of the desiccant cycle are not typically able to reduce humidity low enough for direct evaporative cooling. Liquid systems have shown higher air dehumidification rates at the same operational temperature as solid desiccant systems.

A cool roof is defined as a roof that has a lower roof temperature than traditional roofs, while the sun is shining. Cool roofs are designed to reflect sunlight and emit heat more efficiently than typical roofs through solar reflectance and thermal emittance. Dark roofs absorb approximately $90 \%$ of solar energy and the temperature on the roof can reach up to $150^{\circ} \mathrm{F}$. Higher roof temperatures increase the internal temperatures, which impacts the demand on the air conditioning system. Light colored roofs, on the other hand, absorb less than $50 \%$ of the solar energy, reducing roof temperature and air conditioning loads.

Cool roof materials vary from coatings that can be rolled, brushed, or sprayed to tiles and shingles. Before any cool roof is applied, the roofing structure and integrity should be checked and leaks or problems should be repaired. Coatings are available in acrylic, silicone, and urethane, as summarized in Table 14. Coating varies by manufacture and improper application can cause flaking. Installers should follow manufacturer-specific recommendations.

Table 14. Summary of Cool Roof Coatings by Type

\begin{tabular}{|c|c|c|}
\hline Coating Type & Properties & Cost \\
\hline Acrylic & $\begin{array}{l}\text { Water based, easy to handle, good adhesion to most } \\
\text { roof types, most commonly used reflective coating, } \\
\text { cures by evaporation, reasonably strong, very sensitive } \\
\text { to weather }\end{array}$ & Moderate \\
\hline Silicone & $\begin{array}{l}\text { Solvent based, typically used for spray polyurethane } \\
\text { roofs, weather very well, weaker tensile strength, good } \\
\text { water resistance }\end{array}$ & $\begin{array}{c}\text { More } \\
\text { expensive }\end{array}$ \\
\hline
\end{tabular}




\begin{tabular}{|l|l|c|}
\hline Urethane & $\begin{array}{l}\text { Solvent based, 3-10 times stronger than acrylic, greater } \\
\text { adhesion to most roof types than acrylic, most cure with } \\
\text { exposure to air, less sensitive to weather, more difficult } \\
\text { to work with }\end{array}$ & $\begin{array}{c}\text { More } \\
\text { expensive }\end{array}$ \\
\hline
\end{tabular}

Tile roofs can be designed as cool roofs by selecting tiles with specific reflectance and emittance qualities. Permanent or unfading tiles are often preferred as they retain their surface properties and can yield better lifetime energy savings. With all cool roofs, maintenance is essential to prevent build-up from pollution, debris deposited by wind and storms, mold or algae growth. Any of these naturally occurring deposits will decrease reflectance, leading to a less effective cool roof.

More information about cool roofs can be found on DOE's website on cool-roof resources ${ }^{62}$.

\section{B.2.1.2 Lighting}

Lighting efficiency could be improved through the use of more efficient technologies and energy conservation techniques. Observations indicated the use of less efficient bulbs/lamps and a lack of sensors or awareness in turning lighting off when daylighting was adequate and did not require the use of additional lighting.

Figures 30-32 are examples of adequate daylighting levels without the need for internal lighting. Figure 30 and Figure 31 are examples of effective daylighting levels without the need for internal lighting, again, on an overcast day. Figure 30 is a photograph of the museum at the Lette of Freedom with the lighting on and Figure 31 is a photograph of the same museum with the lighting switched off. There is no noticeable difference in the light level readings in foot candles (fc) with the lights on or off. When NREL staff entered the museum it was unoccupied and all lighting had been left on.

The hotel lobby in Figure 32 has large windows which, even on an overcast day, allow enough light in the lounge areas of the lobby. The red circles emphasize the lights that are turned on, but are not effective in providing additional lighting. Hotel staff were asked if the lights could be switched off, however their investigation into the situation indicated the lighting system is wired in such a way to prevent isolation of specific banks of lighting. The entire lobby seems to be on the same circuit, which does not facilitate control of lighting during daylight hours.

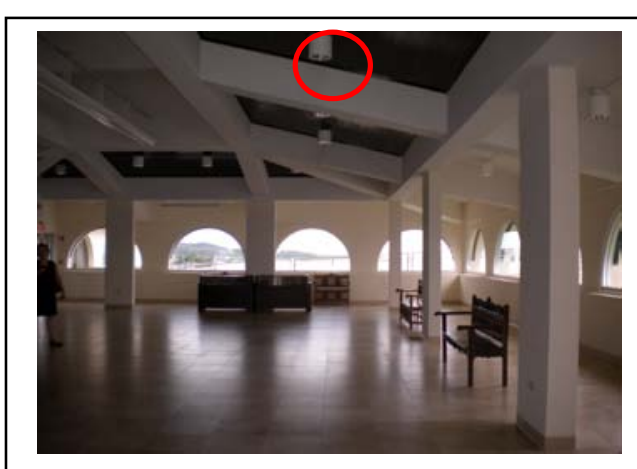

Figure 30. Museum lights off at the Lette of Freedom Source: NREL/PIX 18586
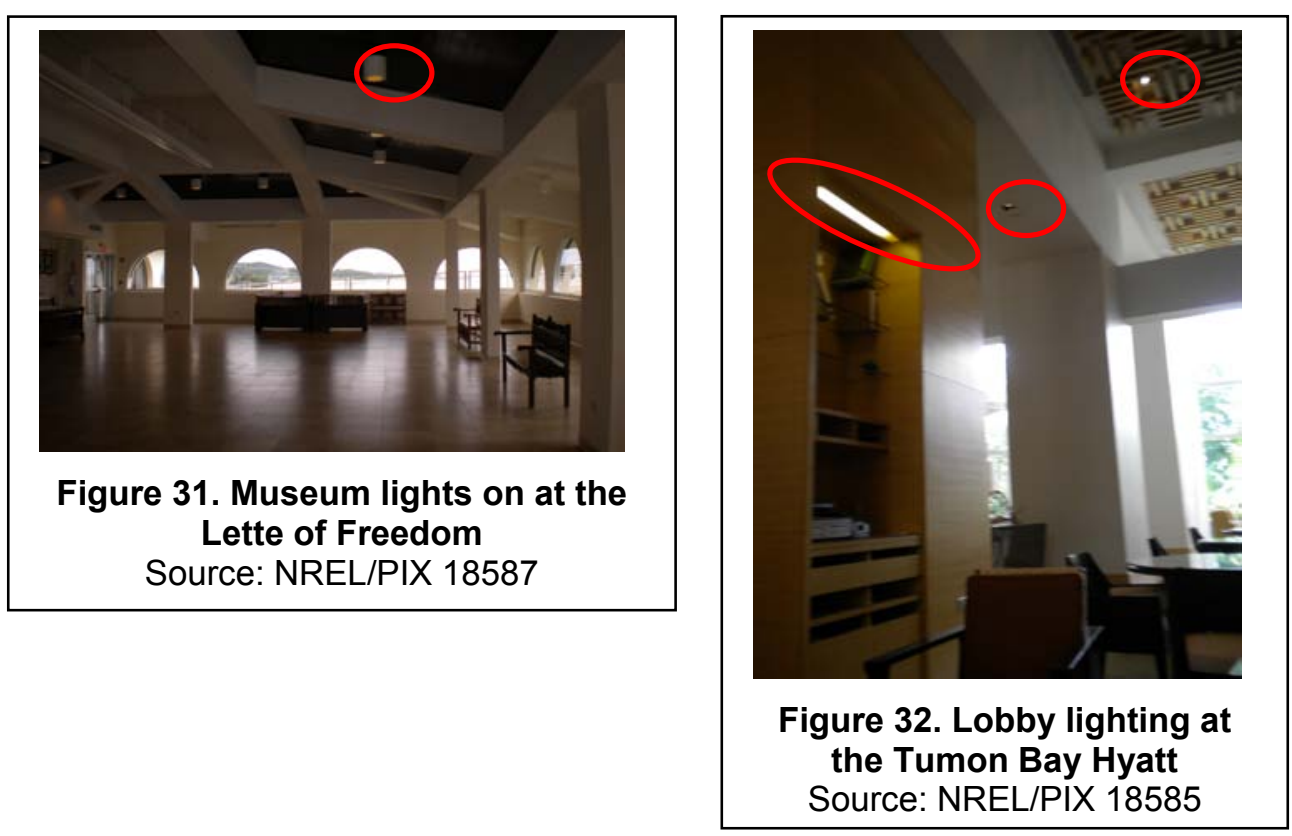

${ }^{62}$ US DOE-FEMP: Cool Roof Resources: http://www1.eere.energy.gov/femp/features/cool_roof_resources.html. 
Hotel lighting would benefit from daylight sensors and wiring that allow lighting to be isolated and switched off when daylighting is adequate. Public areas, such as the museum, would benefit from motion sensors to turn lights on when people approach the museum and switch off if the space is unoccupied.

Effective lighting operation through the use of controls (timers, motion sensors, or daylight sensors) can conserve energy. Lamp type also impacts lighting energy consumption through the light level output and the amount of energy required to generate the light.

Lighting technology has improved significantly in the last decade, evident in the options of higher efficiency lamps. One example is the shift in use of tubular fluorescent lamps from higher wattage lamps to lower wattage lamps. T12 lamps are tubular fluorescent lamps with a larger diameter than either T8 or T5 lamps. The T8 and T5 lamps are lower wattage bulbs. Generally T8 lamps can directly replace T12 lamps, whereas T5 lamps may need an adaptor for the fittings on either end, or an entirely new ballast. Savings of up to $10 \%$ are achievable by replacing a T12 lamp with a T8 lamp in switch-start luminaires.

Other technological advancements have been made in direct replacement bulbs for other lamp types. Compact fluorescent lamps act as direct replacements with lower wattage for incandescent bulbs. LEDs have the highest efficiency of all lamp types, but are not appropriate for all applications. LEDs generate very little heat, but are most effective in directional applications, such as halogen bulb replacements for retail displays. These technologies are becoming less expensive and new applications are being designed at a quick pace. This is a market to monitor for energy efficiency and lighting design within retrofits and new construction.

Table 13 summarizes the recommended lamp types by application, either internal or external and the space that is being used.

Table 13 Recommended Efficient Lamp Types by Space Use

\begin{tabular}{|l|l|l|}
\hline Internal & Space Use & Recommended Lamp Type \\
\cline { 2 - 3 } & Offices & $\begin{array}{l}\text { Triphosphor tubular fluorescent, compact } \\
\text { fluorescent, halogen replacement lamps (LED) }\end{array}$ \\
\cline { 2 - 3 } & Hospitals & $\begin{array}{l}\text { Triphosphor tubular fluorescent, compact } \\
\text { fluorescent, LED }\end{array}$ \\
\cline { 2 - 3 } & Retail & $\begin{array}{l}\text { Triphosphor tubular fluorescent, compact } \\
\text { fluorescent }\end{array}$ \\
\cline { 2 - 3 } & Emergency exit signs & $\begin{array}{l}\text { Metal halide, white sodium, compact fluorescent, } \\
\text { LED, halogen replacement lamps (LED) }\end{array}$ \\
\cline { 2 - 3 } & Parking lots & $\begin{array}{l}\text { High pressure sodium, metal halide, compact } \\
\text { fluorescent }\end{array}$ \\
\cline { 2 - 3 } & Floodlighting & Metal halide, high pressure sodium \\
\cline { 2 - 3 } & Feature lighting & $\begin{array}{l}\text { Metal halide, high pressure sodium, triphosphor } \\
\text { tubular fluorescent, LED }\end{array}$ \\
\cline { 2 - 3 } & Sports facilities & Metal halide \\
\hline
\end{tabular}

\section{B.2.2 Residential}

The NREL team was not able to assess the residential sector in great detail; however this sector may be one where low-cost measures can be implemented easily through an awareness campaign in each village. 
Figure 33 is one example of the type of housing found on island. Interviews on-island indicated a general lack of energy awareness despite high monthly electricity bills.

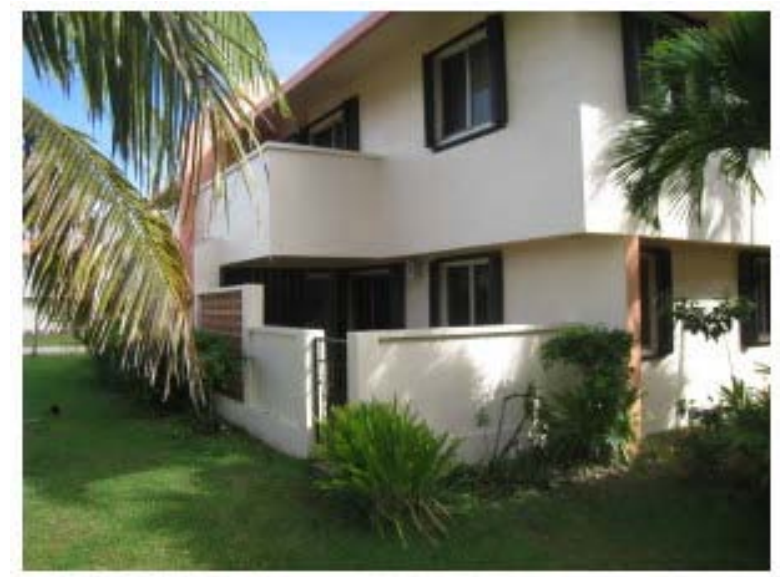

Figure 33. Residential housing in Dededo Source: NREL/PIX 18583

In Guam the highest energy consumption in the residential sector is water heating, followed by air conditioning, and household appliances.

Areas of improvement suggested by island residents during the October 2010 site visit included increasing knowledge of energy conservation within the construction industry. Working with local architects to improve standard building practices, reviewing the building code for energy efficiency specifications and ensuring only energy-efficient equipment and appliances are imported to Guam would contribute to the overall conservation on island.

- Construction and design practices that would be beneficial include using appropriate insulating and reflective building materials (while avoiding reflecting sunlight and heat to neighboring buildings), utilizing external window shading to prevent solar gain through glazing, installing air conditioning systems with an efficient SEER, and installing lighting systems with higher efficiencies.

- Controlling the electrical equipment imported to Guam is another area that would be beneficial. If the industry specified an efficiency standard of equipment and appliances on-island, greater efficiency would result.

While construction improvements may be possible through the USDA's Rural Development Housing and Community Facilities Program ${ }^{63}$ or increasing energy efficiency specifications within the tropical island building code, there are basic measures that can be implemented by residents and communities.

An awareness campaign could be carried out through the local schools and village mayor's offices to encourage residents in each village to reduce energy consumption. Basic measures, such as switching off lights and air conditioners when they're not being used, raising thermostat temperatures on air conditioners, and switching to more efficient light bulbs and appliances, are all actions that can be taken within communities. Teaching children to be more energy conscious in schools is often an effective approach to reducing energy consumption within homes. Friendly competitions could be held between each village and school to encourage implementation. One option is to pilot such a program in Dededo, where the mayor and staff are enthusiastic about energy conservation and where the population is largest. The potential for energy savings is highest and could also set a precedent among other villages and mayor's offices.

\footnotetext{
${ }^{63}$ http://www.rurdev.usda.gov/rhs/.
} 


\section{B.2.3 Outdoor and Street Lighting}

Outdoor and street lighting does not consume the largest portion of Guam's energy, but there are obvious measures that could be undertaken to reduce this sector of energy consumption.

The NREL team observed that outdoor lighting on buildings and street lights were left on during daylight hours when lighting was not needed. On NAVFAC property a call was suggested to turn off a building's external lighting and island residents confirmed that street lighting control was problematic.



Figure 34. Example of street lighting on during daylight hours in Tumon Bay Source: NREL/PIX 18589

The two measures that would be beneficial to this sector are improving the lamps themselves and improving controls.

- Energy-efficient outdoor lighting is available that will reduce the wattage while providing the same quality of light, but should be chosen for specific applications, as summarized in Table 16.

- Lighting controls should be installed and maintained to either switch lights off during daylight hours, be set for specific operational times through the use of timers or use motion detectors to provide light when movement is detected by humans (or in some cases, animals, depending on the application).

Table 16. Recommended Efficient Lamp Types for Outdoor and Street Lighting

\begin{tabular}{|l|l|l|}
\hline \multirow{5}{*}{ External } & Space Use & Recommended Lamp Types \\
\cline { 2 - 3 } & Street lighting & $\begin{array}{l}\text { Induction lighting could be trialed, LED, high } \\
\text { pressure sodium }\end{array}$ \\
\cline { 2 - 3 } & Farking lots & $\begin{array}{l}\text { High pressure sodium, metal halide, compact } \\
\text { fluorescent }\end{array}$ \\
\cline { 2 - 3 } & Floodlighting & Metal halide, high pressure sodium \\
\cline { 2 - 3 } & Feature lighting & $\begin{array}{l}\text { Metal halide, high pressure sodium, triphosphor } \\
\text { tubular fluorescent, LED }\end{array}$ \\
\cline { 2 - 3 } & Sports facilities & Metal halide \\
\hline
\end{tabular}




\section{B.2.4 U.S. Navy}

The U.S. Navy consumes approximately $20 \%$ of the island's total energy. While this is an area where improvements could be made, NREL has not included recommendations in this study due to the fact that the U.S. Navy has undertaken numerous studies and is currently in the process of implementing energy conservation measures and renewable energy.

All military bases on Guam could benefit the island as a whole by ensuring that energy efficiency is a priority during the proposed military build-up, not only for its own facilities and personnel, but also for the facilities that will accommodate the construction workers who will live on-island during the buildup process.

Temporary housing is often constructed with the intent of dismantling the housing once it is no longer needed, however in many cases temporary housing continues to be used for many decades and becomes more permanent than initially anticipated. As such, the military could influence the island's energy loads by working with contractors to encourage, and where within operational control, specify those additional facilities apply energy efficiency standards.

One area for improvement is temporary housing and water treatment plants. Water treatment is discussed in other areas of this report. 


\section{Renewable Energy}

\section{C.1 Solar PV}

\section{C.1.1 Overview}

This section contains discussion of the site parameters used in the Siting Study. These site parameters were investigated using the best available data and following the methodology described in the next section.

The island of Guam contains approximately 46,800 parcels on 133,900 acres. The northern part of the island is relatively flat and is more developed as compared to the southern part of the island. The island's electricity is generated by a number of relatively small fossil-fuel-burning power plants. GPA electricity is delivered through a transmission and distribution grid consisting of a combination of 115 $\mathrm{kV}, 34.5 \mathrm{kV}$, and $13.8 \mathrm{kV}$ lines.

A suitable site for a solar electric generating facility on Guam would have the following general characteristics in order to enhance the cost effectiveness of the project:

- Adequate unoccupied area (60-80 acres)

- Flat or gradual southerly sloped terrain with minimal vegetative cover

- Close proximity to electrical transmission/distribution lines, access roads, and electrical load centers

- Favorable land-use designation or a clear indication that the land use designation can be changed to accommodate the solar project.

The following sections provide further information on the site parameters used in this analysis.

Land zoned for military use as well as land zoned as conservation was ruled out of the analysis. All other zoning designations were considered to be either suitable or relatively easy to change.

Parcels that are substantially occupied were ruled out of the analysis. It should be noted that the parcel map used is two years old and some parcels have been subdivided since this data was created. Therefore, several large parcels in the analysis below contain a number of residences, but have large areas unoccupied. In cases such as these, the unoccupied areas of the parcel were considered suitable and it is assumed that the subdivided portions of the parcel do not substantially interfere with the potential future use of the unused areas.

R.W. Beck provided footprint information of 60-80 acres per $10 \mathrm{MW}$ plant, which GPA accepted as a target parameter for the basis of this memorandum. Based on this parameter, highly irregularly shaped parcels may not be suitable if their shape prohibits the existence of the 60-acre area. However, for the purposes of the IFB, the minimum size is $5 \mathrm{MW}$.

Relatively flat areas are ideal, but a slope of up to $10 \%$ was considered acceptable for this study. Anything beyond $10 \%$ was considered unacceptable.

Areas with a southern-facing slope aspect are ideal, but any slope between $90^{\circ}$ and $270^{\circ}$ (based on compass degrees) was considered acceptable. Any aspect north of this line was considered unacceptable.

An ideal site has close proximity to access roads. Most if not all of the sites are adjacent to roads that have access to village streets or highways. Thus, in general this site parameter was satisfied by most properties that were evaluated. 
For economic reasons, an ideal site shall be located in close proximity to electrical transmission or distribution lines and also the electrical load center. A $34.5-\mathrm{kV}$ feeder connection to the transmission system could be up to 15 or $20 \mathrm{mi}$. in length without incurring significant voltage drop. A $13.8-\mathrm{kV}$ feeder connection to the distribution system could be up to $2 \mathrm{mi}$. in length without incurring significant voltage drop. The actual voltage drop and energy losses in the feeder line will be dependent on the wire size, circuit length, and line configuration, as well as on the magnitude of the current (amperes) flowing in the line.

Monitory considerations, such as cost of step-up transformers, switching and protective devices, and pole line construction, will also have a significant impact in determining the point of connection and system voltage.

Although GPA's preference is to have the solar power plant connect to the transmission system (34.5 $\mathrm{kV}$ ), there are potential cost and equipment factors that may make a connection to the distribution system more advantageous for certain locations. Potential solar power plant developers will be required to undertake a System Impact Study to analyze the benefits, impacts, and necessary upgrades to the GPA transmission $(34.5 \mathrm{kV})$ or distribution $(13.8 \mathrm{kV})$ systems due to their proposed system(s). Figure 23 shows the existing GPA transmission and distribution systems near the proposed sites that were selected in this study. Additional information on the transmission and distribution systems can be obtained from GPA for other areas of the island, upon request.

\section{C.1.2 Methodology}

The following sections outline the step-by-step methodology used to screen all known parcels on the island. All steps below were undertaken in the GIS software program ArcInfo by ESRI, using the Spatial Analyst toolset.

\section{C.1.2.1 Source Data and Known Data Gaps}

The data used for the analysis in this report was primarily obtained from the following GIS layers:

1. Parcels (Cadastre2007.shp) - last updated March 2007

2. Zoning (ZoneMap_update.shp) - last updated March 2006

3. Digital Elevation Model (ned_35956460_GuamGCS93.shp) - created March 2009.

It should be noted that the parcel layer was obtained through existing Government of Guam GIS databases being used by GWA and other government agencies. This layer is missing lot numbers and ownership information on approximately $11 \%$ of the island due to "holes" in the data. However, these land areas were evaluated for slope and slope aspect and it was found that only two areas contain potential sites (the other "holes" consist of areas that are too steep). These lots are identified by the lot number "L0" and will require further research by any interested developers to determine land ownership and confirm the extents of the parcels because they are not in the currently available Cadastre files.

A total of 46,819 parcels are in the parcel layer, 586 of which were zoned "Military" and one of which was zoned "Conservation." These 587 parcels were removed from consideration, leaving 46,232 parcels, under the following zoning designations:

- Agricultural

- Commercial

- Industrial

- Residential. 
Once inappropriately zoned parcels were eliminated, the remaining parcels were screened to eliminate all parcels less than 60 acres, leaving 134 appropriately zoned parcels. Of these parcels, none were eliminated due to highly irregular shapes/dimensions that made the parcel unusable. The remaining 134 appropriately zoned parcels that were $>60$ acres were of sufficient quantity to eliminate the need to search for parcels smaller than 60 acres. However, it should be noted that additional candidate sites may exist in the form of multiple contiguous parcels smaller than 60 acres. For instance, two contiguous parcels that are each 50 acres (and each matching the necessary slope and aspect criteria) could be joined to create a 100-acre parcel. However, this approach was not utilized for this initial screening.

Next, the 134 remaining parcels were placed into Tiers using the screening criteria discussed below (occupancy, percent of slope, and aspect of slope). Tier 1 represents parcels that appear to be the best suited for the intended purposes. Tier 2 represents parcels that have some problems, but are generally well suited according to most screening criteria. Tier 3 represents parcels that appear to have fatal flaws (such as being primarily occupied).

Of the 134 parcels remaining for consideration, many were occupied. Occupied parcels were divided into two categories: primarily occupied and minimally occupied. Minimally occupied parcels may have included large tracts of land with residential or other uses on their periphery. Primarily occupied parcels were placed into Tier 3. It should be noted that some occupied parcels could have lot line adjustments to move unoccupied portions into combination with neighboring parcels. However, this level of analysis was not considered in this study.

Percent of slope was calculated based on a Digital Elevation Model (DEM) with a 100-foot resolution. This means that elevation data for the entire island was divided into discrete cells, each consisting of 10,000 square feet (100' $\left.\mathrm{x} 100^{\prime}\right)$. This DEM was used to generate each cell's slope through the following process:

1. The average elevation of each cell is compared to the eight cells surrounding it

2. The degree of change in elevation from the cell to its immediate neighbors is determined

3. An average slope value (in \%) is assigned to the cell based on this degree of change in elevation.

In this way, an average slope was calculated for each 10,000 sf block of land on the island. All cells with a slope value great than $10 \%$ were symbolized, while all cells with a slope value of $10 \%$ or less were not symbolized. The result is a Percent of Slope layer in which areas that are too steep (according to the site parameter criteria established above) are shaded red.

All parcels were evaluated to identify contiguous areas internal to the parcel that were at least 60 acres and had a slope value of $10 \%$ or less. Parcels that did not meet these criteria were placed into Tier 3.

The same DEM referenced above was used to generate each cell's aspect through a similar process as was used to calculate percent of slope. All cells with a northerly aspect were symbolized, while all cells with a southerly aspect were not symbolized. The result is an Aspect of Slope layer in which areas in which the slope is at the wrong aspect (according to the site parameter criteria established above) are shaded yellow.

When the Aspect of Slope layer is overlaid on the Percent of Slope layer, the result is as follows: areas that are too steep are shaded red, areas that are at the wrong aspect are shaded yellow, while areas that are both too steep and at the wrong aspect are shaded orange.

All parcels were evaluated to identify contiguous areas internal to the parcel that were at least 60 acres and had the appropriate slope aspect. Slope aspect was not weighed as heavily as percent of slope. 
Therefore, many parcels with the wrong slope aspect were permitted into Tiers 1 and 2, as long as the slope percent was acceptable.

For the Tier 1 parcels, distance to roadway was calculated and recorded.

For the Tier 1 parcels, distance to the nearest power transmission or power distribution lines was calculated and recorded. For an overview of Tier 1 Parcels, see Figure 35. 


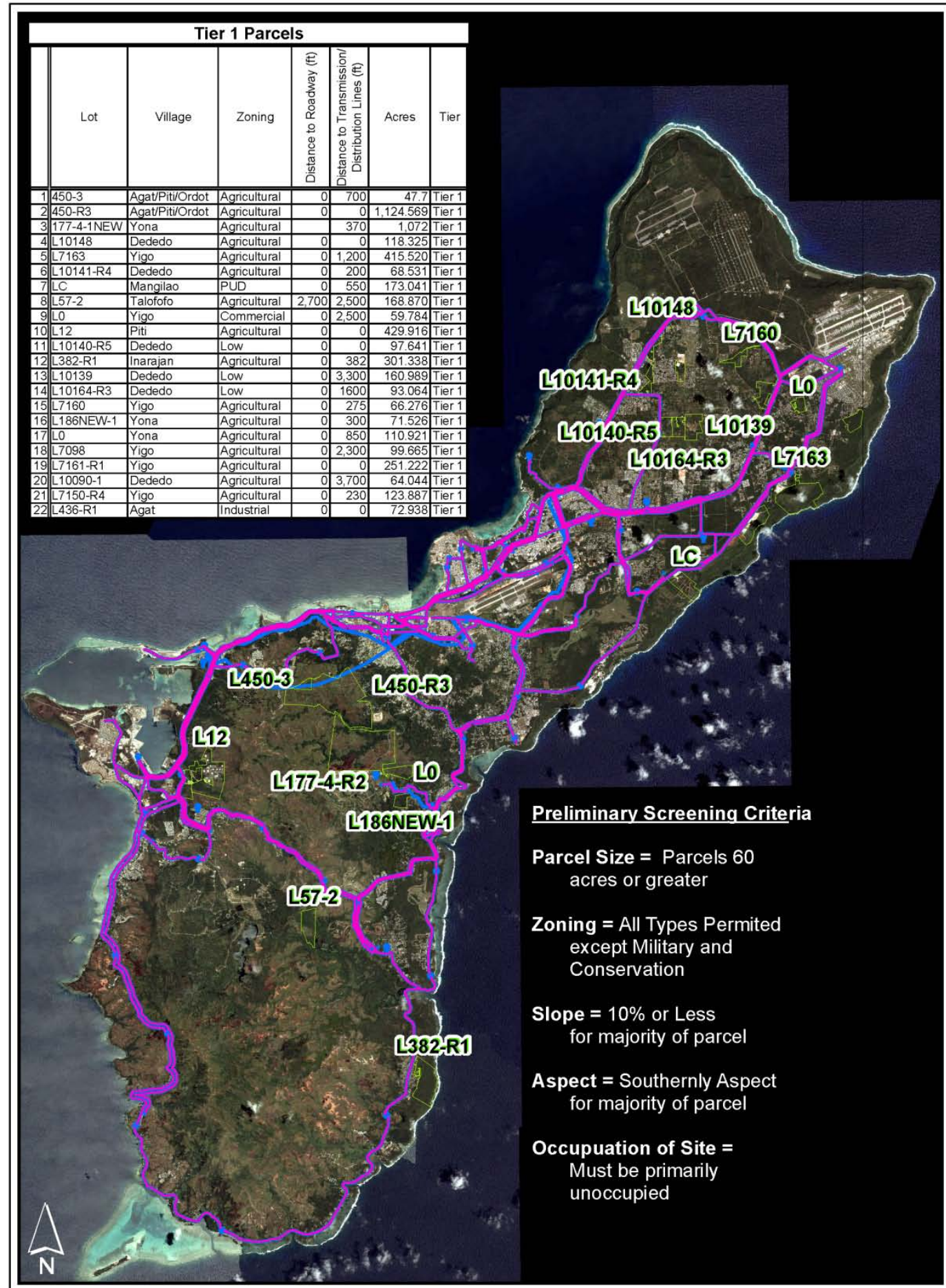

\section{Solar Site Suitability Preliminary Screening}

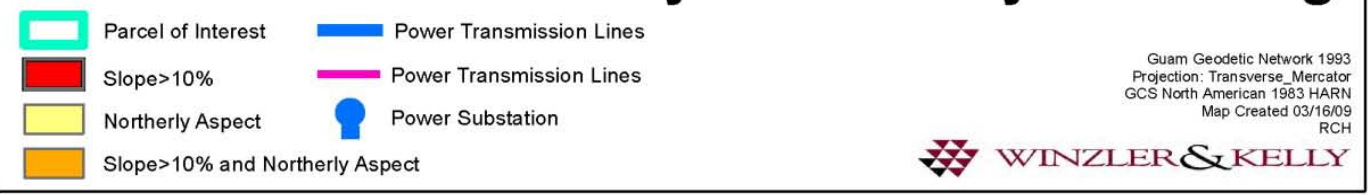

Figure 35. Overview of Tier 1 parcels Source: GPA

\section{C.1.3 Top Seven Parcels}

The top seven parcels from Tier 1 identified during this study are shown in Table 17. The third column is an estimate of the total amount of the array output at a conservative (relatively low) value for the array 
density, and the fourth column is an estimate at an optimistic (relatively high) value. Assuming every acre of every lot could be populated with PV modules, the potential for solar PV could range from 315 MW to $631 \mathrm{MW}$. What remains to be done now is to do field assessments of each site to determine how many acres of each site can actually accept solar arrays.

Table 17. Top Seven Sites Identified for Solar PV

\begin{tabular}{cccc} 
Lot Number(s) & Total Size & $\begin{array}{c}\text { 100-kW / acre } \\
\text { kW PV }\end{array}$ & $\begin{array}{c}\text { 200-kW / acre } \\
\text { kW PV }\end{array}$ \\
\hline L450-R3 & 1,125 & 112,450 & 224,900 \\
L177-4-R2 & 1,072 & 107,200 & 214,400 \\
L7163 & 416 & 41,550 & 83,100 \\
L10140-R5 and & 191 & 19,070 & 38,140 \\
L10164-R3 & 169 & 16,890 & 33,780 \\
L57-2 & 111 & 11,090 & 22,180 \\
L0 & 72 & 7,150 & 14,300 \\
L186NEW-1 & 3,154 & 315,400 & 630,800
\end{tabular}

The remainder of this section briefly describes these seven parcels.

\section{Parcel L57-2}

This parcel is located roughly in the center of the South Island.

\section{Advantages}

- Large area with gradual slope and favorable aspect

- The land is largely undeveloped

- Reasonably close proximity to:

- Electrical transmission/distribution lines

- Access road

- Electrical loads

\section{Disadvantages}

- Southern portion of parcel appears to have varied topography, including some areas with slope greater than $10 \%$ and northerly aspect

- Parcel appears to be heavily forested

- Not as close to electrical infrastructure, roads, and electrical loads as L7163, LO, or L186NEW-1

\section{Parcel L177-4-R2}

This parcel is located in the central part of the island.

\section{Advantages}

- Very large parcel

- The land is largely undeveloped

- Reasonably close proximity to:

$\circ$ Electrical transmission/distribution lines

- Access road

- Electrical loads 
- Substantial portions of parcel appears to have varied topography, including some areas with slope greater than $10 \%$ and northerly aspect

\section{Parcel L186NEW-1}

This parcel is located at roughly mid latitude on the island close to the Eastern shore in close proximity to Parcel LO, which is described above.

Advantages

- Close proximity to Parcel LO

○ Parcels could be combined into one large project site

- Close proximity to:

○ Electrical transmission/distribution lines

- Access road

Disadvantages

- Electrical loads

- Parcel appears to have varied topography, including some areas with slope greater than $10 \%$ and northerly aspect

- Some structures do exist along the southern edge of the parcel

- Parcel appears to be heavily forested

\section{Parcel L450-R3}

This parcel is located in the central part of the island.

Advantages

- Very large parcel

- The land is largely undeveloped

- Near the Ordot Landfill

- Reasonably close proximity to:

- Electrical transmission/distribution lines

- Access road

- Electrical loads

\section{Disadvantages}

- Substantial portions of parcel appears to have varied topography, including some areas with slope greater than $10 \%$ and northerly aspect

\section{Parcel L7163}

This parcel is located on a bluff on the North Eastern shore of the Island.

\section{Advantages}

- Large area with a high percentage of flat or gradually sloped land

- Close proximity to:

- Electrical transmission/distribution lines

- Access road

- Electrical loads

- A significant portion of the property appears to have been cleared previously

- The land is undeveloped (i.e. no structures exist on parcel)

Disadvantages

- Potential impacts to recreation 


\section{Parcel LO}

This parcel is located at roughly mid latitude on the island close to the Eastern shore.

Advantages

- Large area with a high percentage of flat or gradually sloped land

- Close proximity to:

- Electrical transmission/distribution lines

- Access road

- Electrical loads

- A significant portion of the property appears to have been cleared previously

- The land is undeveloped (i.e. no structures exist on parcel)

Disadvantages

- None apparent

\section{Parcels L10164-R3 \& L10140-R5}

These adjacent parcels are located roughly in the center of the North Island.

\section{Advantages}

- Together, these parcels have a reasonably large area with gradual slope and favorable aspect

- Close proximity to:

○ Electrical transmission/distribution lines

O Access road

- Electrical loads

Disadvantages

- Parcels both have some residential and agricultural development on them

- Parcel L10164-R3 does have some area that is greater than 10\% slope.

$\circ$ However, this area is southerly facing.

- The undeveloped area on these parcels appears to be moderately forested

- Closest proximity to electrical infrastructure appears to be to either transmission or distribution lines, not both.

- Data was not sufficient to make a further determination on this point

\section{C.1.4 Summary}

Based on this preliminary study it appears that there are numerous properties available on Guam that could support a $10 \mathrm{MW}$ solar power plant. However, potential developers must include provisions to perform a System Impact Study for any potential site they may consider. This should include a review of the adjacent GPA transmission and/or distribution systems, load centers, line losses, proximity to roads and improvements that may be required to satisfy other aspects of the IFB.

\section{C.2 Wind Technology}

\section{C.2.1 Previous Wind Assessment Activities}

Both GPA and the U.S. Navy have conducted wind development assessments on Guam. In a study conducted by DNV-Global Energy Concepts for GPA, two viable wind sites have been identified; the larger one is in the area of Cotal, along the Cross Island Road (HWY 17). The second site was in the area of Pulantat.

The Cotal area could support approximately 10 large wind turbines along two ridges, with a total capacity of approximately $20 \mathrm{MW}$. The site has good road access, is close to a $34.5 \mathrm{kV}$ transmission line, and is within several miles of a substation. The site was reviewed during the NREL island visit and proved to be a good location. The turbines would be installed upwind from several homes and a larger 
potential development area. The site sits directly south of the Leo Palace Resort and although not close, will be clearly visible from the resort. The elevation of the site is around $200 \mathrm{~m}$, which puts it only approximately $50 \mathrm{~m}$ lower that the island high spots and approximately $3 \mathrm{mi}$. from the U.S. Navy met mast, which shows an annual wind speed in the area of $8 \mathrm{~m} / \mathrm{s}$. Land in this area is primarily owned by the Department of Agriculture with several smaller private holdings. GPA has been working to implement a $50 \mathrm{~m}$ met tower at this site to allow detailed wind resource characterization and the development of project economics. The initial attempt to compete a RFP for the installation was hampered by the requirement of any measurement equipment being able to withstand a Class $\mathrm{V}$ typhoon. Due to the very high resulting costs proposed, the RFPs had to be canceled and next steps assessed.

The Pulantat site sits very close to the Leo Palace Resort and could support approximately five wind turbines with a total capacity of around $10 \mathrm{MW}$. This site is much more complicated due to proximity to local residents and facilities, local topography, the airport, and other communications/radar facilities. The site also sits on private land holdings and is lower in elevation then the Cotal site. This site is considered secondary to the Cotal location.

GPA has also conducted a long term wind measurement program as part of its air abatement activities. The met tower is a nominal $60 \mathrm{~m}$ tower and installed near the Cabras-Pili power plant. The site is generally sheltered and is on the leeward side of the island, so likely will not provide a good correlation for wind project assessment.

The U.S. Navy, through an Interagency Agreement between the Naval Facilities Engineering Service Center (NFESC) and NREL, has been funding a wind resource assessment on U.S. Navy lands. As part of this project one $60 \mathrm{~m}$ met tower was installed on the western boundary of the Ordnance Annex just below Mt. Alifan. This measurement station was installed in September 2008 and although it would be very difficult, if not impossible, to install wind turbines in this area due to environmental impacts, it does provide a very good free wind speed reference site for any additional wind assessment programs.

The data collected thus far shows it to be a very good Class 5 resource with a mean wind speed in the region of $7.9 \mathrm{~m} / \mathrm{s}$. A monthly plot of wind speed is shown in Figure 36. The winds peak midday and come primarily from the east and south by southwest, as shown in Figure 37. Since the installation of turbines along the ridge is not likely in the near term, the U.S. Navy has considered installing turbines at other locations, such as the U.S. Navy port breakwater, for community-scale wind projects of one to three multi-MW wind turbines. The location and assessment status of these projects is not currently known but do represent additional installed wind capacity on the island. 


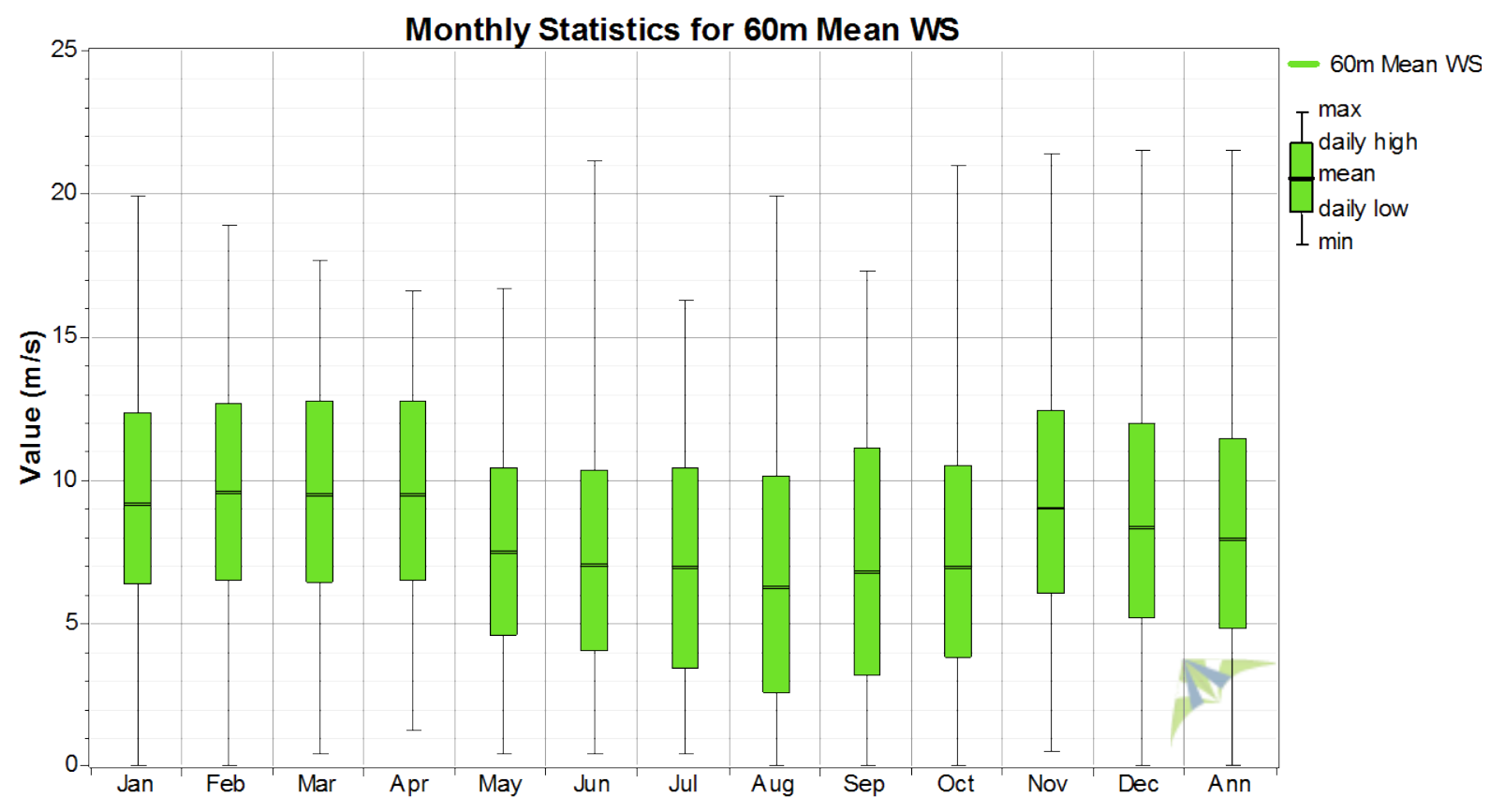

Figure 36. Boxplot of mean wind speed at $60 \mathrm{~m}$ for Guam Naval Ordnance (10/1/2008 - 9/30/2010) Source: NREL

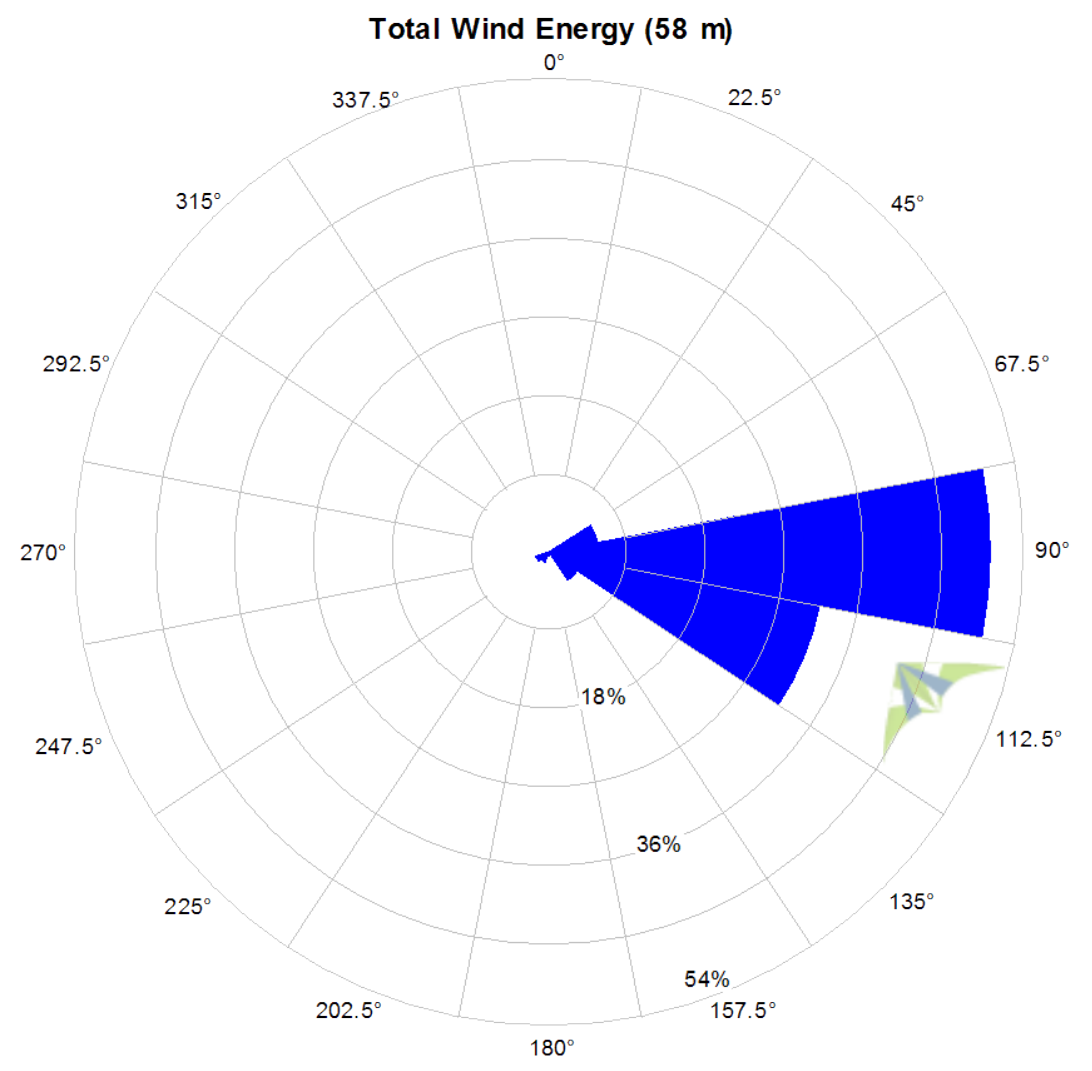

Figure 37. Power density rose for Guam Naval Ordnance (10/1/2008 - 9/30/2010) Source: NREL 
Table 148. Estimated Total Population Increase on Guam from Off-Island (Direct, Indirect, and Induced)

\begin{tabular}{|c|c|c|c|c|c|c|c|c|c|c|c|}
\hline & 2010 & 2011 & 2012 & 2013 & 2014 & 2015 & 2016 & 2017 & 2018 & 2019 & 2020 \\
\hline \multicolumn{12}{|l|}{ Direct DoD Population $^{1}$} \\
\hline $\begin{array}{l}\text { Active Duty Marine } \\
\text { Corps }\end{array}$ & 510 & 1,570 & 1,570 & 1,570 & 10,552 & 10,552 & 10,552 & 10,552 & 10,552 & 10,552 & 10,552 \\
\hline $\begin{array}{l}\text { Marine Corps } \\
\text { Dependents } \\
\end{array}$ & 537 & 1,231 & 1,231 & 1,231 & 9,000 & 9,000 & 9,000 & 9,000 & 9,000 & 9,000 & 9,000 \\
\hline Active Duty Navy ${ }^{2}$ & 0 & 0 & 0 & 0 & 0 & 0 & 0 & 0 & 0 & 0 & 0 \\
\hline Navy Dependents & 0 & 0 & 0 & 0 & 0 & 0 & 0 & 0 & 0 & 0 & 0 \\
\hline Active Duty Army & 0 & 50 & 50 & 50 & 50 & 630 & 630 & 630 & 630 & 630 & 630 \\
\hline Army Dependents & 0 & 0 & 0 & 0 & 0 & 950 & 950 & 950 & 950 & 950 & 950 \\
\hline $\begin{array}{l}\text { Civilian Military } \\
\text { Workers }\end{array}$ & 102 & 244 & 244 & 244 & 1,720 & 1,836 & 1,836 & 1,836 & 1,836 & 1,836 & 1,836 \\
\hline $\begin{array}{l}\text { Civilian Military Worker } \\
\text { Dependents }\end{array}$ & 97 & 232 & 232 & 232 & 1,634 & 1,745 & 1,745 & 1,745 & 1,745 & 1,745 & 1,745 \\
\hline $\begin{array}{l}\text { Off-Island Construction } \\
\text { Workers (DoD Projects) }\end{array}$ & 3,238 & 8,202 & 14,217 & 17,834 & 18,374 & 12,140 & 3,785 & 0 & 0 & 0 & 0 \\
\hline $\begin{array}{l}\text { Dependents of Off-Island } \\
\text { Construction Workers } \\
\text { (DoD Projects) }\end{array}$ & 1,162 & 2,583 & 3,800 & 3,964 & 4,721 & 2,832 & 1,047 & 0 & 0 & 0 & 0 \\
\hline Direct DoD Subtotal & 5,646 & 14,112 & 21,344 & 25,125 & 46,052 & 39,685 & 29,545 & 24,713 & 24,713 & 24,713 & 24,713 \\
\hline \multicolumn{12}{|c|}{ Indirect and Induced Population } \\
\hline $\begin{array}{l}\text { Off-Island Workers for } \\
\text { Indirect/Induced Jobs }{ }^{3}\end{array}$ & 2,766 & 7,038 & 11,773 & 14,077 & 16,988 & 12,940 & 6,346 & 4,346 & 4,346 & 4,482 & 4,482 \\
\hline $\begin{array}{l}\text { Dependents of Off-Island } \\
\text { Workers for } \\
\text { Indirect/Induced Jobs }\end{array}$ & 2,627 & 6,685 & 11,184 & 13,373 & 16,138 & 12,293 & 6,028 & 4,372 & 4,372 & 4,413 & 4,413 \\
\hline $\begin{array}{l}\text { Indirect/Induced } \\
\text { Subtotal }\end{array}$ & $\mathbf{5}, 393$ & 13,723 & 22,957 & 27,450 & 33,126 & 25,233 & 12,374 & 8,718 & 8,718 & 8,895 & 8,895 \\
\hline Total Population & 11,038 & 27,835 & 44,301 & 52,575 & 79,178 & 64,918 & 41,919 & 33,431 & 33,431 & 33,608 & 33,608 \\
\hline
\end{tabular}

Notes: ${ }^{1}$ DoD population includes military personnel, DoD civilian workers and dependents from off-island.

${ }^{2}$ The Navy rows do not include increases from the transient presence of aircraft carrier crew with its CSG.

${ }^{3}$ Population figures do not include Guam residents who obtain employment as a result of the proposed actions.

Source: Guam and CNMI Military Relocation Final EIS (July 2010), Pg. ES-.8 